UNIVERSIDADE DE SÃO PAULO

FACULDADE DE FILOSOFIA, LETRAS E CIÊNCIAS HUMANAS

DEPARTAMENTO DE FILOSOFIA

PROGRAMA DE PÓS-GRADUAÇÃO EM FILOSOFIA

\title{
UMA RECONSTRUÇÃO RACIONAL DA CONCEPÇÃO UTILITARISTA DE BENTHAM:
}

Os Limites entre a Ética e a Legislação

Maria Cristina Longo Cardoso Dias

São Paulo 


\title{
UMA RECONSTRUÇÃO RACIONAL DA CONCEPÇÃO UTILITARISTA DE BENTHAM:
}

\author{
Os Limites entre a Ética e a Legislação
}

\section{Maria Cristina Longo Cardoso Dias}

Dissertação apresentada ao Programa de PósGraduação da Faculdade de Filosofia, Letras e Ciências Humanas da Universidade de São Paulo, para a obtenção de título de mestre em Filosofia.

Orientador: Prof. Doutor José R. Novaes Chiappin

São Paulo

2006 
Aos meus pais Daguzan e Wanda. 


\section{AGRADECIMENTOS}

Ao meu orientador professor José Raimundo Novaes Chiappin, pelas idéias inovadoras e pelos debates efetuados comigo, ao longo de todo este trabalho.

Ao professor Marco Antonio Zingano e à professora Maria das Graças pelos ensinamentos filosóficos.

Ao professor Caetano Ernesto Plastino, por acompanhar-me, ainda que indiretamente, desde a minha entrada no curso de filosofia.

Ao Departamento de Filosofia da FFLCH/USP e aos amigos que lá fiz.

À professora Silvia Maria Schor, por estimular o debate de concepções econômicas alternativas à Neoclássica.

Aos meus pais pelo apoio em tudo que realizei na minha vida.

Aos queridos André, Guilherme e Rejane, pelo apoio direto no decorrer de todo este trabalho.

A todos os meus amigos e aos meus irmãos que, indiretamente, contribuíram para a finalização deste trabalho. 
À CAPES que me forneceu condições materiais para a minha dedicação exclusiva à esta tese. 


\section{Resumo}

O Objetivo deste trabalho é estabelecer os limites entre a ética e a legislação, a partir da concepção teórica de Jeremy Bentham. Para atingir este objetivo, será efetuada uma reconstrução racional de seu sistema teórico, utilizando a Metodologia da Teoria da Ciência [MTC] e a Metodologia dos Programas de Pesquisa Científicos.

Uma vez feita a reconstrução racional da concepção teórica de Bentham, tencionase demonstrar, por meio de elementos de sua sistemática, que o próprio princípio da utilidade estabelece a linha divisória entre ambos os campos. Ou seja, é o princípio da utilidade que ditará o raio de ação da lei e da ética, bem como seus limites.

Será possível compreender que estabelecer as fronteiras entre a ética e a legislação, a partir do princípio de utilidade, significa, em última instância, fazer uma análise do balanço envolvendo prazer e dor. Em linguagem atual, pode-se dizer que este exame será aquele em termos de custo e benefício, pois, em muitos casos, a elaboração de legislação e aplicação de punição a determinadas transgressões tendem a gerar custos sociais mais elevados do que o benefício auferido. Em outras palavras, para alguns tipos de transgressão a legislação não deverá ser aplicada, mas apenas as regras da ética.

Palavras-chave: Bentham, Reconstrução Racional, Ética, Legislação, Utilitarismo. 


\begin{abstract}
The aim of this work is to determine the limits between ethics and legislation through the theoretical conception of Jeremy Bentham. In order to achieve this aim, it will be done a rational reconstruction of his theoretical system, using The Methodology of Science Theory [MTC] and The Methodological of Scientific Research Programmes.

Once done the Rational Reconstruction of the Bentham's Theoretical Conception, it will be demonstrated (through elements of his system) that the principle of utility indicates the limits between these fields. It means that, this principle will dictate the scope and the limits between the legislation and ethics.

It will be possible to comprehend that establishing boundaries between ethics and legislation, through the principle of utility, means setting a balance analysis involving pleasure and pain. In contemporary language, it can be said that this examination will be done in terms of cost and benefit. The elaboration of legislation and the application of punishment to certain transgressions tend to generate social costs more elevated than the created benefit. In other words, the legislation shall not be applied to some kinds of transgressions, but only the rules of ethics.
\end{abstract}

Key words: Bentham, Rational Reconstruction, Ethics, Legislation, Utilitarianism. 


\section{Sumário}

$\begin{array}{ll}\text { Resumo } & 6\end{array}$

$\begin{array}{ll}\text { Abstract } & 7\end{array}$

\section{Introdução}

1.1 Considerações Gerais 12

1.2 A Eleição da Metodologia Utilizada 15

1.3 A Relação dos Programas de Pesquisa de Lakatos com a Metodologia da Ciência $[\mathrm{MTC}]$ de Chiappin

2. Uma Reconstrução Racional da Teoria Utilitarista de Bentham

2.1 Introdução: Objetivos do Capítulo 27

2.2 O Núcleo da Concepção Utilitarista de Bentham 29

2.3 A Lógica da Concepção de Bentham: Sua Metodologia. 39

\section{O Conceito de Utilidade de Bentham}

3.1 Introdução: Objetivos do Capítulo 
3.3 Algumas interpretações do princípio de utilidade de Bentham: Uma possível solução para o problema da minoria

3.4 Princípio da Utilidade e a Interação entre indivíduos: Benevolência convergente com o princípio da utilidade.

3.5 O Princípio da Utilidade como recurso para a construção de um meio-termo entre o Conservadorismo e a Anarquia: Construção de uma forma de Governo ou Estado

3.6.1 Aplicação do princípio da utilidade como resposta ao contrato original e à manutenção de promessas.

3.6.2 Aplicação do princípio da utilidade para a construção da regra da maioria de Bentham:

a solução do problema do meio-termo entre conservadorismo e anarquia

3.7 O princípio da utilidade e seus subprincípioss:

As relações da moral com a ética

3.8 A Imoralidade como causa da aplicação incorreta do princípio da utilidade 130

\section{Os Limites entre a Ética e a Legislação}


4. 1 Introdução: A Apresentação do Problema

4.2 A Concepção de Legislação segundo Bentham

4.2.1 O método de construção de Bentham: como construir um corpo teórico científico 142

4.2.2 Atos abrangidos pela lei: classes de ofensas.

4.3 A Concepção de Ética de Bentham

4.4 Solução do Problema: A Demarcação da Fronteira entre Ética e Legislação

4.4.1 Breve distinção entre a ética e a legislação

4.4.2 Casos em que não cabe punir 
Capítulo I

Introdução 


\subsection{Considerações Gerais}

Esta investigação tem por objetivo reconstruir, racionalmente, o sistema teórico de Jeremy Bentham, para entender a demarcação entre ética e a legislação dentro do sistema deste autor. Assume-se como hipótese, aqui, que esta teoria constitui a primeira teoria do programa de pesquisa do utilitarismo, sendo, por esta razão, escolhida como ponto de partida para análise.

Toda sua teoria moral e da legislação é sustentada pelo princípio da utilidade, exposto por Bentham da seguinte forma:

"[...] Por princípio da utilidade entende-se aquele princípio que aprova ou desaprova qualquer ação, segundo a tendência que tem a aumentar ou a diminuir a felicidade da pessoa cujo interesse está em jogo, ou, o que é a mesma coisa em outros termos, segundo a tendência a promover ou a comprometer a referida felicidade. Digo qualquer ação, com o que tenciono dizer que isto vale não somente para qualquer ação de um individuo particular, mas também para qualquer ato ou medida de governo [...]". Ou, em outros termos, o princípio da utilidade é exposto da seguinte forma: "[...] O princípio que estabelece a maior felicidade de todos aqueles cujo interesse está em jogo, como sendo a justa e adequada finalidade da ação humana, e até a única finalidade justa, adequada e universalmente desejável: da ação humana, digo, em qualquer situação ou estado de vida, sobretudo na condição de um funcionário ou grupo de funcionários que exercem os poderes do governo [...]”. (Bentham, 1789, p.10). 
Este princípio reconhece a sujeição do gênero humano ao domínio de dois senhores soberanos, a saber: o prazer e a dor e os coloca como fundamento desse sistema, cujo objetivo consiste em construir o edifício da felicidade de uma comunidade.

Bentham, ancorado em sua teoria, e indignado com a falta de fundamentos da legislação de seu país, no século XVIII, procurou aplicações práticas dedicando-se, sobretudo, às reformas da legislação, codificação das leis (a fim de que pudessem ser compreendidas por qualquer indivíduo), ao aperfeiçoamento do sistema penitenciário e ao desenvolvimento do regime democrático através da introdução do sufrágio universal. Esta necessidade de aplicações de seu sistema teórico traz importante esclarecimento a respeito do contorno prático que é dado por ele à sua obra.

Toma-se como hipótese que o princípio de utilidade, apresentado por Bentham, norteará, com algumas variações, todo programa de pesquisa utilitarista iniciado a partir de fins do século XVIII. Assim, eleita, por hipótese, o primeiro sistema teórico utilitarista como sendo a de Bentham, far-se-á uma reconstrução racional de sua doutrina. Esta reconstrução utilizará elementos metodológicos de Chiappin e Lakatos, conforme se verá na próxima seção. A reconstrução racional terá como objetivo principal, no presente trabalho, entender as relações que se estabelecem entre a ética e a legislação, no utilitarismo de Bentham.

Tendo em vista estes fatores, o trabalho é dividido nos seguintes capítulos:

a) Capítulo I: Introdução.

b) Capítulo II: Reconstrução racional da teoria utilitarista de Bentahm, com utilização dos instrumentos metodológicos descritos no capítulo I.

c) Capítulo III: Aplicações e interpretações do princípio de utilidade.

d) Capítulo IV: Os limites entre a ética e a legislação, dentro de sua obra. 
A divisão deste trabalho nestes capítulos justifica-se, pois, primeiramente, é necessário apresentar os instrumentos metodológicos e a noção de racionalidade aqui utilizada, para depois efetuar-se a reconstrução da teoria utilitarista de Bentham. Esta reconstrução se faz necessária para que se tenha claro o núcleo ou Metafísica de sua teoria (teses epistemológicas, axiológicas e ontológicas), bem como sua metodologia de operacionalização do núcleo, com vistas a entender uma série de afirmações e interpretações que são feitas neste trabalho.

Após a reconstrução racional da teoria de Bentham, levando sempre em conta as teses epistemológicas, axiológicas e ontológicas identificadas, assim como sua metodologia, torna-se necessário problematizar aplicações e implicações da metodologia analisada. Isto será feito no capítulo terceiro do presente trabalho, a partir de análise mais detalhada do princípio de utilidade do autor.

Finalmente, reconstruídos, apresentados, interpretados e discutidos os principais elementos da teoria do autor, bem como analisados alguns problemas, aplicações e implicações de seus conceitos e metodologias, parte-se ara entender os limites entre a moral e a legislação dentro da obra de Bentham. O estabelecimento de limites, entre estes dois campos, será feito com o auxílio de todos os recursos e discussões efetuadas nos capítulos precedentes.

Tendo em vista o desenvolvimento desta dissertação, apresentam-se, no próximo tópico, os instrumentos metodológicos a serem utilizados nesta reconstrução racional. 


\section{2- A eleição da metodologia utilizada}

O procedimento para reconstrução racional da primeira teoria do programa de pesquisa do utilitarismo seguirá, no presente trabalho, a Metodologia da Teoria da Ciência [MTC] desenvolvida por Chiappin e alguns recursos da metodologia científica dos programas de pesquisa apresentada por Lakatos. Ou seja, será realizada a reconstrução racional da teoria utilitarista de Bentham, com o auxílio do instrumental metodológico de Chiappin e Lakatos.

A metodologia de Lakatos é caracterizada por uma continuidade que alia diversas teorias possuidoras de um núcleo teórico comum. Esta seqüência unificadora de teorias ${ }^{1}$ como partilhando de um mesmo núcleo teórico são agrupadas, pelo autor, em programas de pesquisa. Os programas de pesquisa partilham de núcleos teóricos rígidos, convencionalmente aceitos, provisoriamente irrefutáveis e assessorados por um cinturão de hipóteses auxiliares.

Como regras metodológicas dos programas de pesquisa encontram-se a heurística positiva e negativa, que funcionam como guia da ciência em seu objetivo de resolver problemas. A heurística positiva é constituída por métodos pelos quais procura-se solucionar problemas, tendo como pressuposições componentes do núcleo teórico. A heurística negativa constitui uma regra que desvia a atenção do cientista do núcleo, buscando dirigir seu foco à elaboração ou refutação da metodologia presente na heurística positiva. Em outros termos, ela funciona como uma proteção do núcleo rígido do programa de pesquisa contra os ataques diretos, que devem ser desviados para a heurística positiva Os programas de pesquisa de Lakatos possuem, assim, os

\footnotetext{
${ }^{1}$ A respeito disto cito Lakatos em Criticism and Growth of Knowledge p. 118: "[...] Let us take a series of theories, $T 1, T 2, T 3, \ldots$ where each subsequent theory results from adding auxiliary clauses to the previous theory in order to accommodate some anomaly, each theory having at least as much content as the unrefuted content of its predecessor $[\ldots] ”$.
} 
seguintes elementos: a) núcleo, b) heurística negativa e c) heurística positiva ou cinturão de proteção do núcleo. Esta metodologia expressa uma maneira racional de reconstruir a ciência.

A vinculação da heurística aos princípios metafísicos que compõem o núcleo rígido, bem como o desenvolvimento e a operacionalização desta idéia de racionalidade, de Lakatos, expressos pelos programas de pesquisa são efetuados de maneira sistemática por Chiappin com sua Metodologia da Teoria da Ciência [MTC].

Trata-se de uma proposta para reconstruir concepções de teorias da ciência e teorias políticas (vistas como um corpo teórico político científico). Esta concepção de racionalidade compõe um sistema de fins, valores, testes, princípios, métodos, critérios e técnicas que pode ser organizado segundo três níveis conectados, quais sejam: a) Metafísico, b) Lógico e c) Histórico.

O nível metafísico, denominado núcleo dos programas de pesquisa ou núcleo de uma concepção teórica, partilha de teses ontológicas, epistemológicas e axiológicas. As teses ontológicas têm por função descrever as características fundamentais da natureza e do mundo real (enumera-se o que de fato existe), as teses epistemológicas encarregam-se de descrever a natureza do conhecimento humano (de que forma é possível conhecer) e as teses axiológicas que fornecem informações acerca dos fins e valores aos quais determinados programas estão vinculados. Estas teses representam o núcleo de teorias em um programa de pesquisa.

Este patamar de análise contém as principais pressuposições da concepção do programa de pesquisa sob investigação, assim como os fins a serem perseguidos pelo programa. Neste nível encontram-se, ainda, as restrições as quais os fins devem ser perseguidos. As restrições são dadas pelos valores que o programa de pesquisa deve partilhar, assim como pela natureza do conhecimento que se pode ter dos fenômenos.

O plano da lógica encontra-se na heurística positiva do programa de pesquisa. Ele apresenta ênfase sobre a descrição dos instrumentos, métodos, técnicas, critérios e regras para 
operacionalizar o núcleo metafísico do programa de pesquisa. Este nível é dividido em metodologia e metametodologia. A metodologia aborda a racionalidade científica, a construção e a aplicação da unidade epistêmica. Ela existe para aplicar o núcleo na solução de problemas práticos. Na metametodologia são discutidas e debatidas as diferentes concepções de sistemas constituídos por sua metafísica e sua metodologia. Nela se encontra a crítica de outras concepções a partir da concepção teórica que se está reconstruindo, os métodos da ciência, os critérios, as regras, argumentos e justificações para sua escolha. O nível da História da Ciência desempenha, também, um papel heurístico, pois sugere componentes no âmbito histórico, contribuindo na escolha e justificação das concepções da ciência.

É importante levar-se em conta que não será efetuada, neste trabalho, uma reconstrução racional do programa de pesquisa do utilitarismo, com todas as teorias pertencentes ao programa. $\mathrm{O}$ que se pretende fazer é reconstruir uma concepção teórica utilitarista, a saber: a de Jeremy Bentham, pois considera-se, por hipótese, que ela constitui a primeira teoria do programa de pesquisa do utilitarismo.

Entretanto, apesar de não ser efetuada a reconstrução racional do programa de pesquisa do utilitarismo, considerando os vários autores pertencentes a ele, elementos de Lakatos estão presentes neste trabalho, pois supõe-se que o núcleo e a heurística do programa de pesquisa do utilitarismo partilhará de, ao menos, algumas teses semelhantes à de Bentham. Além disso, pretende-se em um trabalho futuro, prosseguir a análise sobre teorias utilitaristas para construir o programa de pesquisa desta vertente do pensamento.

Assim, tendo em vista estas breves considerações sobre os programas de pesquisa de Lakatos e sobre sua operacionalização, a partir da concepção de racionalidade proposta por Chiappin [MTC] parte-se para entender de que forma as teorias políticas podem ser reconstruídas com base nestes instrumentos metodológicos científicos. 
A reconstrução racional da ciência pode ser expandida a teorias políticas, pois a partir do século XVII toda estrutura clássica do modo de conceber a construção da ciência é empregada na maneira como erigem-se as teorias políticas. Em outras palavras, há a tentativa, a partir do século XVII de transformar as teorias políticas em obras teóricas científicas, a partir da demonstração de proposições, quer por força do intelecto, como defendiam os intelectualistas clássicos, quer por força dos sentidos, como admitiam os empiristas clássicos.

Toda estrutura do racionalismo clássico do modo de conceber a construção da ciência possui origem na concepção cartesiana de conhecimento. Esta concepção tem como idéia central a noção de que a natureza do conhecimento é a verdade e a certeza. Tomando esta idéia constrói-se todo um modelo de ciência e de teorias políticas para proporcionar decisões conclusivas acerca da verdade ou falsidade das proposições. Por exemplo, Descartes pretendia fazer da metafísica, física, medicina, mecânica e moral um sistema hierarquizado de conhecimento certo. Para Hume a moral é colocada como tendo a mesma natureza ou status da filosofia natural. O objetivo do racionalismo clássico, para Descartes, era o de efetuar demarcação entre o conhecimento e a crença/opinião. $\mathrm{O}$ modelo de conhecimento como conhecimento certo é operacionalizado por um modelo de decisão com certeza que é baseado no modelo geométrico. Neste modelo os fenômenos naturais são, em última instância, fenômenos mecânicos, as faculdades do conhecimento são sempre as mesmas e o método do conhecimento também é único. Este método resolve problemas e apresenta provas por análise e síntese.

O racionalismo clássico que tem como idéia central o conhecimento como certeza e verdade sofre pesadas críticas efetuadas, principalmente, por Hume. O desenvolvimento científico e político, no século XIX, é rico em exemplos que questionam a noção de conhecimento como certeza. A reelaboração de um novo racionalismo, compatível com esse desenvolvimento, continua partilhando da base do racionalismo clássico referente à noção de 
verdade, contudo diferencia-se dele, em alguns aspectos, pois reconhece o caráter hipotético e, portanto, provisório das leis constituintes das teorias científicas e políticas. Esta nova racionalidade propõe a substituição da prova com certeza, pela probabilidade como instrumento de avaliação do conhecimento ${ }^{2}$. Todas as afirmações feitas com base nesta nova idéia devem ser, no mínimo, altamente prováveis. Essa nova perspectiva caracteriza uma nova forma de racionalismo (neo-clássico).

Dentro deste contexto do racionalismo neo-clássico insere-se, também, as teorias políticas que tendem a abandonar a certeza como base da construção de seu corpo teórico, ou seja, o conhecimento e as leis formuladas passam a ser hipotéticos. Isto pode ser sustentado pela verificação de vários autores de teorias políticas do século XIX que abandonam várias idéias tomadas como certeza no século XVII e XVIII. Uma delas refere-se à noção de estado de natureza como sendo responsável por levar à fundação da vida moral e política de uma sociedade. Tal concepção é abandonada pela maioria dos filósofos do século XIX. Não obstante, muitos destes teóricos políticos continuam adotando a idéia de construir um corpo teórico político de caráter científico.

Este, é o caso de Bentham, pois sempre refere-se à legislação e à moral como ciência, como se percebe pelas citações:

"[...] Now for the first time of the matter of a to the subject-matter of this proposed examination and discussion, is given the form and method distinctive branch of art and corresponding science". (Bentham, 1827 p. 2). [...] Ce terme est ici appliqué à la morale, c'est-à-dire, à cette partie du domaine des actions qui ne tombe pas sous l'empire de la législation publique. Comme art, c'est faire ce

\footnotetext{
${ }^{2}$ É importante atentar para o fato de que a base do conhecimento continua sendo a verdade.
} 
qu'il est convenable de faire ; comme science, c'est connaître ce qu'il convient de faire en toute occasion. [...]".'(Bentham, 1834 p.21)

Tendo em vista estas considerações iniciais sobre a construção da política e moral como ciência, bem como a eleição dos instrumentos metodológicos de Chiappin e Lakatos para reconstrução da teoria de Bentham, parte-se para entender a maneira como os instrumentos de Chiappin e Lakatos relacionam-se. 


\subsection{A Relação dos Programas de Pesquisa de Lakatos com a Metodologia da Ciência [MTC] de Chiappin}

O programa de pesquisa (série de teorias), caracterizado por uma certa continuidade que conecta seus membros, é operacionalizado por Chiapppin, organizando um sistema de fins, valores, testes, princípios, métodos, critérios e técnicas que pode ser resumido segundo três níveis conectados, quais sejam: a) Metafísico, b) Lógico e c) Histórico. O nível de análise metafísico encontrar-se-á no núcleo do programa de pesquisa, o nível lógico e histórico farão parte da heurística positiva ou cinturão de proteção do núcleo.

\section{a) Núcleo dos Programas de Pesquisa:}

Todos os programas de pesquisa científica devem ser caracterizados pela sua linha mestra ou núcleo, partilhado por todas as teorias do programa. O núcleo contém conceitos, princípios e pressuposições básicas do programa.

Refinando o conceito de núcleo teórico, com o instrumental de Chiappin, pode-se dizer que seus princípios e pressuposições básicas são classificados em: a) ontologia ou as denominadas teses ontológicas (considerações sobre a natureza do mundo), b) epistemologia ou as denominadas teses epistemológicas (considerações sobre a natureza do conhecimento do 
mundo): e c) axiologia ou teses axiológicas (proposições sobre valores e fins que devem ser perseguidos pela concepção teórica) ${ }^{3}$.

\section{b) Heurística Negativa:}

A heurística negativa constitui uma regra, implícita, que diz que todos os problemas e questões devem ser colocados sob a forma de hipóteses auxiliares e desta forma, serem desviados do núcleo duro do programa de pesquisa. As hipóteses auxiliares, que formam um cinto de proteção ao redor do núcleo, redirecionam o modo Tollens ${ }^{4}$ para estas proposições auxiliares. A heurística negativa mostra que as anomalias ou problemas devem levar a mudanças somente no cinto de proteção de hipóteses auxiliares, não atingindo o núcleo.

São estas hipóteses satélites que sustentarão os testes e serão ajustadas ou substituídas para defender o núcleo duro. Um programa de pesquisa é bem sucedido se leva a um progressivo aumento de problemas (pois faz aumentar teorias explicativas a estas questões) e mal sucedido se leva a uma degeneração da quantidade de problemas (pois o surgimento de novas teorias não é estimulado). Cada dificuldade do programa de pesquisa que é superada constitui em uma vitória para o programa. Junto do aumento progressivo de problemas relacionados à teoria, deve existir um constante aumento de corroboração empírica aos conteúdos adicionais que tratam de dar respostas a estas questões.

\footnotetext{
${ }^{3}$ A subdivisão do núcleo nestes elementos não foi colocada por Lakatos, mas sim por Chiappin J.R.N. A respeito disto o cito em seu artigo Racionalidade, Decisão, Solução de Problemas e o Programa Racionalista: “[...] O nível da metafísica pode, por sua vez, ser decomposto em três sub-níveis: Ontologia [...] Epistemologia [...] e Axiologia $[\ldots] "$.

${ }^{4}$ O Modus tollens consiste na maneira como o falseamento de uma conclusão derivada da teoria acarreta o falseamento do sistema da teoria inteiro. Ex: seja t o sistema e p a conclusão (se p é falsa então t também é). $\mathrm{O}$ contrário não ocorre, ou seja, se p é verdadeiro, não necessariamente t também é verdadeiro.
} 
A idéia de heurística negativa do programa de pesquisa científico racionaliza a adesão aos problemas e a novas teorias, pois as superações à sua linha mestra ocorrem devido ao aumento de hipóteses auxiliares corroboradas de base empírica crescente.

A refutação completa de todo um programa de pesquisa (incluindo o núcleo duro) somente ocorre quando este cessa de antecipar novos fatos, ou seja, não propicia o aumento de teorias que permitam novas previsões e possam ao mesmo tempo ser, em parte, corroboradas por dados empíricos.

c) Heurística positiva: a construção do cinto protetor e a relativa autonomia em relação à ciência teórica:

Conforme expresso acima, além do núcleo e da heurística negativa, os programas de pesquisa são também caracterizados por uma heurística positiva. Esta heurística possui políticas para antecipar possíveis refutações, sendo, por isso, também chamada de cinto protetor. Ela é composta de hipóteses auxiliares com os mais complicados modelos, técnicas e instrumentos capazes de simular a realidade. Isto mostra o quão irrelevantes são as refutações de qualquer variante específica em um programa de pesquisa, pois sua existência é esperada. A heurística positiva existe tanto para prevê-las quanto para dirigi-las.

Dentro dos modelos de teorias, expressos na heurística positiva, pode-se discriminar instrumentos que aparecem freqüentemente ${ }^{5}$ : a) representação: linguagens ou símbolos para

\footnotetext{
${ }^{5}$ Esta discriminação de elementos que aparecem freqüentemente, na heurística positiva, não foi colocada por Lakatos, mas sim por Chiappin J.R.N. A respeito disto o cito em seu artigo Racionalidade, Decisão, Solução de Problemas e o Programa Racionalista p. 185: “[...] Este modelo também denominado modelo I, pode ser descrito como uma estrutura simplificada do conhecimento, um sistema (uma organização de informações, ou ainda dados) que se compõe de três elementos: Base do conhecimento: uma base ou banco de dados [...] Representação: as representações são linguagens ou sistemas simbólicos usados para expressar a base do conhecimento [...] Sistema de interferência: os sistemas de interferências são regras e métodos por meio dos quais extraímos, a partir da base e
} 
expressar o núcleo do conhecimento, bem como técnicas que operacionalizam e servem para ampliar os recursos de solução de problemas do sistema do conhecimento, b) sistema de inferência: regras para extrair outras informações, como analogias, metáforas, deduções e induções, c) metodologia (tem como objeto o programa de pesquisa) é utilizada tanto para a construção das teorias (identificação da estrutura da unidade epistêmica), como para aplicação na solução de problemas, também chamada de sistema operacional (método de construção, método de escolha da melhor entre as instâncias da unidade epistêmica e método de solução que é um conjunto de técnicas para resolver problemas práticos e epistêmicos) e d) metametodologia (tem como objeto a metodologia) que é definida como argumentos para escolher e justificar os métodos e concepções do programa de pesquisa.

Estes modelos para serem aceitos, dentro de novas teorias do programa de pesquisa, além de partilhar do núcleo do programa de pesquisa, devem possuir explicações, dentro da heurística positiva. Ou seja, a nova teoria deve: 1) ter mais conteúdo empírico do que a antiga, isto é necessita prever novos fatos, 2) continuar explicando os fatos que levaram ao sucesso da teoria antiga e 3) parte do seu conteúdo excedido em relação à teoria antiga deve ser verificado, corroborado.

Tendo em vista os instrumentos utilizados na heurística positiva, alguém poderia objetar que nela existiriam argumentos formulados com princípios metafísicos. Realmente, estes estão presentes nesta heurística, contundo, estes princípios são mais flexíveis do que aqueles expressos do núcleo do programa de pesquisa. Ou seja, na heurística positiva, tais proposições são passíveis de serem refutadas.

condições de contorno, outras informações [...] Heurística: conjunto de normas de procedimentos, modelos, técnicas, instrumentos, métodos, regras para resolver os problemas que emergem [...]". 
Todo este aparato que compõe o núcleo, a heurística negativa e positiva, desenvolvido e operacionalizado por Chiappin, constitui um método racional de analisar os programas de pesquisa e é a partir da utilização destes instrumentos que se pretende reconstruir a primeira concepção teórica utilitarista, a saber: a de Jeremy Bentham. 


\title{
Capítulo II
}

\section{Uma Reconstrução Racional da Concepção Utilitarista de}

\author{
Bentham
}

“(...) Nature has placed mankind under the governance of two sovereign masters, pain and pleasure. It is for them alone to point out what we ought to do, as well as to determine what we shall do. They govern us in all we do, in all we say, in all we think: every effort we can make to throw off our subjection, will serve but to demonstrate and confirm it. (...)”.

\section{J. Bentham}

An Introduction to the Principles of Morals and Legislation, p. 1. 


\subsection{Introdução: Objetivos do Capítulo}

Neste capítulo, pretende-se realizar uma reconstrução racional da teoria de Jeremy Bentham, empregando a Metodologia da Teoria da Ciência [MTC] de Chiappin e a partir da utilização dos instrumentos metodológicos dos programas de pesquisa de Lakatos e. Conforme mencionado, no capítulo anterior, esta metodologia trata de uma proposta de reconstrução de sistemas teóricos como, por exemplo, sistemas científicos e políticos (vistos como um corpo teórico político científico).

O termo reconstrução racional, conforme descrito anteriormente, significa que sistemas teóricos da ciência e da política (vistos como um corpo teórico político científico) constituem um sistema de fins, valores, testes, princípios, métodos, critérios e técnicas que pode ser organizado segundo três níveis conectados, quais sejam: a) Metafísico, b) Lógico e c) Histórico.

Tendo em vista o significado de reconstrução racional, parte-se para efetuá-la na concepção de Bentham. É importante notar que os níveis mais explorados, neste trabalho, serão os níveis metafísicos e lógicos, com ênfase na metodologia, por serem considerados os principais elementos para a compreensão da concepção do autor, bem como para realizar da melhor forma o objetivo deste trabalho, a saber: entender os limites entre ética e legislação utilitarista, do ponto de vista de Bentham. Elementos da metametodologia e da história, apesar de possuírem, aqui, um peso secundário na tentativa de entender os limites entre a ética e a legislação, também serão levados em consideração, especialmente, no capítulo terceiro da dissertação.

O nível Metafísico da concepção de Bentham partilhará de teses axiológicas, epistemológicas e ontológicas. Note-se que a palavra Metafísica, neste caso, implica as principais 
pressuposições feitas pelo sistema de um autor, ou seja, ela não sugere que uma concepção qualquer faz considerações inatistas.

As teses axiológicas, epistemológicas e ontológicas do autor, aqui interpretadas e reconstruídas, bem como o modelo de indivíduo que se pode conceber a partir delas, constituirão a base ou o fundamento de todas afirmações feitas neste trabalho. O nível da lógica, a ser descrito neste capítulo, apresentará, especialmente, os recursos metodológicos do autor, para que as afirmações e problemas levantados, nesta dissertação, possam ser operacionalizados e resolvidos. 


\subsection{O Núcleo da Concepção Utilitarista de Bentham}

A teoria de Jeremy Bentham foi considerada, por hipótese, como a primeira do programa de pesquisa do Utilitarismo ${ }^{6}$. A partir desta eleição, esta teoria será aqui reconstruída, racionalmente, com o auxílio dos instrumentos metodológicos, de Lakatos e Chiappin, descritos na introdução. O núcleo do programa de pesquisa do utilitarismo partilhará de teses ontológicas, axiológicas e epistemológicas, que coincidem com as teses da primeira teoria utilitarista, no caso a de Jeremy Bentham.

O objetivo, expresso por meio de uma tese axiológica, que é possível identificar na obra deste autor, refere-se à construção de um corpo teórico político e moral de caráter científico como forma de fornecer base sólida, calcada em princípios do funcionamento dos indivíduos, que seja capaz de avaliar, de maneira consistente e justa, as ações dentro de uma sociedade.

Seguindo este objetivo (axiologia de fins) de proporcionar fundamentos para avaliar, de forma justa, ações condizentes com o funcionamento do indivíduo, a fim de preservar o bem-estar dentro de uma sociedade, Bentham inicia a argumentação em torno de sua teoria.

Considero como tese epistemológica do autor a afirmação de que o conhecimento é possível a partir da experiência, sem o auxílio de princípios transcendentais a priori. Ou seja, Bentham utiliza a tese epistemológica, denominada tese empirista, de que todo conhecimento provém da experiência:

“[...] Não estamos aqui diante de uma teoria nova e pouco segura, ou inútil. Com efeito, tudo quanto acabamos de expor representa um dado com o qual concorda plena e perfeitamente a experiência do

\footnotetext{
${ }^{6}$ É importante notar que anteriormente a Bentham já se falava em utilidade, como é o caso David Hume. Entretanto, é com Bentham que a formulação do princípio de utilidade vem constituir uma regra de análise das consequêencias das ações em todos os campos da vida moral e política.
} 
gênero humano, onde quer que os homens possuam uma visão clara acerca dos seus próprios interesses [...]".'(Bentham, 1789 p. 24)

Em torno desta tese epistemológica, o autor constrói um recurso metodológico ${ }^{7}$ capaz de operacionalizar sua epistemologia. De acordo com este recurso, o indivíduo seria dotado de duas classes de entidades: a) a perceptiva e b) a inferencial, a partir das quais ele se relaciona com ele mesmo, com os outros e com o mundo. Tais entidades podem ser tanto reais quanto fictícias ${ }^{8}$. Entidades reais são aquelas que possuem existência na realidade das coisas (incluem substâncias corpóreas, coisas materiais e impressões sensoriais como prazer e dor).

As entidades fictícias são nomes cuja existência não lhes pode ser atribuída na realidade. Elas são expressões da linguagem que não podem ser reduzidas gramaticalmente a nomes reais, tais como os substantivos direito, dever, obrigação, lei e ética. Direitos e obrigações são ditos existir, mas nós não descrevemos sua existência na realidade das coisas, como fazemos com entidades reais.

Apesar desta separação entre nomes reais e ficcionais, pode-se dizer que há uma conexão entre ambos os tipos de nomes, pois quando dizemos que temos uma obrigação a ser cumprida ela é verdadeira e real em certa medida. Além disso, todo termo ficcional possui uma relação com um termo real, uma vez que é passível de ocasionar conseqüências que se traduzem em termos de nomes reais, como a geração de prazer ou dor. Assim, uma concepção surge a partir desta relação que passa a exprimir e explicar o termo ficcional.

Então, para evitar obscuridade e mitificação da linguagem Bentham utiliza um modo especial de explicação e análise dos nomes ficcionais. O autor rejeita o método de

\footnotetext{
${ }^{7}$ Este recurso metodológico faz parte da Lógica da Ciência. Sua metodologia será abordada, mais precisamente, na próxima seção.

${ }^{8}$ No que concerne a isto cito Bentham em The Theory of Fictions p. 7: "[...] Entities may be distinguished into perceptible and inferential. An entity, whther perceptible or inferential, is either real or fictitious (...)”.
} 
definição por genus et differentiam, quando se trata de termos ficcionais, pois considera que este modo de exposição (a definição) assume como pressuposto que o termo em questão pertence a uma classe ou agregado de termos, unidos por serem de mesma espécie ${ }^{9}$. Ou seja, para o autor, a definição não constitui um modo adequado de exposição de termos ficcionais, pois estes termos não possuem um genus superior do qual sejam classes ou sub-classes. Assim, não é possível expor, por meio da definição tradicional, termos como direito e dever ${ }^{10}$. Em outras palavras, não é aceitável dizer: "um direito é um..." ou "um dever é um...".

Desta forma, Bentham organizou um novo método de exposição ou análise de termos ficcionais denominado paráfrase. Este método consiste em um tipo de exposição de termos cuja unidade do significado está em frases ou proposições. Neste método uma frase é empregada para expor uma outra frase inteira que contenha a palavra que se quer explicar. Nisto consiste a diferença para o método de exposição de termos a partir da definição, pois nesta apenas uma frase é empregada para explanar uma palavra ${ }^{11}$.

Tal método, denominado paráfrase, consiste, resumidamente, em: a) encontrar uma sentença que contenha o termo ficcional como sujeito, um predicado que designe uma propriedade do sujeito e um termo de ligação entre eles, denominado copula ${ }^{12}$, b) achar uma

\footnotetext{
${ }^{9}$ Sobre isto cito Bentham em Bentham's Theory of Fictions p. 84: “[...] Elliptically but more familiarly, to define a word is to expound it by indication of the genus and the difference-per genus et differentiam, say the Aristotelians. In this account of the matter, two things, it may be observed, are, howsoever inexplicit, assumed: viz. (I) That the object in question belongs to some nest aggregates. (2) That it is not itself the highest, the most capacious: the allcomprehending aggregate of the nest (...)".

${ }^{10}$ A respeito disto cito Bentham em Bentham's Theory of Fictions p. 85: “[...] In the case of all terms of very general import, it will be found much more useful to consider them as genera generalissima and expound them by other means (...)".

${ }^{11}$ No que concerne a isto cito Bentham em Bentham's Theory of Fictions p. 139: “[...] In a definition, a phrase is employed for the exposition of a single word: in a paraphrases, a phrase is employed for the exposition of an entire phrase, of which the word, proposed to be expounded, is made to constitute the principal or characteristic word (...)".

${ }^{12}$ Sobre isto cito Bentham em Bentham's Theory of Fictions p. 86-87: “[...] In every proposition by which a property or affection of any kind, real or fictitious, three parts or members are necessarily either expressly or virtually included, viz. (I) A subject, being the name of the real or fictitious entity in question: (2) A predicate by
} 
tradução para tal sentença em uma ou mais sentenças em que o termo ficcional que se deseja explicar não apareça e que contenha uma concepção de relação com um termo real e c) construir uma imagem a partir de um arquétipo que exprima o termo ficcional, em termos de sensações que se traduzam, especialmente, em prazer e dor ${ }^{13}$.

Ou seja, o objetivo desta forma de explicar termos ficcionais é sempre ter em vista sua relação com termos reais como prazer e dor, pois sem esta relação torna-se impossível estabelecer uma real compreensão destes termos. Em outras palavras, só faz sentido falar de entidades fictícias quando associadas às entidades reais como prazer e dor:

"[...] Of any such fictitious entity, or fictitious entities, the real entity with which the import of their respective appellatives is connected, and on the import of which their import depends, may be termed the real source, efficient cause, or connecting principle [...]". (Bentham, 1814 p.86)

Um exemplo pode ser mostrado através da explicação do termo ficcional obrigação $^{14}$. Inicialmente constrói-se uma proposição com a palavra obrigação como sujeito: “A obrigação é incumbente em um homem". Após a construção desta frase, elabora-se outra em que o termo obrigação não apareça, relacionando-o com um termo real, como no exemplo: a

which is designated the property or affection attributed or ascribed to that subject: and (3) The copula, or sign of the act of the mind by which the attribution or ascription is performed (...)".

${ }^{13}$ Sobre isto cito Bentham em Bentham's Theory of Fictions p. 87: “[...] This image may be termed the archetype, emblem, or archetypal image appertaining to the fictitious proposition of which the name of the characteristic fictitious entity constitutes a part [...]".

${ }^{14}$ No que concerne a isto cito Bentham em Bentham's Theory of Fictions p. 89: “[...] The fictitious entities which compose this group have all of them, for their real source, one and the same sort of real entity, viz sensation: the word being taken in that sense in which it is significative not merely of perception but of perception considered as productive of pain alone of pleasure alone, or of both [...]". 
incumbência traz conseqüências dolorosas a um homem. Por fim constrói-se uma imagem, por meio de um arquétipo que poderia ser a figura de um homem deitado com um peso sobre ele ${ }^{15}$.

A partir desta forma de explicação (paráfrase) que torna possível manter uma relação de termos ficcionais com termos reais (no caso dor) é possível entender o significado de obrigação. Ou seja, a explicação dos termos ficcionais deve, em todos os casos, manter uma relação com os termos reais, para que as conseqüências dos primeiros termos possam ser traduzidas pelas conseqüências dos segundos.

Assim, tendo em vista a tese epistemológica de Bentham, a partir da qual o conhecimento provém da experiência e seu recurso metodológico para operacionalizá-la (que divide as entidades entre reais e ficcionais), conclui-se que termos como legislação, ética, obrigação, dever, direito e outros não são entes misteriosos ou naturais, mas sim construções humanas que podem e devem ser alteradas sempre com vistas a suscitar mais prazer do que dor para indivíduos.

Da epistemologia do autor depreende-se ${ }^{16}$ a tese ontológica que identifica prazer, dor e o indivíduo com entidades reais, ou seja, para análise política o que existe é o indivíduo capaz de experimentar duas sensações também reais, a saber: prazer e dor. Assim, os princípios da moral e da legislação de Bentham são construídos a partir de considerações a respeito do indivíduo $^{17}$. Segue-se desta proposição ontológica uma série de conseqüências metodológicas,

\footnotetext{
${ }^{15}$ No que concerne a isto cito Bentham em Bentham's Theory of Fictions p. 90: "[...] the emblematical, or archetypal image, is that of a man lying down, with a heavy body pressing upon him [...]".

${ }^{16} \mathrm{Faz}-\mathrm{se}$, aqui, a pressuposição de que a epistemologia determina ou implica elementos ontológicos.

${ }^{17}$ Sobre isto cito Jeremy Bentham em Uma Introdução aos Princípios da Moral e da Legislação p. 10: "[...] É inútil falar do interesse da comunidade, se não se compreender qual é o interesse do indivíduo. Diz-se que uma coisa promove o interesse de um individuo, quando tende a aumentar a soma total de seus prazeres, ou então, o que vale afirmar o mesmo, quando tende a diminuir a soma total das suas dores [...]".
} 
entre elas, a de que a sociedade ou comunidade, para Bentham, nada mais é do que a soma dos indivíduos que a integram, ou em suas palavras, um corpo fictício ${ }^{18}$.

O modelo de indivíduo que é expresso a partir da epistemologia e da ontologia do autor é o seguinte: a) o indivíduo dotado da capacidade de experimentar duas sensações reais (prazer e dor) é a entidade ontológica fundamental, para análise política, pois é o único que possui existência na realidade, b) este indivíduo busca o prazer e foge da dor, ou seja, é autointeressado ${ }^{19}$ e c) o indivíduo possui a faculdade intelectual de uma razão que calcula, ele é capaz de fazer cálculos intertemporais, inclusive no que diz respeito às conseqüências das ações. Para a realização de um ato, segundo Bentham, o indivíduo conta, ainda, com o estado da vontade $(\text { intenção })^{20}$.

A primeira afirmação, deste trabalho, sobre o modelo de indivíduo, referente à tese de que ele é a entidade ontológica fundamental para análise política, remete ao recurso epistemológico criado pelo autor, acima descrito. Ou seja, a divisão dos termos entre reais e ficcionais, resultantes deste recurso metodológico de sua epistemologia, induz à conclusão de que para fins de análise política, o único elemento que possui existência ontológica é: o indivíduo ${ }^{21}$ dotado de duas entidades, também reais, prazer e dor. Os outros termos políticos como comunidade, sociedade, direito, dever, obrigação, lei, constituem termos ficcionais, sem

\footnotetext{
${ }^{18}$ Sobre isto cito Jeremy Bentham em An Introduction to the Principles of Morals and Legislation p. 10: "[...] The community is a fictitious body, composed of the individual persons who are considered as constituting as it were its members. The interest of the community then is, what? -the sum of the interests of the several members who compose it [...]".

${ }^{19}$ Sobre isto cito Jeremy Bentham em A Table of Springs of Actions p. 211-212: “[...] In regard to interest, in the most extended, - which is the original and only strictly proper sense, -of the word disinterested, no human act ever has been, or ever can be, disinterested. For there exists not ever any voluntary action which is not the result of the operation of some motive, which has not for its accompaniment a corresponding interest, real or imagined [...]". ${ }^{20} \mathrm{~A}$ vontade seria uma faculdade ativa do intelecto.

${ }^{21}$ A respeito disto cito Bentham em An Introduction to the Principles of Morals and Legislation p. 2: "[...] It is in vain to talk of the interest of the interest of the community, without understanding what is the interest of the individual [...]".
} 
existência na realidade das coisas. Alguma existência lhes pode ser atribuída, apenas quando relacionados a termos reais, conforme descrito acima.

A segunda afirmação, deste trabalho, referente ao fato do indivíduo ser autointeressado, é efetuada, pois é possível verificar um maior número de passagens que sugerem que o indivíduo realiza todos seus esforços, sempre, no sentido de maximizar seu prazer e fugir da dor. Em outras palavras este indivíduo age, em todos os casos, com o intuito de realizar seus próprios interesses. Restará claro no capítulo terceiro e quarto, desta dissertação, que o fato do indivíduo ser auto-interessado não implica uma visão egoísta ou excludente de preocupação com os interesses dos outros membros da comunidade. Ao contrário, tentar-se-á mostrar que este indivíduo, quando compreende, que o somatório de prazer, da comunidade, deve ser maximizado, sempre, terá bons motivos para fazer convergir seus interesses com os de outros indivíduos.

A terceira afirmação sobre o modelo de indivíduo que diz respeito à sua racionalidade é chamada, metodologicamente, pelo autor, de faculdade intelectual. A principal característica desta faculdade intelectual refere-se à capacidade que ela possui de efetuar cálculos, previsões e antecipações das conseqüências das ações, com base em experiências passadas e levando em conta a imaginação. Esta razão que calcula prevê, compara e estima os valores de prazeres e dores que acompanham as ações ${ }^{22}$. Os homens são, assim, diferenciados dos animais, especialmente, por possuírem uma razão capaz de efetuar cálculos intertemporais

\footnotetext{
${ }^{22}$ A respeito disto cito Jeremy Bentham em Déontologie ou Science de la Morale p.144: “[...] La raison fait servir les événements de l'un à l'instruction de l'autre : elle appelle à son aide non seulement l'expérience, mais encore l'imagination. Le domaine de son influence est sans limite comme la pensée : elle recherche les conséquences, et les présente aux regards de l'investigateur : elle dégage les peines et les plaisirs de l'alliage qui les accompagne : elle analyse leur valeur en les divisant dans leurs parties constitutives, ou les réunit en un tout afin de s'assurer de leur somme totale : elle les compare l'un avec l'autre quand ils sont classés chacun dans sa division respective, et de ces éléments réunis elle généralise et déduit le résultat définitif [...]".
} 
que antecipa e faz previsões sobre as conseqüências de ações ${ }^{23}$. O exercício da razão humana constitui o principal instrumento de condução dos homens à felicidade.

Por meio destas considerações sobre o modelo de indivíduo de Bentham, é possível depreender que as ações humanas são guiadas pelos sentimentos de prazer e dor. São eles que apontam o que se deve fazer, bem como o que de fato os indivíduos fazem. Bentham ressalta que estes são os dois senhores soberanos das nossas ações e pensamentos. Aos prazeres e dores estão vinculadas: a) a norma que distingue o que é certo do que é errado e b) a cadeia de causas e efeitos de uma ação ${ }^{24}$.

Tendo em vista os sentimentos de prazer e dor como aquilo que governa ${ }^{25}$ as ações humanas, o autor descreve o princípio da utilidade como aquele que reconhece a sujeição do indivíduo a estes sentimentos e tem o objetivo de colocá-los como fundamento para a construção de um corpo teórico que vise a melhor sociedade possível ${ }^{26}$.

Dentro deste contexto a explicação do princípio é formulada, por Bentham, da seguinte maneira:

“[...] Por princípio da utilidade entende-se aquele princípio que aprova ou desaprova qualquer ação, segundo a tendência que

\footnotetext{
${ }^{23}$ A respeito disto cito Jeremy Bentham em Déontologie ou Science de la Morale p.144: “[...] La plupart des animaux inférieurs ne sont arrêtés dans leur recherche du plaisir par aucune anticipation de peine à venir. Nulle appréhension des conséquences ne peut les engager à s'abstenir d'une jouissance actuelle. Si l'on en excepte quelques uns des plus intelligents, toutes les leçons sont perdues pour eux, même celles de l'expérience : peut-être aussi cette perte de l'expérience est-elle attribuable à l'imperfection de leur mémoire [...]".

${ }^{24}$ Sobre isto cito Jeremy Bentham em Uma Introdução aos Princípios da Moral e da Legislação p. 10: "[...] $A$ natureza colocou o gênero humano sob o domínio de dois senhores soberanos: a dor e o prazer. Somente a eles compete apontar o que na realidade faremos. Ao trono desses dois senhores está vinculada a norma que distingue o que é reto do que é errado, e por outra, a cadeia das causas e dos efeitos [...]".

${ }^{25}$ Sobre isto cito Jeremy Bentham em Uma Introdução aos Princípios da Moral e da Legislação p. 9: “[...] Os dois senhores de que falamos nos governam em tudo o que fazemos, em tudo o que dizemos, em tudo o que pensamos, sendo que qualquer tentativa que façamos para sacudir este senhorio outra coisa não faz senão demonstra-lo e confirmá-lo [...]".

${ }^{26}$ Sobre isto cito Jeremy Bentham em Uma Introdução aos Princípios da Moral e da Legislação p. 9: "[...] $O$ princípio da utilidade reconhece esta sujeição e a coloca como fundamento desse sistema, cujo objetivo consiste em construir o edifício da felicidade através da razão e da lei [...]".
} 
tem a aumentar ou a diminuir a felicidade da pessoa $^{27}$ cujo interesse está em jogo, ou, o que é a mesma coisa em outros termos, segundo a tendência a promover ou a comprometer a referida felicidade. Digo qualquer ação, com o que tenciono dizer que isto vale não somente para qualquer ação de um indivíduo particular, mas também de qualquer ato ou medida de governo [...]”. Ou, em outros termos, o princípio da utilidade é explicado da seguinte forma: "[...] O princípio que estabelece a maior felicidade de todos aqueles cujo interesse está em jogo, como sendo a justa e adequada finalidade da ação humana, e até a única finalidade justa, adequada e universalmente desejável: da ação humana, digo, em qualquer situação ou estado de vida, sobretudo na condição de um funcionário ou grupo de funcionários que exercem os poderes do governo [...]".(Bentham, 1789, p.10).

Reconhecida, pelo princípio da utilidade, a sujeição do gênero humano aos sentimentos de prazer (felicidade) e dor (infelicidade), este passa a ser a norma para julgamento do que é certo e errado, bem como a norma que distingue a cadeia de causas e efeitos de uma ação. Ou seja, o princípio de utilidade é aquele que reconhece a justeza de uma ação de acordo com suas conseqüências. Ele representa uma regra metodológica que aponta que aquilo que deve ser levado em conta (avaliado), em todas as circunstâncias, são as conseqüências das ações. Em outras palavras, este princípio considera uma ação justa pela capacidade que tem de gerar mais prazer do que dor e injusta por ocasionar mais dor do que prazer.

A partir deste núcleo ontológico (que descreve o modelo do indivíduo e coloca o princípio da utilidade como aquele que está de acordo com este modelo), do núcleo axiológico

\footnotetext{
${ }^{27}$ É importante notar que a primeira definição de princípio de utilidade talvez possua uma tradução equivocada do
} termo party, pois é traduzido como pessoa, quando em inglês este termo pode ter um significado coletivo. 
(que coloca como objetivo a construção de uma legislação e de uma moral justa, para construir o edificio da felicidade de uma sociedade) e do núcleo epistemológico (que diz que todo conhecimento provém da experiência ${ }^{28}$ ), Bentham passa a erigir uma heurística positiva composta de conceitos metodológicos capazes de operacionalizar e explicar a aplicação do princípio da utilidade para avaliar as ações humanas.

As teses que compõem o núcleo da concepção de Bentham, aqui identificadas e interpretadas, aliadas à sua heurística positiva (composto de seu nível lógico) constituem os elementos centrais que irão acompanhar o decorrer de todo este trabalho, na tentativa de entender quais são os limites entre a ética e a legislação, para este autor.

\footnotetext{
${ }^{28}$ A sujeição do indivíduo aos sentimentos de prazer e dor, para Bentham, não constitui uma tese metafísica, mas apenas a observação da experiência. Sobre isto cito Jeremy Bentham em Uma Introdução aos Princípios da Moral e da Legislação p. 11: "[...] Em virtude da própria constituição natural da estrutura humana, na maioria das ocasiões da sua vida os homens geralmente abraçam este princípio sem pensar explicitamente nele: se não para orientar a sua própria conduta, pelo menos para julgar as suas próprias ações, bem como as dos outros [...] ".
} 


\subsection{A Lógica da Concepção de Bentham: Sua Metodologia.}

Como mencionado anteriormente, o patamar da Lógica da Metodologia da Teoria da ciência [MTC] como recurso para a reconstrução racional de uma concepção é constituído por uma metodologia e uma metametodologia. Este nível pode vir a formar parte da heurística positiva de um programa de pesquisa sobre o utilitarismo no desenvolvimento, futuro, deste trabalho. A construção e identificação dos recursos, instrumentos metodológicos e critérios de análise de Bentham são fundamentais para operacionalização de suas principais teses, identificadas no núcleo ou âmbito metafísico de sua concepção. Conforme visto, o principal objetivo de Bentham é o de construir uma ciência da ação humana, dando à moral e à legislação um caráter científico. Isto requer uma metodologia para avaliar as proposições sobre as ações humanas. O núcleo dessa metodologia refere-se ao princípio da utilidade que pode ser interpretado como uma regra que indica que as ações são avaliadas ou julgadas não pela intenção dos agentes (subjetividade), mas sim pelas conseqüências dos atos. A abordagem do julgamento das conseqüências é feita pelo teste empírico dado pela produção de prazer ou dor. Em outros termos, tudo que o autor quer é afirmar que o melhor modo de compreender as ações se dá por meio de suas conseqüências. Estas conseqüências estão associadas à produção de elementos empíricos como prazeres e dores. Tendo em vista este fator, pode-se dizer que a criação de seus métodos de análise das conseqüências visa a permitir a operacionalização e a facilidade da compreensão dos elementos que geram prazer e dor. 
Poder-se-ia questionar porque há este interesse do autor em construir uma metodologia capaz de viabilizar o melhor entendimento da produção de prazer ou dor e, portanto, da geração de conseqüências das ações. A resposta concorda com o núcleo de sua teoria descrito na seção anterior, pois tendo em vista o modelo de indivíduo que reconhece que o agente está sujeito aos sentimentos de prazer e dor e a axiologia de fins que procura uma forma justa de avaliar as conseqüências das ações, dentro de uma comunidade, é fundamental que todos os elementos que possam interferir, de alguma forma, na produção dessas conseqüências sejam levados em consideração.

O princípio de utilidade é ele mesmo uma regra que enuncia que aquilo que importa são as conseqüências das ações. Em outras palavras, exatamente porque o princípio de utilidade reconhece que o gênero humano está sob a sujeição dos sentimentos de prazer e dor é que ele prescreve que a forma justa de avaliar ações dá-se pela pelo exame da produção destes sentimentos, através das conseqüências das ações.

Tendo em vista a importância das conseqüências das ações para efetuar qualquer julgamento, é possível afirmar que os outros elementos, inclusive metodológicos, que o autor elabora, apresentarão maior ou menor grau de relevância, dependendo da forma como relacionam-se com a produção de prazer ou dor. Ou seja, todos os instrumentos metodológicos criados por Bentham possuem como objetivo aclarar ou tornar mais precisa a análise das conseqüências das ações. Muitas vezes, estes recursos são meramente retóricos, pois possuem a finalidade de estabelecer diálogo com o senso comum.

Considerando-se estas afirmações iniciais procede-se à reconstrução dos elementos metodológicos do autor. Dentro da heurística positiva ou metodologia de sua teoria, os primeiros pontos levantados por Bentham referem-se às causas eficientes, ou meios, capazes de provocar prazer ou dor em um indivíduo. As causas para a obtenção do prazer ou dor são instrumentos 
metodológicos, dentro da heurística positiva, que possibilitam descrever os tipos de aprovação ou reprovação que um indivíduo pode enfrentar.

Segundo o autor, existem quatro fontes distintas que ocasionam prazer e dor: a) física, b) política, c) moral e d) religiosa ${ }^{29}$. Se o prazer ou a dor se espera na vida presente e no curso ordinário da natureza, então, o prazer é denominado sanção física. Se for esperado de uma pessoa ou de um grupo da comunidade, sob nome de juiz, pode-se dizer que é derivado da sanção política. Caso o poder de gerar prazer ou dor estiver nas mãos de pessoas que por acaso ocupam um lugar de destaque na comunidade, segundo disposição espontânea, pode-se dizer que o prazer e a dor derivam da sanção moral. Se dependerem de ser superior invisível, quer na vida presente, ou na vida futura, então é derivado de sanção religiosa ${ }^{30}$.

O autor ressalta que apenas nos ocupamos dos prazeres da vida presente, além disso, acrescenta que os prazeres pertencentes a cada sanção são iguais, uma vez que são sentidos fisicamente ${ }^{31}$. A única diferença encontra-se nas circunstâncias que acompanham a sua produção (por exemplo: a circunstância ou fonte política é diferente da circunstância ou fonte moral) ${ }^{32}$.

Disto, é possível depreender que a sanção física é o fundamento da sanção política, moral e religiosa. Nenhuma destas fontes pode operar senão por meio das forças da natureza, por

\footnotetext{
${ }^{29}$ Sobre isto cito Jeremy Bentham em Uma Introdução aos Princípios da Moral e da Legislação p. 19: “[...] Existem quatro fontes distintas, das quais costumam derivar o prazer e a dor: consideradas em separado, podemos designalas como fontes física, fonte política, fonte moral e fonte religiosa. Na medida em que os prazeres e as dores pertencentes a cada uma delas são capazes de emprestar a qualquer lei ou regra de conduta uma força obrigatória, todas elas podem ser denominadas sanções [...]”.

${ }^{30}$ Bentham acrescenta a sanção religiosa como forma de dialogar com o público de sua época.

${ }^{31}$ Bentham chama os prazeres de "pathological". Aqueles que não são desta espécie, como os prazeres da mente, são denominados inertes. Sobre isto cito Bentham em a Table of Springs of Actions p. 206:"'[...] For pathological might here have been put the more ordinary adjunct physical, were it not that, in the case, those pleasures and pains, the seat of which is not in the body but only in the mind, might be regarded as excluded [...]".

${ }^{32}$ Com respeito a isto cito Jeremy Bentham em Uma Introdução aos Princípios da Moral e da Legislação p. 20: “[...] No que respeita, portanto, aos prazeres e às dores da vida presente [...] podemos afirmar o seguinte: aqueles que pertencem a qualquer uma dessas sanções, em última análise, não diferem especificamente daqueles que pertencem a qualquer uma das outras três: a única diferença existente entre eles reside nas circunstâncias que acompanham a sua produção [...]”.".
} 
meio do prazer ou dor física ${ }^{33}$. Por este motivo, torna-se possível comparar, metodologicamente, os prazeres e dores de cada pessoa, diferenciado-os por sua quantidade (mais prazer, mais dor, menos prazer, menos dor).

A partir das fontes geradoras de prazer e dor (física, política, moral e religiosa) um recurso metodológico é criado para nomear os tipos de sofrimento por meio dos quais uma pessoa pode ser vítima, a saber: a) calamidade: é um sofrimento que atinge uma pessoa no decurso natural dos acontecimentos, b) punição: é o tipo de sofrimento imposto por uma lei, c) recusa de ajuda amigável representa um sofrimento imposto por uma sanção moral (ocorre devido a uma suposta má conduta) e d) providência particular refere-se a um sofrimento que ocorre por interposição direta de uma providência particular, derivado de uma sanção religiosa.

Após a identificação metodológica dos tipos de sofrimento feitos através da descrição das fontes de prazer ou dor, o autor tenta tornar estes sentimentos mais operacionais com vistas a facilitar o trabalho do legislador que segue o princípio da utilidade. Ou seja, o autor elabora mais um recurso metodológico para fornecer auxílio na tentativa de conhecer os valores ${ }^{34}$ dos prazeres e dores.

É importante, para análise de Bentham, que os valores do prazer e dor de cada indivíduo possam ser medidos, pois será a quantidade de prazer ou dor que fornecerá respostas sobre a tendência boa ou má dos atos. Esta análise de conseqüências das ações constituirá o guia responsável pelas decisões dos governantes no que diz respeito às recompensas (no caso de ação geradora de mais prazer do que dor) e às punições (no caso de predominância de dor).

\footnotetext{
${ }^{33}$ A respeito disto cito Jeremy Bentham em Uma Introdução aos Princípios da Moral e da Legislação p. 21: “[...] das quatro sanções de que tratamos até aqui, podemos observar que a física é o fundamento da política e da moral, o mesmo acontecendo em relação a religiosa, na medida em que se relaciona com a vida presente [...]".

${ }^{34}$ Sobre isto cito Jeremy Bentham em Uma Introdução aos Princípios da Moral e da Legislação p. 22: "[...] Os prazeres e as dores constituem os instrumentos com os quais o legislador deve trabalhar. Por este motivo convém que compreenda a força dos mesmos, ou seja, em outros termos, o seu valor [...]".
} 
O recurso metodológico utilizado para mensuração do prazer e dor inicia-se com considerações sobre os indivíduos afetados pela ação em questão. Não poderia ocorrer de outra maneira, dado que é sustentada, neste trabalho, a tese ontológica que identifica o indivíduo como aquele que possui existência para análise política. Tendo em vista este fator, procede-se à tentativa de Bentham de mensurar os valores de prazeres e dores.

Para um indivíduo considerado em si mesmo, o valor de um prazer ou de uma dor será maior ou menor segundo as quatro circunstâncias ou propriedades: 1) intensidade, 2) duração, 3) certeza ou incerteza, 4) proximidade ou longinquidade ${ }^{35}$. Com relação à tendência geral do ato (conseqüências das ações), leva-se em conta duas outras circunstâncias ou propriedades, quais sejam: 5) fecundidade (probabilidade que o prazer ou a dor tem de serem seguidos por sensações de mesma espécie) e 6) pureza (probabilidade que o prazer e a dor possuem de não serem seguidos por sensações contrárias) ${ }^{36}$.

A seguir verifica-se a extensão ou o número de indivíduos afetados pela ação avaliada. Considerando estes elementos, o valor do prazer e da dor será maior ou menor conforme as sete circunstâncias: 1) intensidade, 2) duração, 3) certeza ou incerteza, 4) proximidade ou longinquidade, 5) fecundidade, 6) pureza, e 7) extensão (número de pessoas as quais se estende o respectivo prazer ou dor ${ }^{37}$ ).

Assim, para realizar-se a avaliação exata da tendência geral de qualquer ato que afeta os interesses de uma coletividade, procede-se começando por qualquer pessoa cujos interesses pareçam ser mais imediatamente afetados pelo ato e apreciam-se os seguintes elementos: 1) o valor de cada prazer distinto que se manifesta como produzido pelo ato em

\footnotetext{
${ }^{35}$ Estes recursos utilizados para avaliar as propriedades do prazer ou dor, descritos pelo autor, reiteram o modelo de indivíduo que diz que o agente é capaz de efetuar cálculos intertemporais sobre prazeres e dores.

${ }^{36}$ Ambas as circunstâncias não são propriedades do prazer ou da dor. Portanto, só devem ser consideradas na avaliação da tendência do ato.

${ }^{37}$ Note-se que a soma dos prazeres e dores de indivíduos só é possível porque os prazeres sentidos por cada um são iguais, diferindo apenas com relação às seis circunstâncias mencionadas .
} 
primeira instância (variará segundo a intensidade, duração, proximidade ou longinquidade, certeza ou incerteza), 2) faz-se o mesmo para a dor, 3) o valor de cada prazer produzido pelo ato após o primeiro prazer, que é a fecundidade do primeiro prazer (e a impureza da primeira dor), 4) procede-se o mesmo para a dor, 5) somam-se todos os valores dos prazeres de um lado e os valores de todas as dores do outro. O balanço, se for favorável ao prazer, indicará a tendência boa do ato, para o primeiro indivíduo. Se for favorável à dor, indicará a tendência má do ato, para este mesmo agente, 6) faz-se uma avaliação do número de pessoas cujos interesses aparecem em jogo e repete-se o procedimento acima em relação a cada um dos indivíduos, 7) a seguir, aplicase, então, o princípio de agregação das conseqüências da ação: soma-se ${ }^{38}$ o número de graus de tendência boa com relação a cada um dos indivíduos, 8) faz-se o mesmo com respeito a cada indivíduo cuja tendência do ato é má, em seu conjunto e 9) feito isto, procede-se ao balanço. Este se for favorável ao prazer assinalará a tendência boa geral do ato. Se o balanço pesar para a dor, teremos a tendência má geral do ato ${ }^{39}$.

Quando o ato possui tendência geral má (conseqüências nefastas) cabe aos governantes manter a felicidade da comunidade através da punição ${ }^{40}$. Segundo autor, a obrigatoriedade ou necessidade de punir uma ação é proporcional aos seguintes fatores: a) na medida em que tende a perturbar a felicidade da comunidade e b) na medida em que o ato é pernicioso. Disto depreende-se que a punição será estipulada, tendo em vista as conseqüências

\footnotetext{
${ }^{38}$ Note que é possível somar as tendências boas e más dos atos, porque qualitativamente e quantitativamente os prazeres, sentidos por cada indivíduo, são comparáveis são ditos "pathological" ou em outros termos físicos.

${ }^{39}$ Apesar de insistir na adoção deste método, o autor diz que "[...] Não se pode esperar que o referido método possa ser seguido a rigor antes de qualquer julgamento moral, ou antes de qualquer ação legislativa ou judicial. Todavia o método como tal pode ser sempre mantido diante dos olhos: e, na medida em que o processo atualmente seguido nessas ocasiões se aproximar dele, na mesma medida tal processo se aproximará da exatidão [...]”. Citação de uma Introdução aos Princípios da Moral e da Legislação p. 24.

${ }^{40}$ Sobre isto cito Jeremy Bentham em Uma Introdução aos Princípios da Moral e da Legislação p. 25: "[...] parte da missão do governo que consiste em punir constitui mais particularmente o objeto da lei penal. A obrigatoriedade ou necessidade de punir uma ação é proporcional à medida em que tal ação tende a perturbar a felicidade e á medida em que a tendência do referido ato é perniciosa. Ora a felicidade consiste naquilo que já vimos, em desfrutar prazeres e estar isento de dores [...]".
} 
causadas pelas ações ou em outros termos, pela capacidade que uma ação possui de ocasionar dores. Em outros termos, Bentham estabelece uma regra que privilegia a proporcionalidade entre crime e punição, sempre com o objetivo de impedir crimes futuros.

Entretanto, para aprimorar a compreensão da gravidade dos efeitos produzidos por um ato (sempre se reduzem a prazeres e dores), o autor cria recursos metodológicos ${ }^{41}$ adicionais ao seu método de mensuração dos valores de prazeres e dores, a fim de avaliar mais precisamente às conseqüências das ações. Estes recursos metodológicos são elementos que se agregam às ações, a saber: a) o ato em si, b) as circunstâncias que acompanham o ato, c) a intenção, d) a consciência, e) os motivos que produzem uma intenção (ou vontade) de realizar um ato e f) a disposição.

Os primeiros instrumentos metodológicos que se agregam às ações, na análise de suas conseqüências, são os próprios atos. Estes podem ser materiais quando ocasionam a produção de prazeres ou dores ou imateriais quando não se relacionam à geração de prazeres ou dores. Um ato, segundo o autor, é um ato do corpo ou da mente (relaciona-se à faculdade intelectiva ou à vontade). Atos da mente podem ser puramente intelectivos que exercem influência na vontade ou atos apenas da vontade.

Para o autor, atos puros da faculdade intelectiva são apenas especulativos. Tais atos não são passíveis de ocasionar a geração de dor ou prazer. Portanto, o ato que é resultado somente da faculdade intelectiva é denominado imaterial. Os atos do corpo, atos da vontade e atos intelectivos que exercem influência na vontade são considerados materiais por desempenharem influência sobre indivíduos no que concerne à geração de dor ou prazer.

\footnotetext{
${ }^{41}$ A respeito disto cito Jeremy Bentham em Uma Introdução aos Princípios da Moral e da Legislação p. 27: “[...] Em cada ação, portanto, que examinarmos com vistas à punição, há quatro elementos a serem levados em consideração: (1) o próprio ato que é praticado: (2) as circunstâncias nas quais o ato é praticado: (3) a intenção que pode ter acompanhado o ato: (4) a consciência, inconsciência ou falsa consciência, que pode ter acompanhado $o$ ato [...] Existem ainda dois outros fatores dos quais depende a tendencia geral de um ato e, por via de conseqüência, a exigência de puni-lo. Tais fatores são: (1) o motivo [...] e (2) a disposição [...]”."
} 
Assim, os atos quando são consideradas materiais (capazes de produzir prazer ou dor) podem ser de três tipos, quais sejam: a) de um indivíduo para consigo mesmo (podendo causar prazer ou dor), b) de um indivíduo para com outros de forma positiva (buscando gerar prazer e c) de um indivíduo para com outros de forma negativa, abstendo-se ou não de gerar $\operatorname{dor}^{42}$.

Disto depreende-se que a materialidade dos atos liga-se às conseqüências das ações através da possibilidade de produção de prazer ou dor. Em outros termos, os atos apenas serão considerados materiais caso gerem conseqüências que se traduzam em termos de prazer ou dor.

Entendido o papel dos atos na produção de conseqüências e, portanto, no maior esclarecimento de como estes são capazes de gerar prazer ou dor, o autor analisa a conexão entre as circunstâncias que circundam um ato e as conseqüências dele.

As circunstâncias do ato, também, constituem um recurso metodológico que deve ser levado em conta, pois a partir de sua consideração refina-se a certeza de quais serão as conseqüências de uma dada ação ${ }^{43}$. Segundo o autor, é fundamental que as circunstâncias sejam analisadas, uma vez que seu exame pode modificar, completamente, a interpretação das conseqüências de uma ação. Em certas ocasiões até o ato de matar uma pessoa pode ser benéfico ${ }^{44}$.

\footnotetext{
${ }^{42}$ Sobre isto cito Jeremy Bentham em Uma Introdução aos Princípios da Moral e da Legislação p. 70 "[...] Na medida em que a felicidade depende do primeiro setor mencionado, diz-se que a sua felicidade depende da sua obrigação em relação a si mesmo [...]". "[...] Ora, a felicidade de alguém pode ser salvaguardada ou aumentada de duas maneiras [...]": (1) de uma forma negativa, abstendo-se de diminui-la: (2) de uma forma positiva, procurando aumentá-la [...]".

${ }^{43}$ A respeito disto cito Jeremy Bentham em Uma Introdução aos Princípios da Moral e da Legislação p. 26: “[...] Abordaremos agora as circunstâncias que podem ter acompanhado os atos. Estas devem necessariamente ser levadas em consideração, e isto antes de podermos determinar qualquer coisa acerca das conseqüências. Com feito, de outra forma nunca poderemos ter certeza sobre quais possam ser as conseqüencias de um ato em seu conjunto. Em outros termos: de outra forma nunca poderemos saber se o ato é benéfico, ou indiferente, ou prejudicial [...]".

${ }^{44}$ Sobre isto cito Jeremy Bentham em Uma Introdução aos Princípios da Moral e da Legislação p. 26: “[... Em Em certas circunstâncias até o matar uma pessoa pode constituir um ato benéfico, ao passo que em outras pode constituir fato pernicioso o simples oferecer um alimento a uma pessoa [...]".
} 
Contudo, indaga-se: no que consistem as circunstâncias de um ato? A resposta é simples: podem ser qualquer evento conectado à ação em questão. Assim como os atos, as circunstâncias dele também podem ser materiais ou imateriais. Novamente, a materialidade está relacionada à dor e prazer, em se tratando das conseqüências. No caso das circunstâncias, a sua materialidade, encontra-se nas relações que possuem com as conseqüências, em outros termos, uma circunstância é material quando, do ponto de vista da causalidade, apresenta uma relação visível com as conseqüências.

Com este recurso metodológico denominado circunstância o autor efetua uma subdivisão entre tipos de circunstâncias para que se possa entender como é possível relacioná-las às conseqüências dos atos. Ele enumera quatro formas pelas quais as circunstâncias conectam-se às conseqüências, a saber: a) por via de causalidade produtora (neste caso a circunstância produz conseqüência), b) por via de derivação (neste caso a circunstância contribui para produzir a conseqüência), c) por via de conexão colateral, ocorre quando as circunstâncias e conseqüências se relacionam a alguma coisa comum (implicada na produção das circunstâncias e conseqüências) e d) por via de influência conjunta (as circunstâncias e as conseqüências contribuem para a produção de outra conseqüência).

É necessário efetuar a subdivisão metodológica do recurso denominado circunstância, pois as várias relações descritas acima não dizem respeito todas ao mesmo evento (conseqüência) com a mesma certeza. As circunstâncias mais raras são as que ocorrem por via de derivação e de influência conjunta. A materialidade das circunstâncias será determinada por duas considerações: a) pela natureza dos próprios casos (casos mais simples ou mais complexos) e b) pela força ou fraqueza das faculdades daqueles que investigam o caso.

Assim, o exame da materialidade das circunstâncias constitui um recurso metodológico adicional ao método de soma de prazer e dor e também suplementar à análise da 
materialidade dos atos, uma vez que a partir de sua observação torna-se possível entender, de maneira mais refinada, as conseqüências das ações.

Explicada as relações que as circunstâncias podem ter com as conseqüências de um ato e, portanto, com a produção de prazeres e dores, descreve-se as relações que o recurso metodológico denominado intenção ou vontade pode possuir com as conseqüências. Segundo Bentham, a intenção ou vontade refere-se a dois fatores: ou às conseqüências do ato propriamente ditas ou ao ato em si. Dos dois fatores os que forem afetados pela intenção serão chamados intencionais.

Um ato pode ser intencional sem que seja a conseqüência. Contudo, o ato não poderá ser não intencional em sua totalidade. Ele terá que ser intencional, ao menos em parte, pois se a primeira parte do ato (a intenção de realizar o movimento do ato) não for da vontade do indivíduo, então este ato será considerado de outra pessoa.

Portanto, um ato pode ser não intencional em quaisquer fases, contanto que a primeira etapa seja intencional. Ressalta-se que é irrelevante saber se o ato foi intencional em qualquer etapa precedente, pois se não for propositado na última fase o ato pode ser dito não intencional. Ou seja, mais uma vez destaca-se a importância de efetuar a conexão destes instrumentos metodológicos com as conseqüências das ações.

Só é possível, para aquele que julga um ato, avaliar se uma intenção foi boa ou má ${ }^{45}$ através de pontos materiais ou provas. Estas provas são indícios de que o agente possuía bom conhecimento das circunstâncias quando praticou o ato, ou seja, o fato do indivíduo estar ciente de quais eram os problemas ou dificuldades que envolveriam seu ato é um indício de que ele

\footnotetext{
${ }^{45}$ É importante lembrar que só o prazer ou a dor são bons ou maus em si mesmos, a bondade ou maldade da intenção está relacionada com o fato de gerar prazer ou dor. Sobre isto cito Jeremy Bentham em Uma Introdução aos Princípios da Moral e da Legislação p. 30: "[...] Falando-se a rigor, nada pode dizer-se bom ou mau, a não ser exclusivamente se for considerado em si mesmo - o que acontece somente com a dor ou prazer-ou então, em razão de seus efeitos -o que acontece exclusivamente no caso de coisas que produzem ou afastam o prazer e a dor [...]".
} 
pretendia provocar (intencionalmente) as conseqüências ocorridas. Com isto, poder-se-ia dizer que sua intenção foi perversa, na realização do ato, no caso das conseqüências produzirem mais dor do que prazer ${ }^{46}$.

Desta forma, pelo fato de não podermos ter certeza, ou uma forma clara e distinta de julgar a intenção de um indivíduo, reduz-se sua análise, apenas e tão somente, àqueles casos em que se possui prova material de que um indivíduo pretendia, intencionalmente, produzir as conseqüências de um ato qualquer.

Entendida a relação entre o instrumento metodológico intenção na produção de um ato e as implicações possíveis em termos de prazer e dor, busca-se analisar a relação do recurso metodológico denominado consciência ou faculdade intelectiva com a produção das conseqüências de uma ação.

A importância da consciência ou faculdade intelectiva na produção de conseqüências está relacionada ao conhecimento ou ignorância em relação às circunstâncias que acompanham um ato ${ }^{47}$.

Com respeito ao conhecimento das circunstâncias, a faculdade de percepção (ou inteligência) possui três estados: a) consciência, quando o indivíduo acredita haver as circunstâncias que realmente existem, b) inconsciência, nesta situação a pessoa deixa de perceber a existência de certas circunstâncias e c) falsa consciência é o estado em que a pessoa acredita haver circunstâncias que não existem.

\footnotetext{
${ }^{46}$ A respeito disto cito Jeremy Bentham em Uma Introdução aos Princípios da Moral e da Legislação p. 31: “[...] Se a intenção for qualificada boa ou má em algum sentido, será necessariamente ou porque se acredita que ela produz boas ou más conseqüências [...]".

${ }^{47}$ Sobre isto cito Jeremy Bentham em Uma Introdução aos Princípios da Moral e da Legislação p. 31: "[...] as circunstâncias como tais são apenas objetos da inteligência. Em relação a elas a única coisa que podemos fazer é conhecê-las ou não conhecê-las: em outras palavras, ter consciência delas ou não tê-la. Ao item consciência pertence o que se pode e deve dizer acerca da qualidade boa ou má da intenção de uma pessoa [...]”."
} 
Da compreensão destes três estados em que se pode encontrar a consciência, é plausível assumir que quando alguém possui consciência das circunstâncias que envolvem um ato, pode-se afirmar que este ato é intencional, pois as conseqüências se desenrolaram de acordo com aquilo que se tem conhecimento. Portanto, no caso de um agente consciente produzir, como conseqüência de seu ato, mais dor do que prazer, chega-se à conclusão, de que sua intenção estava carregada de perniciosidade.

A faculdade intelectiva (consciência) de um indivíduo, desta forma, refere-se às conseqüências (e, portanto à produção de prazer ou dor) na medida em que conhece, não conhece ou pensa conhecer as circunstâncias que circundam um ato.

Este constitui um importante recurso metodológico para verificar se um ato é pernicioso ou não, pois quando fica provado, por meio de provas materiais, que um indivíduo não possuía conhecimento das circunstâncias em que um determinado ato transgressor ocorreu, talvez não haja razões para puni-lo. Ou seja, a proporcionalidade entre crime e punição refere-se a impedir a ocorrência de crimes futuros. Portanto, se o agente não cometeu uma determinada infração, conscientemente, talvez não seja necessário efetuar punição.

Entendida a relação dos componentes metodológicos que acompanham a ação (ato, circunstância, intenção e consciência) com as conseqüências e, portanto com a geração de prazer ou dor, resta saber, para análise da tendência geral do ato, quais são as influências de outros instrumentos metodológicos denominados motivos e disposição na produção de conseqüências.

Segundo Bentham, qualquer ato assume um caráter diferente, dependendo da natureza dos motivos. Nisto reside a importância de se analisar os vários motivos pelos quais a conduta humana pode ser influenciada. Por motivo entende-se qualquer causa que possa contribuir para produzir ações ou evitá-las. Ele dá origem a um prazer ou dor, ou outro 
acontecimento que dispõe para a ação ${ }^{48}$. Reitera-se, assim como para os outros instrumentos metodológicos, que alguém que se dirige por um motivo deve voltar-se, necessariamente, para as conseqüências do ato, pois só desta maneira terá idéia do prazer e dor que se seguirá.

Geralmente, ou popularmente, segundo o autor, são dados dois significados à palavra motivo, a saber: a) usado para designar qualquer fator que origina um ato (este é o sentido não figurado, real) e b) ou expressa uma paixão (este é seu sentido figurado) ${ }^{49}$. Considerando-se o seu primeiro significado, qual seja: motivo como fatos que originam um ato, diz-se que podem ser nomeados de duas formas: 1) devido à percepção interna de prazer e dor resultante da ação (motivos internos) e 2) ou evento externo que pode provocar a percepção de prazer ou dor (motivos externos).

Além de poder serem originados por fatos internos ou externos, os motivos podem ser de dois tipos: a) motivo em perspectiva (ato futuro) que se espera em perspectiva após a ação) podem ser internos ou externos, b) motivo in esse (evento que se realiza quando uma pessoa aguarda outro fato em perspectiva, ou seja, enquanto o indivíduo espera algo em perspectiva, ele antecipa o sentimento de prazer ou dor) que podem ser apenas internos.

Os motivos, como qualquer outro recurso metodológico utilizado pelo autor para entender as conseqüências das ações, não podem ser ditos bons ou maus em si mesmos, somente a dor e o prazer são ditos maus ou bons em $\mathrm{si}^{50}$. Se, em um certo sentido, os motivos são ditos

\footnotetext{
${ }^{48}$ A respeito disto cito Jeremy Bentham em Uma Introdução aos Princípios da Moral e da Legislação p. 34: “[...] Por motivo, no sentido mais vasto em que o termo é usado com referência a um ser pensante, designa-se qualquer coisa que possa contribuir para produzir qualquer espécie de ação, ou mesmo para evitá-la ou impedi-la [...]".

${ }^{49}$ Sobre isto cito Jeremy Bentham em Uma Introdução aos Princípios da Moral e da Legislação p. 35: “[...] Em certas ocasiões o termo motivo é usado para designar qualquer um dos fatores realmente existentes, dos quais se supõe que o ato em questão se origina. Temos, neste caso, a palavra motivo usada no seu sentido literal ou não figurado. Em outras ocasiões o termo é empregado para designar uma certa entidade fictícia, uma paixão, um estado da mente, um ser ideal que, ao acontecer um tal fato, é considerado como exercendo influência sobre a mente e a disposição de tomar aquela decisão para a qual é impelida pela influência de tal fato. [...] Neste caso temos o termo" motivo" empregado em seu sentido figurado [...]".

${ }^{50}$ No capítulo terceiro será discutido, de maneira mais detalhada, de que forma pode-se dizer que um o prazer pode ser entendido como bem e de que forma a dor pode ser entendida como mal.
} 
bons ou maus o são, exclusivamente, com respeito à tendência que possuem de produzir prazer ou dor, em determinada circunstância. Em outras palavras, um mesmo motivo, dependendo da circunstância e do indivíduo que age, pode originar atos bons (que proporcionam prazer) ou maus (que propiciam desprazer) $^{51}$.

Assim, motivo em sentido bom proporciona prazer, motivo em sentido mau gera desprazer, motivos que provocam ações indiferentes do ponto de vista do prazer ou dor, são ditos neutros, seguindo o princípio da utilidade (regra que enuncia que aquilo que importa é cômputo de prazeres e dores). Abaixo seguem exemplos de vários sentidos (bons, maus ou neutros) que podem assumir um mesmo motivo, dependendo do prazer ou dor que segue do ato influenciado por ele ${ }^{52}$.

Aos prazeres derivados do sentido sexual corresponde um motivo que em sentido neutro é denominado desejo sexual. Em mau sentido tal motivo é chamado de luxúria e tantas outras variedades de nomes relacionados à reprovação. Em bom sentido não existe termo para designá-lo. Em todos os casos (bom, mau ou neutro) o motivo é o mesmo, qual seja: desejo sexual.

No que concerne aos prazeres da riqueza (interesse pecuniário), verifica-se a associação de um motivo que pode ter vários sentidos: 1) em sentido neutro se denomina parcimônia, 2) com significado mau é nomeado avareza e cobiça e 3) em sentido de economia e

\footnotetext{
${ }^{51}$ A respeito disto cito Jeremy Bentham em Uma Introdução aos Princípios da Moral e da Legislação p. 37: “[...] Ora, o prazer é em si mesmo um bem - não só isto, mas até o único bem, abstraindo da imunidade da dor: e a dor é em si mesma um mal - não só isto, mas o único mal, sem exceção. De outra forma, as palavras bem e mal não têm nenhum significado. Ora, o que acabamos de dizer é igualmente verdadeiro com relação a qualquer espécie de prazer. Donde se infere, de maneira imediata e incontestável, que não existe nenhuma espécie de motivo que seja em si mesmo (intrinsecamente) mau [...]”.

${ }^{52}$ Sobre isto cito Jeremy Bentham em Uma Introdução aos Princípios da Moral e da Legislação p. 37: “[...] Se os motivos são bons ou maus, será exclusivamente em razão dos seus efeitos: serão bons em razão da tendência que têm a produzir prazer ou a impedir a dor: serão maus em razão da tendência que têm a produzir dor ou a afastar o prazer. Ora, é um fato que do mesmo motivo, e de cada espécie de motivo, podem derivar ações que são boas, outras que são más e outras que são indiferentes [...]".
} 
frugalidade é dito bom. O mesmo motivo, interesse pecuniário, pode ter um neutro, mau e bom sentido.

Com respeito aos prazeres da amizade (desejo de captar afeição particular), corresponde um motivo que pode ter um sentido bom, neutro ou mau: 1) em má acepção é chamado servilismo (proporcionar prazeres a outros mais poderosos), 2) em bom sentido denomina-se benevolência, simpatia (particular) e 3) em sentido neutro chama-se captar afeição. Apesar de significados diferentes, estas são todas facetas de um mesmo motivo (desejo de captar afeições particulares).

Sobre os prazeres derivados da boa reputação (ou sanção moral) também corresponde um motivo que pode ter um sentido bom, neutro ou mau: 1) com significado bom denomina-se honra, 2) em sentido neutro é chamado desejo de captar afeição do mundo (mais amplo do que os prazeres da amizade), 3) em mau sentido diz-se que corresponde à falsa fama, orgulho ou vaidade e ambição e 4) em casos particulares este motivo é designado amor à glória. Estes são prazeres conexos à sanção moral e levam à dores derivadas da mesma fonte, como medo da desonra, medo da vergonha e medo da desconsideração. Contudo, em todos os casos o motivo é o mesmo, qual seja: amor à reputação.

Aos prazeres do poder se associa, em um sentido neutro, o amor ao poder. O amor à reputação e ao poder tem íntima relação e por isto o bom e mau sentido de cada um deles coincide.

A sanção religiosa também gera prazeres e dores: 1) em bom sentido chama-se devoção, piedade, zelo, 2) em um mau sentido denomina-se zelo entusiástico, fanatismo, superstição. Nos dois casos o motivo é exatamente o mesmo, referente à sanção religiosa.

No que concerne aos prazeres da simpatia (benevolência ou boa vontade), ressaltase que estão associados os seguintes significados: 1) em bom sentido e neutro denomina-se boa 
vontade, benevolência, humanismo, amor fraterno (mais amplo do que a benevolência referente ao desejo de amizade) e 2) em mau sentido chama-se parcialidade. Isto mostra que o motivo da simpatia, dependendo das conseqüências que produz (prazer e dor) pode ter um significado, totalmente, distinto.

Aos prazeres da antipatia ou malevolência corresponde um motivo que também pode ter significado bom, mau ou neutro, a saber: 1) em sentido neutro denomina-se antipatia ou desprazer, aborrecimento, 2) com significado mau fraco chama-se má vontade, raiva, inimizade, 3) em sentido mau forte diz-se que é furor, mau humor, ódio, malícia, crueldade, tirania, inveja, ciúme, vingança e 4) com acepção boa diz que a antipatia é justa e louvável. Em todos estes casos o motivo é o mesmo: qual seja, má vontade ou malquerença. A única diferença reside nas conseqüências que tendem a produzir (boas ou más).

A todas as dores que possam significar o fim de nossos prazeres, corresponde o motivo que em sentido neutro denomina-se auto-preservação (desejo de defender-se da dor em questão). Não há sentido mau dado à auto-preservação uma vez que ela tem por objetivo evitar a dor. Ou seja, a conexão deste motivo com as conseqüências das ações têm em vista uma boa causa, pois pretende evitar a dor.

Ao mau da morte que também significa o fim de nossos prazeres, corresponde um motivo que em sentido neutro chama-se amor à vida. Este motivo em sentido mau denomina-se covardia. Às dores do esforço que possuem o mesmo sentido de cessar prazeres, corresponde um motivo que em sentido neutro denomina-se amor ao sossego ou desejo de não ser incomodado, com mau significado chama-se indolência e em bom sentido não há termo para expressá-lo.

Desta descrição dos vários tipos de motivos das ações, é possível concluir que não há nenhuma espécie de motivo que seja má em si mesma, como tampouco existe motivo que seja exclusivamente bom. Conforme demonstrado, este recurso metodológico denominado motivo por 
vezes é considerado bom, por vezes é dito indiferente e por vezes é avaliado como mau, pois esta classificação entre (bom, mau ou indiferente) depende, exclusivamente da relação que possui com a geração de prazer e dor (conseqüências).

Assim, se algum motivo for bom ou mau o é, apenas, em razão de seus efeitos. Esta consideração ocorre, exclusivamente, devido à ocorrência de circunstâncias particulares e com motivos particulares. Conseqüentemente, se algum motivo, em razão dos seus efeitos, pode ser qualificado de mau, com alguma propriedade do termo, só pode ser assim denominado com referência ao balanço de todos os seus efeitos ${ }^{53}$. Porém, objetar-se-á: mas a luxúria, a avareza e a crueldade não constituem motivos maus em si mesmos? A resposta para esta pergunta refere-se ao fato de que estes não são motivos, mas sim efeitos dos motivos intitulados desejo sexual, pecuniariedade e antipatia.

O autor ressalta que apesar de ter exposto o arranjo de situações em que um mesmo motivo pode ser considerado bom, mau ou neutro, isto pode ser considerado imperfeito, pois um motivo só pode ser classificado como bom ou mau dependendo de seus efeitos em cada caso individual e da intenção (que se relaciona com a perniciosidade do ato) originada pelos motivos $^{54}$. Ou seja, mais uma vez reitera-se a importância de relacionar-se este recurso com as conseqüências das ações.

\footnotetext{
${ }^{53}$ A respeito disto cito Jeremy Bentham em Uma Introdução aos Princípios da Moral e da Legislação p. 46: “[...] Face a tudo o que acabamos de expor, conclui-se que não existe nenhuma espécie de motivo que seja má em si mesma, como tampouco existe motivo algum que seja em si mesmo exclusivamente bom. No que concerne aos seus efeitos, é igualmente manifesto que estes por vezes são maus, por vezes bons ou indiferentes. É evidente também que isto acontece com qualquer espécie de motivo. Por conseguinte, se algum motivo for bom ou mau em razão dos seus efeitos, isto acontece exclusivamente em se tratando de ocasiões particulares, e com motivos particulares, e isto acontece com qualquer motivo [...]".

${ }^{54}$ Sobre isto cito Jeremy Bentham em Uma Introdução aos Princípios da Moral e da Legislação p. 48: “[...] Ao que parece, a única maneira segundo a qual um motivo pode com certeza e propriedade de linguagem ser qualificado bom ou mau, é com referência aos seus efeitos em cada caso individual, e, sobretudo a partir da intenção que deriva do respectivo motivo, da qual nasce, como demonstraremos abaixo, a parte mais importante dos seus efeitos [...]".
} 
Seguindo um método para distribuir os motivos segundo a tendência que possuem a harmonizar os interesses de um indivíduo com os da comunidade (soma de indivíduos), ou de fazer conflitar estes interesses ${ }^{55}$, os motivos podem ser separados em sociais, dissociais ou pessoais.

Os motivos sociais (other-regarding) são os que possuem a maior tendência a fazer convergir os interesses da sociedade com os do indivíduo. Podem ser agrupados em: a) boa vontade ou benevolência (ou simpatia e amor à amizade em bom sentido), b) amor à reputação (captar afeição em sentido amplo), c) desejo de amizade (captar afeição particular) e d) religioso. É importante notar que apenas ao motivo da benevolência pode-se aplicar a qualidade de ser puramente social, pois os motivos referentes ao amor à reputação, desejo de amizade e à religião apresentam uma tendência social menos constante, quando comparados à benevolência. Por isso, estes motivos últimos motivos seriam denominados, com maior propriedade, semi-sociais.

Os motivos que possuem a maior tendência a fazer divergir os interesses sociais com os do indivíduo são denominados motivos dissociais. Estes resumem-se, especialmente, ao motivo denominado desgosto ou antipatia. Os motivos que possuem a maior tendência a referirem-se, somente, aos indivíduos são chamados pessoais (self-regarding). São eles: desejo físico (ou sexual), interesse pecuniário, amor ao poder e autopreservação (incluindo temor das dores dos sentimentos, o amor ao sossego e o amor à vida).

Apesar desta classificação de motivos sociais, o modelo de indivíduo (autointeressado) adverte que os interesses da própria pessoa não podem ficar de fora de consideração. Isto, contudo, não impede que os interesses do resto da comunidade sejam levados em conta.

\footnotetext{
${ }^{55}$ A respeito disto cito Jeremy Bentham em Uma Introdução aos Princípios da Moral e da Legislação p. 48: “[...] Em conseqüencia do que dissemos, pareceria que um método mais cômodo seria distribuir os motivos conforme a influência que têm sobre os interesses dos outros membros da comunidade, deixando à parte os interesses da pessoa particular: em outros termos, segundo a tendência que têm no sentido de harmonizar os interesses da pessoa com os da comunidade, ou de conflitar uns com os outros [...]".
} 
Tendo em vista estes fatores, Bentham classifica os motivos segundo a aproximação/distância que possuem do princípio da utilidade.

Segundo o autor, de todas estas espécies de motivos, o da boa vontade ou benevolência (ou simpatia em bom sentido) é aquele cujos ditames apresentam a maior certeza de coincidir com os motivos do princípio da utilidade ${ }^{56}$, isto porque, este motivo ensina que é necessário gerar prazer. Em outras palavras, se ao agir de acordo com a benevolência, o indivíduo, que pratica o ato, obtiver prazer, certamente não ocasionará dor para aquele que é afetado por ele, pois este motivo da ação está, em todos os casos, de acordo com o princípio da benevolência pública ${ }^{57}$. Assim, o autor conclui, explicitamente, que os ditames da utilidade coincidem com os ensinamentos da benevolência ${ }^{58}$.

O segundo tipo de motivo, que mais ajusta-se ao princípio da utilidade, é o amor à reputação, pois, quando empregado em bom sentido, tem a tendência de fazer bem aos outros indivíduos. O amor à reputação só não coincide com o princípio da utilidade quando se deixa guiar pelo sentido mau do princípio da simpatia/antipatia. A seguir, o tipo de motivo mais próximo ao princípio da utilidade refere-se ao desejo à amizade.

O amor à reputação e o desejo de amizade têm disposição para coincidir com os ditames da utilidade, na medida em que coincidem com a benevolência (simpatia em bom sentido). Contudo, a amizade cuida de um número menor de pessoas do que o amor pela reputação, e por isso vem atrás dele na conformidade com o princípio da utilidade.

Os ditames da religião se igualariam ao princípio da utilidade caso a noção que as pessoas tivessem acerca do ser supremo se assemelhasse à benevolência. Contudo, os religiosos

\footnotetext{
${ }^{56}$ Este tema será melhor explorado no capítulo terceiro deste trabalho.

${ }^{57}$ Entenda-se benevolência pública como a geração de mais prazer do que dor no cômputo geral do balanço.

${ }^{58}$ Sobre isto cito Jeremy Bentham em Uma Introdução aos Princípios da Moral e da Legislação p. 49: "[...] $O$ que faz os ditames da benevolência privada serem conformes, em seu conjunto, ao princípio da utilidade é o fato de não serem em geral contraditos pelos ditames da benevolência pública: caso lhes sejam contrários, será apenas acidentalmente [...]".
} 
nem sempre dão o mesmo sentido de benevolência a Deus. Caso o dessem haveria convergência entre o princípio da utilidade e os ditames da religião. $\mathrm{O}$ autor ressalta que a religião, quando não coincide com o princípio da benevolência pública ou princípio da utilidade (procurar ocasionar mais prazer do que dor) segue: ou o princípio da antipatia/simpatia utilizado em mau sentido (malevolência ou parcialidade) ou o princípio do ascetismo (busca da dor).

Os motivos sociais, acima descritos, são os que mais possuem a tendência de coincidir com o princípio da utilidade, pois são os que possuem a maior probabilidade de ocasionar mais prazer do que dor para o maior número possível de pessoas ${ }^{59}$, no cômputo geral do balanço entre prazer e dor. A despeito disto, um motivo dissocial também pode possuir uma tendência social, pois, por exemplo: o desgosto que é visto, normalmente, como motivo dissocial pode tornar-se social quando transforma-se em descontentamento em relação a uma injustiça cometida a um grupo de pessoas. Em alguns casos, tal motivo pode ser mais social do que a benevolência. Apesar disto, os motivos que tendem a coincidir mais freqüentemente com o princípio da utilidade são os sociais, pelo número maior de pessoas que tendem a causar benefício (mais prazer do computo geral).

No que concerne à ordenação entre os motivos de natureza pessoal (self-regarding) diz-se que eles também estão de acordo com os ditames da utilidade, pois concorda com modelo de indivíduo de Bentham, qual seja: o indivíduo é auto-interessado, busca prazer e foge da dor, ou seja, procura, em todos os casos, maximizar seus interesses ou sua utilidade. Estes motivos deixam de coincidir com os ditames da utilidade quando os interesses individuais entram em conflito com os interesses da comunidade, pois neste caso, mais dor será ocasionada do que prazer, no cômputo geral do balanço de prazer e dor.

\footnotetext{
${ }^{59}$ Faz-se necessário não esquecer o modelo de indivíduo que enuncia que os interesses do agente não ficam de fora da sua ação.
} 
Desta análise dos tipos de motivos e sua agregação em motivos sociais, dissociais e pessoais, é possível depreender que o autor cria um recurso metodológico para estabelecer, com clareza, quais as relações que este instrumental pode apresentar com o princípio de utilidade ou com as conseqüências das ações (entenda-se, sempre, geração de prazer ou dor). Em todos os capítulos deste trabalho, será feita referências a esta agregação dos motivos em sociais, dissociais e pessoais para relacioná-la com a possibilidade ou não de geração de prazer ou dor.

Assim, tendo em vista quais podem ser os tipos de motivos e suas relações com o princípio de utilidade, é criado mais um instrumento metodológico para classificar os motivos conforme possuam caráter impulsionador ou demovente de uma ação. Em outros termos, os motivos segundo estejam em direções contrárias, com relação a uma mesma ação, são denominados impulsionantes, quando contribuem para ocasionar uma ação e demoventes quando não dispõem a empreender um determinado ato.

Portanto, entendidas as relações que o instrumento metodológico denominado motivo pode ter na produção de conseqüências das ações e, desta forma, na geração de prazer ou dor, outro recurso de sua metodologia é descrito, a saber: a disposição. Este instrumento é denominado, pelo autor, como algo que parece ser mais permanente na estrutura da inteligência de uma pessoa.

O autor argumenta que a disposição é um ente fictício, um recurso metodológico construído para entender o que se supõe ser permanente na estrutura de inteligência de uma pessoa $^{60}$. Ou seja, mais um instrumento é criado em sua metodologia, com o objetivo de fazer suposições sobre aquilo que parece mais constante no caráter de um indivíduo. A necessidade de

\footnotetext{
${ }^{60}$ Sobre isto cito Jeremy Bentham em Uma Introdução aos Princípios da Moral e da Legislação p. 56: "[...] $A$ disposição é uma espécie de ente fictício, criado para a conveniência do discurso, com o objetivo de exprimir, o que se supõe ser permanente na estrutura ou inteligência de uma pessoa, onde, nesta ou naquela ocasião, ela foi influenciada por este ou por aquele motivo a praticar um ato que se apresentava a ela com esta ou aquela tendência $[\ldots] "$.
} 
construir este recurso metodológico, refere-se à importância de prever a constância das conseqüências das ações dos agentes.

Segundo o autor, partindo do grau de constância e uniformidade que, segundo a experiência, se pode observar, nas diferentes ações de uma mesma pessoa, conclui-se para a existência provável de uma série de atos de natureza semelhante nas futuras ações dos indivíduos. Portanto, se um motivo se mostrar tal em um caso e outro, e os atos se mostrarem parecidos quando este mesmo motivo se manifesta, presume-se que a disposição será idêntica em outros casos, na presença deste mesmo motivo. A natureza da disposição (boa ou má) depende, do grau de sensibilidade da pessoa em relação à força destes ou daqueles motivos (em bom ou mau sentido).

O recurso metodológico denominado disposição funciona como a soma das intenções de um agente, pois é como se intenções de mesma natureza se sucedessem em um longo período de tempo. Em outras palavras, a disposição que um agente possui durante um certo período representa o resultado das suas intenções no decurso do referido período. Se os atos perniciosos forem, proporcionalmente, muito mais numerosos, considerando um determinado período de tempo, então a disposição será avaliada como perniciosa ${ }^{61}$.

Assim, da mesma forma que os motivos, acontece com a disposição o que sucede com qualquer outro instrumento metodológico construído pelo autor: será considerado bom ou mau de acordo com seus efeitos, isto é, conforme as implicações que ocasionam quanto a aumentar ou a diminuir prazer e dor no indivíduo ou na coletividade ${ }^{62}$. Desta forma, a disposição pode ser vista sob dois pontos de vista, conforme a influência que tenha sobre a própria

\footnotetext{
${ }^{61}$ A respeito disto cito Jeremy Bentham em Uma Introdução aos Princípios da Moral e da Legislação p. 58: “[...] Com efeito, a sua disposição é como que a soma das intenções: a disposição que tem durante um certo período, a soma ou o resultado das suas intenções no decurso do referido período [...]".

62 Com respeito a isto cito Jeremy Bentham em Uma Introdução aos Princípios da Moral e da Legislação p. 56: "[...] Acontece com a disposição o que sucede com qualquer outra coisa: será boa ou má de acordo com os efeitos que tem quanto a aumentar ou diminuir a felicidade da coletividade [...]”.
} 
felicidade do indivíduo ou sobre a felicidade de outros ${ }^{63}$. Considerada sob esses dois aspectos, conjuntamente, ou sob um dos dois, a disposição pode ser denominada boa, má ou depravada em casos flagrantes.

Quando a disposição refere-se à própria felicidade do indivíduo, esta pode ser considerada frágil (quando possui a tendência a gerar mais dor do que prazer ao indivíduo) ou firme (quando tende a ocasionar mais prazer do que dor ao indivíduo em questão). Enquanto refere-se à felicidade dos outros a disposição pode ser denominada benéfica e meritória (quando gera mais prazer) ou perniciosa e prejudicial (quando ocasiona mais dor).

Com respeito à disposição, quando se refere apenas à própria felicidade do indivíduo, o autor ressalta que cabe mais ao moralizador reformá-la do que ao legislador, uma vez que não ocorre interação entre os indivíduos, dado que outros agentes não são afetados por esta disposição. Segundo Bentham, a influência em relação a um maior número de pessoas se dá quando a disposição refere-se à felicidade dos outros, em outras palavras, quando ela é passível de gerar dor ou prazer em outros indivíduos. Por esta razão, será este tipo de disposição que o autor analisa, enquanto causadora de conseqüências ${ }^{64}$.

Restará claro no capítulo terceiro e quarto deste trabalho que embora em alguns momentos o autor faça referência ao moralizador como se tivesse um papel de natureza distinta do legislador, isto é apenas um argumento retórico, pois o moralizador, assim como o legislador

\footnotetext{
${ }^{63}$ Remete-se, aqui, aos tipos de ações descritos pelo autor. De um indivíduo para consigo, de um indivíduo para com os outros de forma positiva (quando gera prazer) e de um indivíduo para com os outros de forma negativa, quando abstém-se ou não de ocasionar dor.

${ }^{64}$ Sobre isto cito Jeremy Bentham em Uma Introdução aos Princípios da Moral e da Legislação p. 56-57: “[...] quanto àquele aspecto da disposição de uma pessoa, cujos efeitos se relacionam em primeira e direta instância exclusivamente com a própria pessoa, não é necessário dizer muito neste contexto. Compete mais ao moralista do que ao legislador reformá-la quando for má: tampouco é ela suscetivel daquelas várias modificações que perfazem uma diferença tão relevante nos efeitos da outra. Com respeito àquela parte da disposição, cujos efeitos afetam outros na primeira instância, é somente na medida em que ela revestir uma natureza má ou perniciosa que o setor penal da lei tem uma relação imediata com ela: na medida em que for de natureza benéfica, pertence a um setor da lei que até agora tem sido muito pouco cultivado e ainda carece de denominação própria, que poderíamos denominar o remuneratório[...]".
} 
deve utilizar o princípio de utilidade para efetuar seus julgamentos. Ou seja, considerando prazer e dor como aquilo que importa do ponto de vista da utilidade, será mostrado nos capítulos subseqüentes que não há diferença de natureza entre a moral e a legislação.

Tendo a consideração acima em vista, volta-se à análise da disposição como recurso metodológico para que se compreenda as conseqüências de uma ação.

Quando a disposição gera efeitos que afetam os outros, esta só possui relação com o setor penal se for má ou perniciosa, se for de natureza benéfica, poder-se-ia denominá-la remuneratória. Desta forma, diz-se que uma pessoa tem disposição má quando por influência de qualquer motivo está mais inclinada, de maneira permanentemente, a praticar atos que, aparentemente, se caracterizam com uma tendência perniciosa.

Conforme dito acima, se um determinado indivíduo, em determinadas ocasiões, na presença de um mesmo motivo, tende, freqüentemente, a realizar atos perniciosos, diz-se que a disposição do indivíduo em relação àquele motivo é má. Assim, quando o ato for de natureza perniciosa, o motivo que tende a provocar este ato é dito sedutor ou corruptor, neste caso, qualquer motivo que for demovente ao sedutor será denominado motivo preservador.

É importante atentar para o fato de que o autor introduz um novo instrumento metodológico, pois considera que os motivos que demovem um indivíduo, com disposição perniciosa, de praticar atos prejudiciais são denominados preservadores.

Uma subdivisão adicional de sua metodologia sobre os motivos é efetuada, pois os motivos preservadores também podem ser de vários tipos, quais sejam: a) permanentes quando agem com grande força no que diz respeito à tendência a demover uma pessoa de quaisquer atos perniciosos que sua disposição possa aproximar-se de praticar (isto ocorre com uma eficácia que depende mais da natureza geral do ato do que de circunstâncias ocasionais) e b) ocasionais 
quando podem agir ou não em direção contrária aos motivos sedutores, de acordo com a natureza do ato e da ocasião particular.

Todos os motivos podem dispor as pessoas a praticar atos maus, mas alguns têm maior probabilidade de serem motivos preservadores (que demovem o indivíduo de efetuar atos nefastos) e outros de serem sedutores (que tendem a fazer com que as pessoas executem ações prejudiciais). Esta subdivisão de motivos, entre sedutores e preservadores, constitui, mais uma vez, um recurso metodológico que viabiliza a comparação da disposição do agente com a classificação de motivos entre sociais, dissociais e pessoais.

Disto conclui-se que os motivos sociais têm maior probabilidade de serem preservadores, pois agem contra os motivos sedutores independentemente das circunstâncias particulares. Os motivos da benevolência ou boa vontade podem ser catalogados na categoria dos motivos permanentes preservadores, pois constituem o bom sentido dos prazeres da simpatia. A mesma observação pode ser feita, no que concerne ao motivo semi-social do amor à reputação, pois é possível ser colocado na qualidade de motivos permanentes preservadores. É importante verificar que este motivo entra nesta categoria, pois o amor à reputação constitui uma preocupação constante dos membros de uma comunidade, dado que a sanção moral é uma importante fonte de geração de prazer ou dor. Ou seja, ocorre a preocupação com este motivo, porque a reputação depende dos outros, conseqüentemente se um ato pernicioso é realizado, em nome da reputação, ao menos alguns olharão com desaprovação. O mesmo acontece com a amizade. Ela constitui um motivo permanente preservador, pois a força com a qual se aplica não depende das circunstâncias ocasionais, mas sim da constância ocasionada pela aprovação ou reprovação da sanção moral.

A força da religião não representa um motivo que apresenta constância quanto às conseqüências que gera, pois às vezes se opõe aos motivos sedutores, gerando conseqüências que 
concordam com o princípio de utilidade, às vezes concorda com os motivos sedutores, ocasionando conseqüências contrárias à geração de prazer e dor. Ainda sim, pode ser chamado de motivo preservador permanente, pois quando atua em oposição aos motivos sedutores comuns, atua como motivo da benevolência e não se modifica com as circunstâncias particulares.

Pode-se dizer que todos os motivos têm a capacidade de serem chamados de ocasionalmente preservadores, uma vez que quase todos eles possuem um bom sentido. Ou seja, é possível associar um sentido de harmonização social a praticamente todos os motivos. Os principais motivos preservadores ocasionais são: o amor ao sossego e a auto-preservação. Eles opõem-se a ocasionais perigos que podem ser de natureza física ou de natureza moral. Estes motivos são chamados preservadores ocasionais, pois agem, apenas, quando há perigo de detecção do crime passível de sanção moral.

Com esta noção de perigos de detecção, o autor constrói um outro instrumento metodológico capaz de explicar porque, em algumas circunstâncias, alguns motivos (como amor ao sossego e auto-preservação) harmonizam-se com os interesses da comunidade. Ou seja, os perigos da detecção (que podem ser realizados por meio da sanção moral ou por meio dos riscos de punição) fazem com que motivos das ações, que não necessariamente são sociais, entrem em acordo com os interesses da sociedade. Este acordo é benéfico, pois, como tem-se reiterado, possui a capacidade de produzir conseqüências em termos de prazer e dor.

Este outro instrumento metodológico, nomeado perigo de detecção, adicionado por Bentham, é subdivido em dois tipos: a) ao risco que pode resultar de qualquer oposição que possa ser feita ao ato, imediatamente e b) ao perigo que diz respeito à punição legal ou a outro sofrimento, ainda que longínquo, ao final do ato ${ }^{65}$.

\footnotetext{
65 Há dois motivos preservadores permanentes que dependem da detecção, embora não com a mesma força dos motivos ocasionais. Esses dois são o amor à reputação e à amizade. Tais motivos se aplicarão em maior força na
} 
Assim, tendo em vista os motivos que podem funcionar como sedutores ocasionais ou permanentes (tendem para a realização de um ato pernicioso) e os motivos que agem como preservadores permanentes ou ocasionais, como forma de afastar a concretização de um ato criminoso, o autor passa a levantar maior número de instrumentos, dentro de sua metodologia (heurística positiva), para operacionalizar os critérios que definirão o grau de perniciosidade da disposição. Estes instrumentos são relevantes, pois fornecem maior clareza acerca do grau de predisposição do agente a novamente cometer transgressões. Ou seja, os novos instrumentos metodológicos introduzidos, pelo autor, mais uma vez, justificam-se, pois são recursos para facilitar a compreensão da potencialidade de geração de prazer ou dor. Como objetivo final da criação destes instrumentos, tem-se a tentativa de impedir a geração de dor ou maximizar a felicidade da comunidade.

O novo instrumento para operacionalizar critérios de nocividade da disposição, apresentado por Bentham, é denominado força da tentação. Este recurso depende da relação existente entre a força dos motivos sedutores e a força dos motivos preservadores ocasionais (reitera-se que estes são provocados pelas circunstâncias do caso). A tentação é dita ser forte se os prazeres advindos do crime forem muito maiores do que o incômodo do perigo de detecção. A tentação é chamada fraca, quando os prazeres da transgressão são pequenos em comparação com o risco de ser detectado. A força da tentação não depende da força dos motivos em seu conjunto, mas sim das circunstâncias, pois está sujeita ao momento em que a oportunidade aparece como favorável, ou seja, é dependente da ocasião em que o perigo torna-se menor.

Este instrumento metodológico pode ser representado pela seguinte fórmula: Força da tentação $(\mathrm{FT})=$ Força dos motivos sedutores - Força dos motivos preservadores ocasionais.

medida em que tiverem maiores chances de serem detectados. Os motivos da benevolência e religião, contudo, não dependem do perigo da detecção. 
Esta fórmula representativa deste recurso (intitulado força da tentação) indica que um indivíduo cometerá uma transgressão, caso a força dos motivos sedutores for maior do que os motivos que o indivíduo possui para preservar seus interesses com os da comunidade. Ao contrário, se o indivíduo apresentar motivos preservadores com maior força do que os motivos sedutores, em uma dada circunstância, então, a transgressão não ocorrerá.

Desta observação da relação da força da tentação (FT) com os interesses da comunidade, pode-se efetuar comparação deste instrumento com os motivos sociais (MS). Se a força da tentação for maior do que os motivos sociais (ou motivos preservadores permanentes) presentes no indivíduo, então, provavelmente, determinado crime será cometido, caso contrário, a transgressão não será efetuada.

Contudo, indaga-se: qual é o critério que a força da tentação fornece, com respeito à perniciosidade da disposição do agente?

Diz-se que quanto mais fraca for a tentação a qual uma pessoa sucumbiu, mais perniciosa foi sua disposição, pois isto significa que a pessoa não precisou empregar empenho para livrar-se dos motivos sedutores, ou seja, este fator denota que a pessoa é pouco sensível a motivos sociais ${ }^{66}$. O grau de sensibilidade de uma pessoa em relação à força dos motivos sociais estará, portanto, em proporção com a perniciosidade aparente de tal ato. Quanto mais alta for a sensibilidade em relação aos motivos sociais, maior a tendência de um ato não ser pernicioso. Assim, caso um ato apareça como muito pernicioso a uma pessoa (ou seja, ela mesma o considera nefasto) e ela, ainda sim, o comete, então sua sensibilidade em relação às forças dos motivos sociais é baixa, a força da tentação é fraca, e sua disposição é dita ser má.

\footnotetext{
${ }^{66}$ A respeito disto cito Jeremy Bentham em Uma Introdução aos Princípios da Moral e da Legislação p. 62: “[...] Com efeito, a qualidade boa da sua disposição se mede pelo grau da sua sensibilidade em relação à influência dos motivos sociais: em outros termos, pela força da influência que esses motivos exercem sobre a pessoa: ora, quanto menor for a força que empregou para superar a influência desses motivos, tanto mais convincente é a prova fornecida para a fraqueza dessa influência [...]”.
} 
Desta forma, conclui-se que quanto mais fraca for a tentação, mais perniciosa e depravada é a disposição do agente que efetua crimes, pois isto indica que foram pequenos os esforços dos motivos sociais usados para vencer os motivos sedutores ${ }^{67}$. Assim, a força da tentação fraca ou pequena constitui prova convincente de que a influência ou sensibilidade de motivos sociais é reduzida no indivíduo criminoso ${ }^{68}$. Isto implica que o indivíduo desconsidera, ou pouco considera os interesses de outros indivíduos ${ }^{69}$.

Portanto, para avaliar a maldade da disposição de uma pessoa, a partir do instrumento/critério metodológico ${ }^{70}$ força da tentação, estabelecem-se as seguintes normas: a) uma vez conhecida a força da tentação, a maldade da disposição manifesta pelo ato estará em função da aparente perniciosidade dele, b) conhecendo-se a aparente perniciosidade de um ato, a disposição de uma pessoa é tanto mais depravada, quanto mais fraca for a tentação à qual sucumbiu. Os efeitos de tal disposição depravada, com respeito à parte do público afetado, estão na mesma proporção da fraqueza da força da tentação, c) uma vez conjecturada a perniciosidade do ato, a evidência que ela proporciona em prova da maldade da disposição de uma pessoa é tanto menos convincente, quanto mais forte for a tentação à qual a pessoa sucumbiu (isto indica forte presença ou sensibilidade dos motivos sociais no indivíduo), d) quando o motivo for do tipo dissocial, uma vez conhecidas a aparente perniciosidade do ato e a força da tentação, a maldade da disposição será proporcional ao grau de deliberação que o acompanha ${ }^{71}$. Esta norma, em outras palavras, quer dizer que quanto maior for o período de tempo durante o qual uma pessoa

\footnotetext{
${ }^{67}$ Sobre isto cito Jeremy Bentham em Uma Introdução aos Princípios da Moral e da Legislação p. 62: “[...] Com efeito, quanto mais fraca tiver sido a força da tentação, tanto menor foi a força que a influência dos citados motivos teve que vencer, e conseqüentemente mais convincente é a prova de que essa influência foi reduzida [...]”.

${ }^{69}$ Note-se que a tese de que o indivíduo é auto-interessado não é contraditória com o fato dos indivíduos poderem levar em consideração os interesses de outros indivíduos membros de uma comunidade.

${ }^{70}$ É, sempre, importante ter em vista que estes critérios são construídos para melhor controlar a compreensão das conseqüências das ações.

${ }^{71}$ Os motivos dissociais entram em ação, apenas em circunstâncias especiais.
} 
continua sob o domínio dos motivos dissociais, em uma determinada ocasião, tanto mais convincente será a prova da sua insensibilidade em relação à força dos motivos sociais ${ }^{72}$.

Não obstante a necessidade de todas estas normas e a verificação prática de que elas são necessárias para melhor avaliar os crimes que ocorrem, o autor ressalta que a natureza humana está orientada para o lado que nos conduz mais na direção de motivos sociais do que de motivos dissociais. Ou seja, mesmo levando em conta o modelo de indivíduo auto-interessado, enunciado neste capítulo, o autor acredita que é possível ${ }^{73}$ sua concordância com os interesses da comunidade. Sendo assim, o autor pensa que a força dos motivos sociais tende a eliminar a força dos motivos dissociais, pois o mais natural é que os indivíduos façam convergir seus interesses com os da sociedade. Por isto, quanto mais uma pessoa ficar sob o domínio de motivos dissociais em uma ocasião, maior será a prova de sua insensibilidade em relação à força dos motivos sociais e mais corrompida será sua disposição.

Tendo em vista a importância do instrumento metodológico nomeado disposição para determinar o grau de perniciosidade do ato, bem como a importância da construção do conceito de força da tentação para determinar o grau de sedução que um crime surte sobre um agente, o autor passa a utilizar estes elementos, dentre outros, na sua análise a respeito da punição de indivíduos.

Ou seja, levando em consideração o objetivo do autor (axiologia de fins) de proporcionar fundamentos para avaliar, de forma justa, ações condizentes com o modelo de

\footnotetext{
${ }^{72}$ A respeito disto cito Bentham em Uma Introdução aos Princípios da Moral e da Legislação p. 64: “[...] Em conseqüência, revela uma disposição mais depravada uma pessoa que elabora um plano deliberado para matar seu adversário, e o faz de acordo com o plano, do que se o matasse diretamente em conseqüência de uma rixa repentina: a disposição seria ainda mais depravada se, após tê-lo por muito tempo em seu poder, o mata a intervalos, quando tiver tempo [...]".

${ }^{73}$ A respeito disto cito Bentham em Uma Introdução aos Princípios da Moral e Legislação p. 63: “[...] A tendência geral e constante de cada ser humano está, pois,orientada para aquele lado, para o qual o conduz a força dos motivos sociais. Assim, a força dos motivos sociais tende continuamente a eliminar a dos motivos dissociais, da mesma forma que, nos corpos naturais, a força de fricção ou atrito tende a eliminar a força gerada pelo impulso $[\ldots]$ '.
} 
indivíduo (e portanto de acordo com o princípio da utilidade), dentro de uma sociedade (soma de indivíduos), Bentham utilizará a relação das conseqüências com todos os elementos metodológicos citados acima (ato, circunstância, intenção, consciência, motivos, disposição e força da tentação), para evitar, da melhor forma possível a perturbação da felicidade da comunidade através da punição ${ }^{74}$.

Estes elementos metodológicos, que constituem recursos para refinar e operacionalizar o princípio da utilidade e, portanto, para avaliar de maneira mais precisa as conseqüências das ações, servirão para analisar os casos em que cabe ou não punir um indivíduo, quando uma transgressão é gerada, bem como para avaliar a proporcionalidade entre as punições e os crimes. Este assunto será tratado, de forma mais sistemática, no capítulo quarto deste trabalho, contudo, adianta-se algumas normas e critérios utilizadas para a construção da legislação.

Um elemento fundamental para a compreensão de como se evita o mal em uma sociedade, refere-se às punições, pois elas são vistas, pelo autor, como um meio bastante eficiente de impedir que a felicidade (balanço entre prazer e dor) da comunidade seja diminuída. Contudo, toda punição é em si mesma um mal, dado que causa dor. Portanto, de acordo com o princípio da utilidade, considerado como uma regra que indica que o justo é que as conseqüências das ações devem proporcionar mais prazer do que dor, uma punição só pode ser admitida na medida em que evite um mal maior ${ }^{75}$.

\footnotetext{
${ }^{74}$ Sobre isto cito Bentham em Uma Introdução aos Princípios da Moral e da Legislação p. 65: “[...] O objetivo geral que caracteriza todas as leis - ou que deveria caracterizá-las - consiste em aumentar a felicidade global da coletividade: portanto, visam elas em primeiro lugar a excluir, na medida do possivel, tudo o que tende a diminuir tal felicidade, ou seja, tudo o que é pernicioso [...]".

${ }^{75}$ A respeito disto cito Bentham em Uma Introdução aos Princípios da Moral e da Legislação p. 65: “[...] Acontece, porém que toda punição constitui um ato pernicioso: toda punição constitui, em si mesma, um mal. Por conseguinte, com base no princípio da utilidade -se tal princípio tiver que ser admitido -, uma tal punição só pode ser admitida na medida em que abre chances no sentido de evitar um mal maior [...]".
} 
Tendo em vista este fator, há casos em que a punição não deve ser aplicada, pois o mal em efetuar tal punição supera os benefícios por ela gerados. Estes casos serão analisados, de forma mais precisa no capítulo quarto deste trabalho. Entretanto, apenas, anuncia-se, aqui, quais são eles: a) quando não houver um ato prejudicial (não há razão para punir) a punição é denominada infundada, b) quando a punição é ineficaz, ou seja, quando esta não pode evitar o prejuízo, c) quando a punição é não proveitosa, ou seja, quando ela é muito custosa ou o seu prejuízo é maior do que aquele que se quer evitar e d) quando a punição é desnecessária (ocorre quando o prejuízo pode ser evitado por outros meios menos custosos).

Levando em conta estes casos em que o balanço de prazer e dor aponta para a não aplicação de penas legais, indaga-se, então: como evitar estas transgressões? Será que a ética, a partir de suas regras morais, pode ter um peso importante para impedir estes eventos?

Estas respostas serão dadas no capítulo quarto do presente trabalho. O caminho para fornecê-las, certamente, seguirá o sentido de estabelecer os limites entre a ética e a legislação.

Não obstante enunciar-se, aqui, que este assunto será examinado no capítulo quarto, apresenta-se, brevemente, alguns critérios metodológicos e normas relacionados à construção da legislação. Antes de apresentá-los afirma-se que o objetivo das leis é evitar danos causados por um ato, quando houver benefício suficiente (punição mais vantajosa que prejuízo gerado por ela). Tendo em vista este fator, quando for vantajoso, do ponto de vista da sociedade, o legislador, baseado no princípio da utilidade, deve levar em conta quatro critérios para construções de normas metodológicas jurídicas, a saber: a) evitar, na medida do possível e na medida em que for benéfico, qualquer espécie de crime, b) se for inevitável que alguém cometa um crime, o objetivo é induzi-lo a cometer um delito menos pernicioso no lugar de um mais pernicioso, c) uma vez que o criminoso se decidiu por um crime particular, o objetivo é induzi-lo a causar o mínimo de prejuízo possível e d) o último objetivo é evitar o crime da maneira menos dispendiosa possível. 
Estes critérios, apontam para o fato de que aquilo que se pretende é impedir, de todas as formas possíveis os crimes. Nisto consiste, precisamente, a proporcionalidade entre crime e punição, pois o objetivo é sempre estabelecer uma pena suficiente, apenas, para evitar que crimes ocorram.

É importante atentar para o fato de que ao longo desta apresentação de instrumentos, recursos e critérios metodológicos, o autor os associa, sempre, como forma de atingir um objetivo, com vistas a melhor analisar as conseqüências das ações (balanço entre prazer e dor). Neste caso, destaca-se a importância da punição como forma de impedir que a felicidade da comunidade seja perturbada. A seguir, conforme se verá, o autor associa este recurso metodológico (punição) a seu, também, instrumento metodológico, denominado força da tentação, com vistas a criar normas de proporção entre crime e punição

Aos quatro critérios, acima descritos, correspondem as seguintes normas que regem a proporção entre punições e crimes: A primeira norma enuncia que o valor ou a gravidade da punição não deve ser, em nenhum caso inferior ao que for suficiente para superar o valor do benefício do crime, do ponto de vista de quem o pratica. Esta norma explicita que a força da tentação funciona como o benefício recebido pelo crime, assim, o quantum da punição deve aumentar na medida em que aumenta tal força. Quanto maior a força da tentação (FT), menos se pode dizer acerca da maldade da disposição.

Assim, na medida em que há ausência de agravante decorrente da maldade da disposição, no momento em que se pratica o ato (vale lembrar que a maldade da disposição ocorre quando a força da tentação é baixa, pois isto é um indício da fraqueza dos motivos sociais), a alta (FT) pode atuar como atenuante da exigência de punição, pois indica a baixa tendência que os indivíduos possuem de fazer concorrer seus interesses com os da comunidade. 
Contudo, ao mesmo tempo, a força da tentação não pode tornar a punição ineficaz, ou seja, a FT (ou benefício advindo do crime) não pode ser maior do que o quantum de punição $^{76}$, pois o objetivo da punição é evitar o crime e assim conservar a felicidade da comunidade. Em outras palavras, caso a força da tentação for maior do que a punição, o crime será praticado e ocorrerá crueldade para com o público que fica exposto ao criminoso.

Portanto, neste sentido, a disposição má (que ocorre quando o indivíduo comete um crime motivado por uma baixa força da tentação) tem um sentido mais de agravante da pena, pois é fruto da perniciosidade de um agente, expressa a frieza com se pratica determinada transgressão. $\mathrm{O}$ mesmo ocorre com a intenção do agente, pois se restar provado que um agente tinha consciência das circunstâncias que circundavam o ato, fica comprovado que sua intenção estava conforme as conseqüências perniciosas de determinado ato.

Sobre estas considerações reitera-se a importância de ter-se em vista que todos estes recursos metodológicos são formulados como forma de prever, prevenir e melhor entender as conseqüências de um ato. O mesmo ocorre para o caso da disposição e intenção. A partir da metodologia de Bentham, o que se quer é entender de que forma estes elementos podem incrementar a compreensão da produção de prazer ou e, especialmente, de dor (pois a esta referem-se as transgressões). Assim, a intenção e disposição dos agentes, apenas, terão espaço na avaliação das conseqüências, quando houver prova material de que são boas ou más, conforme já mencionado.

Tendo em vista estes elementos, prossegue-se a análise das normas sobre proporção entre crime e punição: a segunda norma revela que quanto maior for o prejuízo derivado do

\footnotetext{
${ }^{76}$ Sobre isto cito Bentham em Uma Introdução aos Princípios da Moral e da Legislação p. 67: "[...] Todavia, a força da tentação jamais pode atuar até ao ponto de indicar a propriedade de tornar a punição ineficaz, o que acontece com certeza quando o valor ou gravidade da punição for inferior ao nivel do aparente beneficio derivante do crime $[\cdots] "$.
} 
crime, maior será o preço que pode valer a pena pagar a partir da punição. Ou seja, o autor salienta o princípio da proporcionalidade entre os prejuízos e as punições.

A terceira norma ressalta que quando houver dois crimes em concorrência, a punição estabelecida para o crime maior deve ser suficiente para induzir uma pessoa a preferir o menor. A quarta norma estabelece que a punição deve ser regulada de tal forma que para cada crime particular e para cada nova parte ou etapa do prejuízo possa haver um motivo que proíba o criminoso de produzi-la. As quatro primeiras normas têm como objetivo demarcar limites para evitar a falta de punição legal.

A quinta norma revela que a punição não deve ser maior do que o necessário para que seja conforme as normas elencadas acima, esta norma visa a evitar excesso de punição. Por fim, a sexta norma explicita que a quantidade de punição, de fato, aplicada a cada criminoso deve ter relação com a quantidade de benefício que cada criminoso deseja auferir. Para elaboração desta norma, torna-se necessário levar em consideração as várias circunstâncias que influenciam a sensibilidade de cada indivíduo em relação aos motivos (esta norma se destina, principalmente, ao juiz e não ao legislador, pois é necessário que ele adapte-se o máximo possível às leis).

Com a descrição desta sexta norma para verificar a proporcionalidade entre crime e punição, adia-se a aplicação destes recursos metodológicos, especialmente, para o capítulo quarto, com objetivo de entender de que forma possível conservar a felicidade da comunidade. Através da ética? através da lei? qual o raio de ação de ambas? qual a distinção que apresentam? quais seus limites?

Antes de responder a estas perguntas, outras indagações surgem, pois há a necessidade que se entenda, de forma mais detalhada, o significado do princípio de utilidade. Esta necessidade surge pois tal conceito será central para o estabelecimento dos limites entre a ética e a legislação. As perguntas que se colocam referentes ao esclarecimento do que constitui 
este princípio são as seguintes: como entender o princípio de utilidade de Bentham? quais suas aplicações e implicações? de que forma é aplicado e operacionalizado? há algum debate metametodológico realizado entre o princípio de utilidade e outros princípios? de que forma ele se liga à moral?

Estes constituirão os temas dos próximos capítulos, ou seja, travar-se-á dois debates importantes, a saber: a) a importância do conceito do princípio da utilidade, suas aplicações, relações metametodológicas e implicações e b) o estabelecimento de limites entre a ética e a legislação, para entender o papel da moral na obra deste autor, bem como a solução que é dada para os casos em que não cabe punir.

Os debates propostos serão efetuados tendo, sempre, em vista: a) o núcleo da teoria de Bentham com suas teses epistemológicas, axiológicas e ontológicas, bem como o modelo de indivíduo, guiado pelo princípio da utilidade e b) instrumentos metodológicos (presentes na Lógica da teoria de Bentham), para realizar análises e operacionalizações do núcleo, referentes à solução de problemas dentro de uma sociedade (impedir, através de penas formais e informais, a diminuição da quantidade de prazer ou felicidade da comunidade),

Considerando estes elementos, parte-se para explorar as aplicações e implicações do princípio de utilidade de Jeremy Bentham. 


\section{Capítulo III}

\section{O Conceito de Utilidade de Bentham}

“(....) By the principle of utility is meant that principle which approves or disapproves of every action whatsoever, according to the tendency which it appears to have augment or diminish the happiness of the party whose interest in question: or, what is the same thing in other words, to promote or to oppose that happiness (...)”.

\section{J. Bentham}

An Introduction to the Principles of Morals and Legislation, p. 1. 


\subsection{Introdução: Objetivos do Capítulo}

Neste capítulo pretende-se explicar a concepção de Bentham sobre o princípio de utilidade, bem como mostrar algumas de suas aplicações e implicações. A estratégia para a compreensão desta proposta será conduzida, inicialmente, a partir da exposição e interpretação do princípio de utilidade do autor. Seguindo esta mesma linha, as duas próximas seções representam explicações ou algumas saídas para problemas tradicionalmente levantados por críticos do utilitarismo de Bentham. Na primeira delas, realizar-se-á uma breve discussão sobre o problema da minoria como implicação decorrente da concepção do princípio de utilidade de Bentham. Na segunda, pretende-se mostrar que este princípio não converge para o egoísmo, mas sim para o motivo da ação denominado benevolência.

Efetuado este debate acerca das decorrências da concepção do princípio de utilidade de Bentham pretende-se apresentar em nível Histórico e Lógico a contextualização em que o autor cria o princípio. Será mostrado que o princípio de utilidade é colocado como uma diretriz metodológica para elaborar respostas às concepções políticas, por ele denominadas conservadoras e anárquicas. O princípio de utilidade permitirá elaborar uma concepção, inclusive de governo, que seja um meio-termo, uma solução, entre o conservadorismo e a anarquia.

Dentro deste escopo, o autor fará pesadas críticas à declaração francesa dos direitos naturais inalienáveis do homem, bem como efetuará oposição a princípios conservadores, fundados em alicerces subjetivistas, ditos causadores de conseqüências nefastas para os indivíduos (o princípio da simpatia constitui um exemplo deste tipo de princípio). Nesta mesma seção, travar-se-á um breve debate metametodológico entre o princípio de utilidade e os princípios da simpatia e ascetismo. 
Após ser demonstrado que a concepção do princípio de utilidade de Bentham representa um recurso metodológico para construir uma concepção que seja um meio-termo entre conservadorismo e anarquia, pretende-se efetuar algumas aplicações do princípio com vistas a entender sua posição frente à manutenção de promessas e ao contrato original, bem como será dada resposta à forma de governo que constitui, para o autor, o meio-termo entre anarquia e o conservadorismo. Será mostrado que a forma de governo que melhor explicita o princípio de utilidade e afasta-se do conservadorismo e anarquia é a democracia.

A seguir, procurar-se-á entender como este princípio se relaciona com a moral e como esta se distingue da ética. Tendo em vista o que constitui moral, para o autor, e sua relação com a ética, tenciona-se, no tópico seguinte, apontar quais são as causas da imoralidade apresentadas por este autor, ou seja, o que é visto como imoral, de acordo com seu sistema.

As causas da imoralidade constituem a razão pela qual atos danosos são causados a outros indivíduos. Contudo, questiona-se: quais os recursos utilizados para sanar estes prejuízos sociais? A partir da leitura do capítulo segundo, sabe-se que a legislação aliada a todos os recursos metodológicos construídos, pelo autor, possui um papel de destaque na solução deste problema. Entretanto resta uma indagação, a saber: qual o papel que a ética ou a moral possui para resolver este problema?

Seguindo este fio condutor, torna-se necessário estabelecer os limites entre a ética e a legislação. Este assunto constitui o principal tema deste trabalho. Ele será analisado no próximo capítulo com o auxílio do instrumental metodológico do capítulo segundo, bem como tendo em vista toda a problemática que envolve o princípio de utilidade, a ser apresentada neste capítulo.

A explicação mais detalhada do princípio de utilidade, bem como a colocação de alguns pontos de suas controvérsias, fornecendo possíveis interpretações e soluções constituem importante tarefa para que a delimitação entre a ética e a legislação seja efetuada. Isto ocorre 
porque toda a solução deste problema, a ser exposto no capítulo quarto, será fornecida com base no princípio de utilidade.

Tendo em vista a importância de entender-se, de maneira mais detalhada, o princípio de utilidade, para a compreensão do estabelecimento dos limites entre a ética e a legislação, parte-se para o desenvolvimento deste capítulo. 


\subsection{O princípio da utilidade de Jeremy Bentham}

Conforme mencionado no segundo capítulo do presente trabalho, Bentham constrói um modelo de indivíduo, cujas ações são guiadas pelos sentimentos de prazer e dor. Foi exposto que ambos os sentimentos são responsáveis: a) pela norma que distingue o que é certo do que é errado e b) pela cadeia de causas e efeitos de uma ação ${ }^{77}$.

Isto não quer dizer que prazer seja definido como bem, pois, tendo em vista a teoria lógica e da linguagem de Bentham, isto seria cometer uma falácia naturalista ${ }^{78}$. Ou seja, um termo moral (ficcional) como bem não pode ser definido por um termo real como prazer, pois, a noção de definição para Bentham requer que certas condições sejam preenchidas. Entre elas, fundamentalmente, consta a condição de que os termos pertençam ao mesmo nível de análise. Não podemos misturar por meio de definições dois níveis diferentes como aqueles dos termos ficcionais e reais.

Neste contexto, prazer não pode ser definido como preferência, vontade, escolha ou bem, uma vez que estes são termos ficcionais, enquanto que prazer é uma sensação, um termo real, ou seja, a noção de prazer não pode ser separada da noção de sensação. No entanto, pode-se relacionar os dois níveis, real e ficcional, fazendo uso do método de paráfrase introduzido por Bentham e mencionado no capítulo segundo deste trabalho. Da utilização deste método emerge a idéia de que um critério fundamental de construção do corpo teórico é o de que estamos autorizados a fazer uso de termos ficcionais apenas e tão somente na medida em que eles

\footnotetext{
${ }^{77}$ Loc. Cit.

${ }^{78}$ Uma falácia naturalista constitui a tentativa de naturalizar certos termos que não são naturais. Ou definir um termo natural em termos de outro não natural. Em suma, representa, em todos os casos, um argumento que induz ao erro.
} 
mantenham uma relação metodológica de dependência com os termos reais. Tendo em vista este método de explicação, prazer pode ser interpretado (mas não definido) nos termos acima, desde que não seja separado da noção de sensação ${ }^{79}$.

Bentham considera que prazer é o único fim da ação e pode ser também motivo dela. A partir disto e utilizando-se do método de paráfrase do autor, é possível construir uma relação metodológica entre o termo ficcional interesse e o termo real prazer. Estas relações, conforme mencionado, são critérios para adoção dos termos ficcionais no corpo teórico e decorrem do método de construção do autor ${ }^{80}$. Por exemplo: é possível elaborar uma relação entre este termo real, prazer, e o termo ficcional, interesse, pois pode-se considerar que aumentos na quantidade do primeiro geram incrementos na quantidade do segundo. O contrário também ocorre.

Do mesmo modo, é possível interpretar vontade, interesse e querer em termos de prazer, uma vez que um aumento em algumas dessas características deve gerar incrementos no prazer ou no bem. Este seria um exame possível da relação entre os termos reais e ficcionais. A partir dela, o termo prazer (real) seria definido em termos de sensação ou manteria seu significado ligado ao de sensação (termo também real), podendo ser interpretado, mas nunca definido em termos ficcionais.

Assim, entendido que a relação entre termos reais e ficcionais é metodológica e não lógica, é possível afirmar que Bentham não está cometendo uma falácia naturalista, ao dizer que

\footnotetext{
${ }^{79}$ Sobre isito cito Goldwoth em Bentham's Concept of Pleasure: Its Relation to Fictiticious Terms p. 11: “(...) Appearances to the contrary not withstanding, whenever Bentham asserts or express the view that good is pleasure or that good is the maximum surplus of pleasure over pain, he is not providing definitions but paraphrases of the term good. Given Bentham's characterizations, paraphrases itself could be viewed as a kind of definitional analysis, in which real terms serve as equivalences for fictitious terms, were it not for Bentham's explicit claims that such equivalences are not possible. Thus identifying the relation between real and fictitious terms as supervenience provides us with the key to understanding what Bentham meant by paraphrases (...)".

${ }^{80}$ A respeito disto cito Goldworth em Bentham's Concept of Pleasure: Its Relation to Fictiticious Terms p. 8: “(...) This description of paraphrasis appears to allow for the elimination for the fictiticious part of language by a reduction to the real part (...)".
} 
bem $^{81}$ (termo ficcional) é prazer (termo real), pois não pretende definir (no sentido tradicional) bem em termos de prazer e, portanto, não reduz propriedades morais (ficcionais) a propriedades descritivas reais. O que o autor faz é estabelecer uma conexão metododológica do tipo paráfrase entre bem e prazer, ainda que em alguns momentos isto não seja explicitado.

Desta forma, tendo em vista a relação do sentimento de prazer (termo real) com a noção de bem (termo moral ficcional) o autor descreve o princípio da utilidade como um princípio que reconhece a sujeição das ações dos indivíduos às sensações de prazer e dor. O objetivo de Bentham é colocar prazer e dor como fundamento da ação individual e coletiva para que os interesses sejam revelados da forma mais clara possível. É necessário notar que os interesses sociais se reduzem à soma dos interesses individuais (referente à noção de comunidade do autor).

O princípio da utilidade é citado em uma série de obras suas, mas é em "Uma introdução aos princípios da moral e da legislação" que ele aparece da forma mais clara, conforme já enunciado:

\section{“[...] Por principio da utilidade entende-se aquele princípio que} aprova ou desaprova qualquer ação, segundo a tendência que tem a aumentar ou a diminuir a felicidade da pessoa $^{82}$ cujo interesse está em jogo, ou, o que é a mesma coisa em outros

\footnotetext{
${ }^{81}$ A respeito disto cito Bentham em An Introduction to the Principles of Moral and Legislation p. 48: “[...] Now, pleasure is in itself a good [...]".

${ }^{82}$ Conforme mencionado no capítulo segundo, a primeira formulação de princípio de utilidade talvez possua uma tradução equivocada do termo party, pois é traduzido como pessoa, quando em inglês este termo pode ter um significado coletivo. A tradução sugerida aqui seria parte, pois esta palavra poderia dar tanto um significado coletivo quanto singular. A passagem em inglês presente nos Princípios da Moral e da Legislação é a seguinte: “[...] By the principle of utility is meant that principle which approves or disapproves of every action whatsoever. according to the tendency it appears to have to augment or diminish the happiness of the party whose interest is in question: or, what is the same thing in other words to promote or to oppose that happiness. I say of every action whatsoever, and therefore not only of every action of a private individual, but of every measure of government [(...]”. A segunda definição em inglês é a seguinte: “(...) To this denomination has of late been added, or substituted, the greatest happiness or greatest felicity principle: this for shortness, instead of saying at length that principle which states the greatest happiness of all those whose interest is in question, as being the right and proper, and only right and proper and universally desirable, end of human action: of human action in every situation, and in particular in that of a functionary or set of functionaries exercising the powers of Government [...]".
} 
termos, segundo a tendência a promover ou a comprometer a referida felicidade. Digo qualquer ação, com o que tenciono dizer que isto vale não somente para qualquer ação de um indivíduo particular, mas também de qualquer ato ou medida de governo $[. .$.$] '. Ou, em outros termos, o princípio da utilidade é$ definido da seguinte forma: "[...] O princípio que estabelece a maior felicidade de todos aqueles cujo interesse está em jogo, como sendo a justa e adequada finalidade da ação humana, e até a única finalidade justa, adequada e universalmente desejável: da ação humana, digo, em qualquer situação ou estado de vida, sobretudo na condição de um funcionário ou grupo de funcionários que exercem os poderes do governo [...]'.(Bentham, 1789, p.10).

Tendo em vista ambas as definições do princípio da utilidade de Bentham, importantes questões podem ser levantadas: de acordo com o princípio de utilidade, o indivíduo ao agir, deve levar em conta os seus próprios interesses ou o interesse de todos os indivíduos afetados por sua ação? este é um princípio que serve como guia de ação individual ou como guia de ação coletiva? Ou ainda, se ambas interpretações (individual e coletiva) são contempladas, qual a relação entre elas?

Tais questões são controversas tanto dentro da obra de Bentham quanto fora dela. No entanto, de acordo com a tese ontológica mencionada no segundo capítulo, a interpretação adequada à primeira formulação do princípio de utilidade, explicitada por Bentham, é aquela em que o agente relevante é o indivíduo. Portanto, a utilidade constitui um princípio que serve, fundamentalmente, como guia de ação individual em que o indivíduo possui como propriedade principal uma racionalidade auto-interessada capaz de efetuar cálculos intertemporais. 
Entretanto, a segunda formulação do princípio de utilidade, acima mencionada, poderia nos remeter a uma interpretação contrária à primeira formulação do princípio. Esta segunda explicitação do princípio tende a dar ênfase não mais ao comportamento autointeressado do indivíduo, mas a uma possível conduta não auto-interessada por parte deste agente. Ainda que seja possível empreender esforço para tentar subsidiar esta interpretação é minha posição que a explicação que torna mais coerente o pensamento de Bentham, sobre este assunto, é aquela do indivíduo auto-interessado.

Do mesmo modo, ainda que as definições do princípio de utilidade possam levar a duas interpretações conflitantes, a saber: por um lado, a consideração da ação individual e, por outro, a importância da ação coletiva, a posição deste trabalho, decorrente da tese ontológica, é a de que a ação relevante é a ação individual, e, portanto, a ação coletiva será sempre interpretada como constituída da agregação das ações individuais. É importante notar que a noção de agregação do autor é entendia como uma soma e não outro tipo de agregação.

Ou seja, a interpretação do presente trabalho, no que concerne a este tema, considera que o princípio da utilidade de Bentham é, em todos os casos, um guia de ação individual. A ação coletiva só pode ser entendida como soma das ações dos indivíduos. Esta relação de agregação que a ação coletiva mantém com a ação individual é denominada tese reducionista. Com esta explicação, deve-se aplicar o principio da utilidade tanto para orientar ações individuais quanto para orientar e avaliar ações que envolvem mais de um indivíduo, dependendo do referencial. Contudo, ressalta-se que a principal ação na qual o autor está interessado em construir um corpo teórico para avaliar refere-se à ação coletiva. A ação individual aparece para construir uma concepção consistente de teoria da ação coletiva.

Resumidamente, para Bentham, o indivíduo é a unidade ontológica que possui existência na realidade e é guiado pelos sentimentos de dor e prazer. O princípio da utilidade 
reconhece a sujeição do gênero humano a estas também denominadas entidades reais (prazer e dor). Considerando este reconhecimento por parte do princípio da utilidade, pode-se dizer que estes sentimentos constituirão o que realmente será importante do ponto de vista da utilidade.

Assim, o princípio da utilidade servirá de guia para analisar tendências boas ou más das ações, de acordo com prazeres e dores envolvidos (isto dependerá do número de indivíduos afetados pela ação dado que toda ação coletiva nada mais é do a soma das ações individuais). Caso existisse um espectador imparcial ${ }^{83}$, que utilizasse o princípio de utilidade como guia para julgar uma ação, poder-se-ia dizer que ele contaria todos prazeres e dores que estivessem em jogo, a fim de avaliar a tendência geral do ato. Ou seja, ele levaria em conta todos os prazeres e dores dos indivíduos afetados pela ação.

Neste sentido, o princípio da utilidade é um princípio que serve de guia para ação coletiva. Em outras palavras, sob a ótica de quem julga uma ação e não é afetado por ela nem possui nenhum interesse particular contrário à aplicação do princípio da utilidade, todas as pessoas cujos interesses estão em jogo serão levadas em conta.

Porém, como esta coletividade é entendida como a soma de indivíduos ${ }^{84}$ de uma comunidade, pode-se dizer que em sua raiz, este princípio constitui um princípio de ação individual. Ou seja, é o indivíduo que possui existência ontológica e é a partir dele que se deve realizar o cômputo de prazeres e dores para avaliação de uma ação, de acordo com o princípio de utilidade.

\footnotetext{
${ }^{83} \mathrm{O}$ papel de espectador imparcial deveria ser adotado pelos homens do governo, pois a estes cabe zelar pela maior felicidade possível da comunidade.

${ }^{84}$ É importante notar que uma hipótese subjacente à idéia da comunidade entendida como soma de indivíduos referese ao fato de que os indivíduos são independentes uns dos outros. Esta questão constituirá, para os utilitaristas contemporâneos, uma das maiores dificuldades dos conceitos de Bentham. Não obstante, poder-se-ia argumentar que a idéia da comunidade como soma representaria apenas uma aproximação da noção de comunidade.
} 
Do ponto de vista do indivíduo que age, este levará em consideração aquilo que lhe é prazeroso, segundo o princípio da utilidade, e nada pode obrigar-lhe a levar em conta outros interesses. Em outros termos, o princípio de utilidade não obriga o indivíduo a agir de acordo com interesses alheios ou a atuar de forma contrária a seus próprios interesses ${ }^{85}$. Reitera-se aqui a predominância do pressuposto do auto-interesse como propriedade fundamental do indivíduo.

Contudo, diz Bentham, nada impede que este mesmo indivíduo considere interesses de outros indivíduos, como, até mesmo, fazendo parte de seus próprios interesses. Ou seja, age mais de acordo com o princípio da utilidade aquele que incluir dentro de seus próprios interesses, interesses de outros membros da comunidade. Aquele que ao agir, obtiver prazer em não causar desprazer a outros ou até mesmo auferir prazer em causar benefício, respeita mais o princípio da utilidade, pois gera maior quantidade de prazer no cômputo geral. Para que isto ocorra basta que indivíduos cultivem motivos sociais ou semi-sociais, ainda que mantenham suas características auto-interessadas.

Assim, sob a ótica do agente, o princípio da utilidade constitui um guia de ação individual, uma vez que a ação deve ser efetuada de acordo com o interesse de quem age, embora isto não exclua levar em consideração interesses alheios.

Tendo em vista ambas a dimensões em que o princípio da utilidade pode ser enxergado (individual e coletiva), é possível dizer que tal princípio é individual na medida em que o indivíduo o utiliza como guia para agir, de acordo com seus interesses, e coletivo (sempre de acordo com a tese reducionista) na medida em que um expectador imparcial (no caso o

\footnotetext{
${ }^{85}$ Sobre isto cito Bentham em An Introduction to the Principles of Morals and Legislations p.143: "[...] What motives (independent of such legislation and religion may chance to furnish) can one man have to consult the happiness of another? By what motives, or (which comes to the same thing) by what obligations, can be bound to obey the dictates of probity and beneficence? In answer to this, it cannot but be admitted, that the only interests which a man at all times and upon all occasions is sure to find adequate motives for consulting, are his own. Notwithstanding this, there are no occasions in which a man has not some motives for consulting the happiness of other men. In the first place, he has in all occasions, the purely social motive of sympathy or benevolence: in the next place, he has, on most occasions, the semi-social motives of love of amity and love of reputation [...]”.
} 
governo) o utiliza para verificar a tendência (boa ou má) de uma ação, considerando todos os prazeres e dores dos indivíduos afetados pelo ato em questão ${ }^{86}$.

Conforme mencionado acima, este expectador imparcial deve ser o governo, quando estiver preocupado em resguardar os interesses da coletividade (interpretada como soma), conforme enuncia o princípio da utilidade, e não apenas seus próprios interesses (interesses sinistros).

${ }^{86} \mathrm{O}$ balanço de prazeres e dores envolve mais do que simplesmente somar prazeres e dores e diminuí-los uns dos outros. Conforme mencionado no capítulo segundo da presente dissertação, este balanço envolve o valor dos prazeres como intensidade, proximidade, longinquidade, etc. 


\subsection{Algumas interpretaç̃̃es do princípio de utilidade de Bentham: Uma possível solução para o problema da minoria}

Um problema levantado por muitos comentadores de Bentham, refere-se à sua consideração do principio da utilidade na aplicação para a ação coletiva como uma agregação das ações individuais e seu método de operacionalização do princípio da agregação visto como soma de interesses individuais. Tal método tem sido criticado como um dos maiores problemas de sua obra. O método para avaliar a tendência boa ou má de um ato, de acordo com o princípio da utilidade, conforme mencionado no capítulo segundo deste trabalho, consiste no seguinte:

Para um indivíduo considerado em si mesmo, o valor de um prazer ou uma dor será maior ou menor segundo as quatro circunstâncias ou propriedades: 1) Intensidade, 2) Duração, 3) Certeza ou incerteza e 4) Proximidade ou longinquidade. Com relação à tendência geral do ato, leva-se em conta três outras circunstâncias ou propriedades, a saber: 5) Fecundidade (probabilidade que o prazer ou a dor tem de serem seguidos por sensações de mesma espécie) e 6) Pureza (probabilidade que o prazer e a dor têm de não serem seguidos por sensações contrárias $)^{87}$ e 7 ) extensão $\left(n^{\circ}\right.$ de pessoas as quais se estende o respectivo prazer ou dor ${ }^{88}$. Portanto, o valor do prazer e da dor será maior ou menor conforme estas sete circunstâncias enumeradas. Levados em conta os valores de prazer e dor, bem como a extensão ou números de pessoas afetadas pela ação procede-se ao balanço descrito no capítulo segundo deste trabalho.

A este método de soma várias críticas são efetuadas. A primeira delas refere-se à tese reducionista, do autor, sobre a noção de comunidade como soma de indivíduos. Vários

\footnotetext{
${ }^{87}$ Ambas as circunstâncias não são propriedades do prazer ou da dor. Portanto, só devem ser consideradas na avaliação da tendência do ato.

${ }^{88}$ Note-se que a soma dos prazeres e dores de indivíduos só é possível porque os prazeres sentidos por cada um são iguais, diferindo apenas com relação às seis circunstâncias mencionadas .
} 
críticos do utilitarismo e até mesmo alguns utilitaristas argumentam que a sociedade não pode ser entendida como soma de indivíduos, pois isto envolveria desconsiderar que os indivíduos interagem. Uma outra dificuldade inerente ao método de soma de prazeres, descrito acima, decorre do fato de que a maximização da utilidade levaria à supressão dos interesses da minoria em prol dos interesses da maioria, uma vez que o maior número de pessoas seria beneficiado em detrimento do menor número, ainda que o sofrimento imposto à minoria seja superior ao prazer auferido pela maioria.

Sobre esta segunda crítica ao método de soma dos prazeres, alguns estudiosos do assunto, como Ayer $^{89}$, defendem que aquilo que o autor pretendia era colocar em sua idéia de utilidade a maior quantidade de prazer ou felicidade possível, não importando a sua distribuição entre o número de pessoas. Ou seja, sua frase: "the greatest happiness of the greatest number", apenas revelaria a grande importância do número de pessoas no cômputo geral do total de prazeres. Este comentador sustenta que a distribuição de prazeres para um número de pessoas, não representa um conceito adicional dentro do conceito de utilidade de Bentham. A distribuição de prazer resultante de uma ação não seria um conceito distinto da quantidade de prazer auferida. O presente trabalho concorda com esta interpretação.

Bentham adotou, pela primeira vez, a concepção de utilidade como sendo idêntica à expressão "the greatest happiness of the greatest number", mas ao final de sua vida, ele teria reformulado este conceito para apenas "the greatest happiness". De acordo com ele, existe uma grande dificuldade na interpretação da primeira formulação do princípio, pois: como comparar o

\footnotetext{
${ }^{89}$ No que concerne a isto cito Burne em Bentham and The Utilitarian Principle p. 2: " [...] In this essay professor Ayer says that he is fairly sure that Bentham held a right action is one which produces the greatest measure of happiness, no matter how it is distributed, and that when he spoke of "the greatest happiness of the greatest number he intended only to emphasize that one of the most important factors determining the total quantity of happiness is the number o persons affected. The distribution of the happiness resulting for an action, as distinct from its quantity, was not, Professor Ayer suggests intended by Bentham to be an independent criterion of the rightness of an action $[\ldots] "$.
} 
número de pessoas com a quantidade de felicidade? Pode ocorrer que a maior quantidade de prazer ou dor refira-se à minoria e não à maioria, em determinada circunstância.

Bentham ilustra esta dificuldade no seguinte exemplo:

“[...] Prenez une société quelconque: divisez-la en deux parties inégales : appelez l'une majorité, l'autre minorité. Déduisez du total les sentiments de la minorité : ne faites entrer en compte d'autres sentiments que ceux de la majorité. - Vous trouverez pour résultat de l'opération une balance, non de profit, mais de perte sur la somme du bonheur total. La vérité de cette proposition sera d'autant plus palpable, que le nombre de la minorité se rapprochera plus de celui de la majorité : en d'autres termes, que moindre sera la différence entre les deux parties inégales: et en supposant les deux parties égales, la quantité d'erreur sera alors à son maximum.

Soit le nombre de la majorité 2,001, le nombre de la minorité 2,000 : soit, d'abord, la masse de bonheur divisée de telle sorte, que chacun des 4,001 en possède une portion égale. Prenez alors à chacun des 2,000 sa part de bonheur, et partagez-la de manière ou d'autre entre les 2,001: au lieu d'une augmentation de bonheur, grande sera la diminution que vous obtiendrez pour résultat. Soient, pour rendre la proposition plus complète, les sentiments de la minorité mis entièrement hors de compte, il se peut que le vide ainsi laissé, au lieu de rester à l'état de vide, se remplisse de malheur, de souffrance positive qui, en grandeur, en intensité et en durée réunies, soit porté au plus haut point qu'il soit au pouvoir de la nature humaine d'endurer.

Otez aux 2,000, et donnez à vos 2,00l tout le bonheur que vous trouvez en la possession des 2,000 : remplacez le bonheur que vous avez pris par toute la quantité de malheur que le récipient peut contenir. Le résultat sera-t-il un profit net ajouté à la somme totale 
de bonheur possédée par les 4,001 réunis? Tout au contraire. Le profit fera place à la perte. Comment? parce que telle est la nature du récipient, que dans un espace de temps donné il peut contenir une plus grande quantité de malheur que de bonheur.

A l'origine, placez vos 4,001 dans un état de parfaite égalité, sous le rapport des moyens, ou des instruments de bonheur, et spécialement du pouvoir et des richesses: chacun d'eux dans un état d'égale liberté : chacun possédant une égale portion d'argent ou d'objets précieux : c'est dans cet état que vous les trouverez. Prenant alors vos 2,000, réduisez-les en esclavage, et, n'importe dans quelle proportion, partagez-les avec ce qui leur appartient entre vos 2,001. L'opération terminée, quel est le nombre de ceux qui auront obtenu pour résultat une augmentation de bonheur? La question se résout d'elle-même.

S'il en était autrement, remarquez l'application pratique qu'il faudrait en faire aux îles Britanniques. Dans la Grande-Bretagne, prenez tous les catholiques, faites-en des esclaves, et partagez-les dans une proportion quelconque, eux et leur famille, entre le corps entier des protestants. En Irlande, prenez tous les protestants, et partagez-les de la même manière entre tout le corps des catholiques “[...]. (Bentham, 1834, Déontologie, ou Science de la Morale).

As questões que podem ser levantadas a partir do exemplo acima são as seguintes: Devemos escolher entre a quantidade de pessoas ou a quantidade de felicidade ${ }^{90}$ ? Deve-se privilegiar a maioria, em detrimento do imenso sofrimento de uma minoria? A resposta a esta

\footnotetext{
${ }^{90}$ A quantidade de felicidade maior em uma sociedade não necessariamente coincide com a sua distribuição entre o maior número de pessoas, pois um prazer de pequena duração e intensidade gerado na maioria pode ser menor do que uma dor muito intensa e duradoura causada em uma minoria.
} 
pergunta é negativa pois, tanto o comentador Ayer ${ }^{91}$, quanto este trabalho concordam com a idéia de que é necessário privilegiar a contagem total de felicidade, levando em conta todos os elementos necessários para mensurar o exato valor dos prazeres, a saber: intensidade, duração, certeza ou incerteza, proximidade ou longinquidade, fecundidade, pureza e extensão $\left(\mathrm{n}^{\circ}\right.$ de pessoas as quais se estende o respectivo prazer ou dor). Ou seja, Bentham teria construído um método de contagem de prazeres e dores que privilegia, também, outros elementos além do número de indivíduos no cômputo geral do balanço.

Desta forma, o número de pessoas (extensão) apenas representaria um elemento adicional (ainda que fundamental), assim como a intensidade, duração, certeza ou incerteza, proximidade ou longinquidade, fecundidade e pureza, para realizar o cômputo geral dos prazeres e dores. Levar em consideração a extensão do número de pessoas afetadas por uma ação não quer dizer que os interesses da minoria devam ser negligenciados, principalmente nas circunstâncias em que possuem maior peso no cômputo geral do balanço entre prazeres e dores, quando comparados aos interesses da maioria ${ }^{92}$.

Em outros termos, elementos importantes que caracterizam o cômputo dos prazeres e dores, como intensidade e duração, podem fazer com que a minoria, em determinadas circunstâncias, tenha um peso superior ao peso dos prazeres e dores que é atribuído à maioria.

Assim, a reformulação de seu conceito inicial de utilidade "the greatest happiness of the greatest number" para "the greatest happiness" justifica-se, pois desta forma a felicidade da minoria não seria desprezada. Ou seja, o princípio da utilidade pode ser interpretado sob uma ótica que contempla o problema da minoria

\footnotetext{
${ }^{91}$ É importante atentar para o fato de que não tive acesso ao acesso às idéias de Ayer a partir de seus escritos, mas sim através dos escritos de Burne

${ }^{92}$ Isto ocorreria, especialmente, nos casos em que uma maioria de número próximo à minoria cause um imenso sofrimento a esta minoria, conforme ilustrado no exemplo dado pelo autor.
} 
Disto, é possível concluir que apesar da maioria expressar da forma mais eficiente os interesses gerais, é necessário considerar, além da quantidade de pessoas, todos os outros instrumentos de cálculo de valores de prazeres e dores (como intensidade e proximidade), quando considera-se a tendência geral de um ato. 


\subsection{Princípio da Utilidade e a Interação entre indivíduos: Benevolência convergente com o princípio da utilidade.}

Neste tópico buscar-se-á afastar a idéia de egoísmo do princípio de utilidade. Tenciona-se mostrar que este princípio converge para a benevolência e não para o egoísmo. Esta seção refere-se a mais um esclarecimento quanto a possíveis interpretações do princípio de utilidade.

Conforme mencionado no capítulo segundo referente à reconstrução racional do autor, os motivos de ações não podem ser ditos bons ou maus em si mesmos. Somente a dor e o prazer são maus ou bons em $\mathrm{si}^{93}$. Se, em um certo sentido, os motivos são ditos bons ou maus o são, exclusivamente, com respeito à tendência que têm a produzir prazer ou dor, em determinada circunstância. Em outras palavras, um mesmo motivo, dependendo da circunstância e do indivíduo que age, pode originar atos bons (que proporcionam prazer) ou maus (que propiciam desprazer).

De acordo com Bentham, a benevolência deve ser entendida como motivo em bom sentido, derivado dos prazeres da simpatia. Este, segundo o autor, é o motivo social mais importante na tendência que possui a harmonizar os interesses de um indivíduo com os da comunidade (entendida como soma de indivíduos).

O motivo da benevolência é aquele cujos ditames apresentam a maior certeza de coincidir com o princípio da utilidade, pois o significado deste motivo enuncia que se um ato gerar prazer para o indivíduo que o pratica, certamente não ocasionará dor para aquele que é

\footnotetext{
${ }^{93}$ Cabe lembrar que prazer não é definido em termos de bem, mas sim mantém uma relação com bem, uma vez que incrementos de bem em um indivíduo se traduzem em aumentos de prazer.
} 
afetado por ele. Ou seja, o motivo da benevolência seria aquele que preza pela maior tendência a gerar felicidade no cômputo geral do balanço entre prazer e dor dos indivíduos afetados por uma ação. Assim, é possível concluir, explicitamente, que os ditames da utilidade não são nem mais nem menos que os ditames da benevolência ${ }^{94}$.

Ao contrário do que se poderia pensar, o princípio da utilidade não se reduz ao egoísmo, uma vez que é responsável por estabelecer uma regra que, coletivamente, sempre leva em conta todos os indivíduos afetados por uma ação, visando garantir a maior felicidade possível dentro de uma comunidade. Em outras palavras, o princípio de utilidade é condizente com os ditames da benevolência, pois zela, assim como este motivo da ação, pelo bem-estar dos indivíduos pertencentes a uma sociedade.

Tendo claro estas considerações iniciais referentes ao motivo de ação denominado benevolência e sua coincidência com o princípio de utilidade, parte-se para sua distinção em relação à beneficência e a importância de sua aplicação em uma comunidade.

A benevolência se divide em duas correntes: uma positiva, ou que diz respeito a gerar prazer aos outros e outra negativa, ou em outros termos, que se abstém de causar dor a outrem $^{95}$ (é o mesmo que probidade). O motivo denominado benevolência implica na disposição de realizar atos beneficentes.

Atos beneficentes podem, contudo, ser praticados sem que exista a disposição para tal. Ou seja, atos beneficentes podem vir desacompanhados de benevolência. O contrário também pode ocorrer, pois um indivíduo pode possuir a disposição benevolente sem traduzi-la

\footnotetext{
${ }^{94}$ Sobre isto cito Bentham em An Introduction to the Principles of Morals and Legislation p.56: "[...] Of all these sorts of motives, good-will is that of which the dictates, taken in a general view, are surest of coinciding with those of the principle of utility. For the dictates of utility are neither more nor less than the dictates of the most extensive and enlightened (that is well-advised) benevolence [...]".

${ }^{95}$ A respeito disto cito Bentham em Déontologie ou Science de la Morale p.98: "[...] Nous avons parlé de la bienveillance effective comme se divisant en deux branches, l'une, positive, ou qui confère des plaisirs à autrui, et l'autre, négative, ou qui s'abstient de leur infliger des peines [...]".
} 
em beneficência, no caso em que a benevolência não se manifesta em atos. A disposição benevolente transformada em atos é chamada benevolência efetiva.

Aos olhos do sentimentalista, a benevolência, acompanhada ou não da beneficência, deve receber a maior parte de aprovação pública. Contudo, para Bentham, a benevolência que não carrega os frutos da beneficência (as ações propriamente ditas) não passa de uma árvore infrutífera. Segundo o autor, somente a benevolência que resulta em atos de beneficência possui valor. Para Bentham, a benevolência isolada é apenas uma sombra de virtude, uma vez que só se torna efetiva, quando se manifesta em atos ${ }^{96}$. Aqui reitera-se a importância de avaliar ações a partir das conseqüências que causam. Ainda que a intenção possua um papel importante na avaliação de crimes, ela apenas será considerada como tendo relevância quando for relacionada, diretamente, às conseqüências das ações.

O campo negativo da benevolência efetiva compreende a ação, ou melhor, a negação de uma ação pela qual evitamos afetar outros dolorosamente. O campo positivo da benevolência efetiva consiste em efetuar atos que geram prazer a outros. Esta última área da benevolência (positiva), segundo Bentham, é muito menos considerável que a forma negativa, pois os meios que possuímos para entender a felicidade do outro são muito mais restritos do que o poder que temos de lhes fazer mal. Praticamente, não há um só homem que não tenha o poder de fazer mal ou causar dor (sob uma forma qualquer) a quase todos que estão ao seu redor. Porém o mesmo não ocorre com a possibilidade de causar prazer ou felicidade a outro.

A parte negativa da benevolência efetiva consiste em abster-se de agir. Tal abstinência evita uma pena ou cria um prazer. Esta área da benevolência pressupõe o poder de atenuar um sofrimento ou de conferir um prazer, sendo destinada a impedir os efeitos de uma

\footnotetext{
${ }^{96}$ A respeito disto cito Bentham em Déontologie ou Science de la Morale p.99: "[...] La bienveillance effective se manifeste par des actes : elle suppose un bien capable d'augmentation, ou un mal susceptible d'éloignement ou de diminution [...]".
} 
disposição que se deixássemos agir aumentaria a soma do mal ou diminuiria a soma de felicidade.

Assim, a benevolência pressupõe o aumento do bem ou o abrandamento do mal, sendo que a influência que um homem exerce dentro de uma sociedade, seja ela por meio de vícios (disposição que possui para gerar dor) ou virtudes (disposição para ocasionar prazeres) aumenta conforme a elevação social do indivíduo e a sua inteligência para fazer o mal ou o bem. Por exemplo: alguns reis, como Henrique $\mathrm{IV}^{97}$ e Charles XII, a partir de interesses totalmente egoístas e devido à posição social que ocupavam, ao invés de seguirem os ditames da benevolência e, portanto, da utilidade, sacrificaram milhões de pessoas. Ou seja, pelo poder que possuem, estão mais aptos a praticar a benevolência, em larga escala, os governantes ${ }^{98}$.

Contudo, ainda que um indivíduo não possua poderes para salvaguardar os interesses de grandes somas de pessoas, sempre há bons motivos para que atos benevolentes sejam praticados. O egoísmo, assim, consistiria, precisamente, na recusa em praticar tais atos, representaria a rejeição do próprio princípio de utilidade.

Não obstante a importância da benevolência e beneficência para o bom convívio social, o bem resultante da benevolência efetiva é restrito, quando comparado àquele que os indivíduos produzem para si. Bentham ressalta que todos os bens que fazemos para os outros são pequenos quando comparados ao bem que fazemos em vista de nós mesmos. As afecções de simpatia não são e nem podem ser maiores do que as afecções pessoais. Portanto, aquilo que damos sem esperar nada em troca não pode ser comparado a aquilo que é doado em

\footnotetext{
${ }^{97}$ A respeito disto cito Bentham em Déontologie ou Science de la Morale p.99: "[...] L'influence qu'un homme exerce sur la société, par ses vices et ses vertus, s'étend en raison de son élévation sociale. La puissance du bien et celle du mal augmentent simultanément. Les amours d'Henri IV ont produit une masse incalculable de maux [...] '..

${ }^{98}$ Sobre isto cito Bentham em Déontologie ou Science de la Morale p.99: "[...] L'un et l'autre, dans un intérêt de jouissances égoïstes, quoique différentes, ont sacrifié des milliers d'hommes. Quand les lois de la morale seront comprises, quand la sanction populaire sera suffisamment éclairée, le monde ne sera plus victime des caprices des rois [...] ".
} 
retorno de outra coisa ${ }^{99}$. Por exemplo, as contribuições voluntárias, para o Estado, são bastante irrisórias quando comparado àquilo que o Estado arrecada por meio de requisições obrigatórias. Por meio destas considerações, reitera-se, novamente, a tese do presente trabalho, de que o indivíduo de Bentham é auto-interessado.

Entretanto, reitera-se que sempre é possível acrescentar às aspirações de prudência (cuidados individuais que não envolvem interações) e ao auto-interesse as leis de benevolência efetiva, no caso de interações entre agentes. Ou seja, é possível que a benevolência efetiva positiva e negativa ocupe junto com os cuidados pessoais o mesmo lugar dentro do domínio do dever ${ }^{100}$. Para isto, basta que os indivíduos compreendam que a sociedade só tem a ganhar quando a maximização de prazer é efetuada. Basta que entendam os reais ditames do princípio de utilidade, a saber: garantir o máximo de felicidade possível a uma determinada comunidade.

Para Bentham, é possível reformar o pensamento criador de palavras ou ações com tendências funestas que vão contra a benevolência efetiva ou em outros termos que negam o princípio da utilidade (maximização de prazer). A fim de dar eficácia a esta reforma, torna-se necessário remontar à origem dos motivos hostis à benevolência negativa. Abaixo apresentam-se algumas origens destes motivos contrários à benevolência:

1. Há um caso em que o interesse pessoal, simplesmente, se acha hostil em relação às simpatias beneficentes. Bentham ressalta que não há remédio contra esta atitude. Felizmente, estes casos são raros, pois não é freqüente que um mal qualquer ocorra, sem uma

\footnotetext{
${ }^{99}$ Sobre isto cito Bentham em Déontologie ou Science de la Morale p.98: “[...] Le bien produit par la bienveillance effective est restreint, comparé à celui que produisent les motifs personnels. Les affections sympathiques ne sont pas et ne peuvent pas être aussi fortes que les affections personnelle [...]".

${ }^{100}$ A respeito disto cito Bentham em Déontologie ou Science de la Morale p.99: "[...] On doit ajouter que, dans la plupart des cas, les inspirations de la prudence président aux lois de la bienveillance effective, et occupent avec elle, et d'un commun accord, la même place dans le domaine du devoir [...]".
} 
razão mais aparente. Além disso, dificilmente um homem odiará outro sem que também suscite ódio, pois, segundo o autor, todo ato, seja de benevolência, seja de malevolência, gera reações ${ }^{101}$.

2. O medo de preocupar-se com o próximo e a tranqüilidade ou preguiça constituem outras causas da ausência do princípio de benevolência negativa (abster-ser de agir, para não provocar dor). Ou seja, a acomodação pode ser uma causa contrária a aplicação da benevolência efetiva ${ }^{102}$.

3. Os sentimentos de orgulho e vaidade produzem o dogmatismo. Aqueles partidários do dogmatismo se atribuem uma superioridade que se reproduz por meio da palavra. Eles encontram a partir de qualquer ato que seja, motivo para reprimir, sem se preocupar com as conseqüências de seus atos. A benevolência ou o princípio da utilidade começaria indagando se a repressão pode ser de alguma forma útil, se no balanço dos prazeres e dores, este ato geraria mais prazer do que dor. A resposta claramente tenderia à dor. Contudo, este exercício não poderia ser feito por aqueles partidários do dogmatismo, pois, argumenta Bentham, orgulho e vaidade são sentimentos que impedem o recebimento de conselhos advindos da moral. Eles tendem a repelir tais conselhos.

Em outros termos, os sentimentos de orgulho e vaidade provocam, em todos os casos, o dogmatismo que não segue a benevolência ou o princípio de utilidade. Ao contrário, estes sentimentos são avessos ao princípio de utilidade, dado que geram mais dor do que prazer, por meio da repressão. Segundo o autor, conselhos dogmáticos são palavras que produzem dores

\footnotetext{
${ }^{101}$ Sobre isto cito Bentham em Déontologie ou Science de la Morale p.100: “(...) Toute voix, soit de bienveillance, soit de malveillance, a un écho : il y a une vibration qui répond à tout acte, soit en bien, soit en mal [...].

${ }^{102}$ A respeito disto cito Bentham em Déontologie ou Science de la Morale p.101: “(...) Ils n'ont aucun désir particulier de nuire: mais ils ne se dérangeront pas pour vous éviter un inconvénient. Ils aiment mieux dormir qu'agir. Ils énoncent une opinion hasardée, pour s'épargner la peine d'une recherch [...].
} 
sem compensação. Ou seja, as dores causadas pelas conseqüências do dogmatismo superam os prazeres produzidos por atos sustentados pelo orgulho e vaidade ${ }^{103}$.

Porém, o que diz a benevolência sobre o fato de que, talvez, rebeldes queiram destruir este dogmatismo por seus meios (anárquicos)? A benevolência veta também este tipo de prática, pois comandar oposição sob o jugo da fé infundada em leis naturais imaginárias ou na revelação é se distanciar da liberdade ou se aproximar do fanatismo. Dentro da parte política, a contribuição dos atos de benevolência seria entendida a partir dos atos de heroísmo do patriota. Isto significa que permitir a resistência, por meio de reformas, quando resultar mais utilidade do que a dor causada pela submissão é o mesmo que prosseguir rumo à liberdade.

4. Os interesses do mal querer ou a antipatia são, também, casos contrários à benevolência efetiva. Estes tipos de interesses assumem formas múltiplas e necessitam cessar, pois causam mal-estar às duas partes envolvidas (àquele que tem antipatia por outro e àquele que é alvo da antipatia) ${ }^{104}$. Segundo Bentham, estes interesses são tão funestos que não é possível perceber a natureza má de sua origem. Algumas vezes é a própria rivalidade de opinião que faz nascer tais sentimentos. A decorrência, mais freqüente, da antipatia é a vingança de quem é alvo deste sentimento. Isto faz com que ambas as partes tenham um balanço de dor maior do que o prazer, uma vez que quem é afetado pelas conseqüências da antipatia sente mais dor do que prazer e aquele que é atingido pela vingança resultante dos ataques feitos devido à antipatia, também experimentará mais dor do que prazer.

\footnotetext{
${ }^{103}$ Sobre isto cito Bentham em Déontologie ou Science de la Morale p.101: “(...) Quelquefois ils donnent des avis inopportuns ou déplacés. La bienveillance leur aurait appris à s'en abstenir. Des conseils déplacés sont des paroles en pure perte, qui produisent sur la personne conseillée une peine sans compensation, peine beaucoup plus grande que le plaisir savouré par la vanité conseillère [...] .

${ }^{104}$ No que concerne a isto cito Bentham em Déontologie ou Science de la Morale p.101: “(...) Les intérêts du mauvais vouloir, ou l'antipathie. Ceux-là prennent des formes multipliées, et demandent un double frein : car ils sont funestes aux deux parties, et, de l'un comme de l'autre côté, laissent après eux un surplus de mal-être [...]..
} 
Assim, tendo em vista estes motivos contrários à benevolência efetiva negativa, conclui-se que, em todas as ocasiões, a fim de negar tais motivos, é necessária a abstenção da ação que causaria mal. O autor acredita na possibilidade de reformar estas causas de motivos contrários à benevolência, a partir dos ensinamentos da verdadeira sabedoria ${ }^{105}$ da arte de se conviver em sociedade. Em outras palavras, é necessário que seja compreendido pelos indivíduos que a verdadeira educação e sabedoria consiste em ajudar a promover a maximização de felicidade da sociedade em que vivem ${ }^{106}$.

A benevolência efetiva só será reconduzida ao império das leis deontológicas quando o maior bem, qual seja: a felicidade, tornar-se o ponto central ao qual se reportarão todos os atos dos indivíduos. Este será o momento, segundo Bentham, em que começará a idade de ouro da ciência moral ${ }^{107}$. Quando a influência da beneficência (ou em outros termos os ditames da utilidade) for sentida em todos os lugares, o poder de recompensas será inútil e em grande parte o poder de punições também. Nenhum prazer será desperdiçado, assim como nenhuma pena será imposta inutilmente. Porém, até agora, segundo Bentham, poucas ações benevolentes têm sido efetuadas de forma sistemática pelos membros de comunidades.

O fato da realidade dos eventos ser contraditória com os ditames da utilidade, contudo, não exclui o pensamento que o autor sustenta de que seja possível que os homens, em

\footnotetext{
${ }^{105}$ Sobre isto cito Bentham em Déontologie ou Science de la Morale p.102: “[...] Le savoir-vivre s'applique à toutes les occurrences ordinaires, et qui, prises séparément, paraissent peu importantes : il consiste à s'abstenir de ce qui peut faire de la peine à autrui [...].

${ }^{106}$ Sobre isto cito Bentham em Déontologie ou Science de la Morale p.103: “[...] La disposition à contribuer, par tous les moyens permis, à la satisfaction des autres, et à s'abstenir de tout ce qui peut leur déplaire, c'est ce qui constitue la véritable politesse et le vrai savoir-vivre [...]".

${ }^{107}$ No que concerne a isto cito Bentham em Déontologie ou Science de la Morale p.100: "[...] Quand la bienveillance effective sera ramenée sous l'empire des lois déontologiques, quand le plus grand bien, le bonheur le plus universel, deviendront le point central auquel se rapporteront tous les actes, c'est alors que commencera l'âge d'or de la science morale. Quand son influence sera partout sentie, sa présence universelle, la puissance des récompenses rendra inutile, en grande partie, la puissance des châtiments [...] .
} 
algum momento, tendam mais a sustentar motivos sociais como causas de suas ações do que motivos dissociais.

O autor ressalta que a disposição para contribuir, por todos os meios permitidos, à satisfação dos outros e a abstenção de tudo que possa causar desprazer é o que constitui a verdadeira polidez e o verdadeiro saber viver ${ }^{108}$. Ou seja, a benevolência seja ela positiva ou negativa deve ser cultivada e estimulada, permanentemente, entre os membros de uma comunidade, pois seus ditames coincidem com a maior geração de prazer possível.

Desta forma, conclui-se que o princípio de utilidade, quando aplicado à coletividade, concorda, inteiramente, com aquilo que prescreve a benevolência efetiva, pois quanto mais os indivíduos gerarem, espontaneamente, prazer ou se absterem de ocasionar dor a outros, maior será o montante de felicidade gerado no cômputo do balanço de prazer e dor do somatório de indivíduos.

108 Sobre isto cito Bentham em Déontologie ou Science de la Morale p.103: “(...) La disposition à contribuer, par tous les moyens permis, à la satisfaction des autres, et à s'abstenir de tout ce qui peut leur déplaire, c'est ce qui constitue la véritable politesse et le vrai savoir-vivre [...] . 


\subsection{O Princípio da Utilidade como recurso para a construção de um meio-termo entre o Conservadorismo e a Anarquia: Construção de uma forma de Governo} ou Estado

Depois de apresentadas as primeiras seções do capítulo, que se referem às explicações e interpretações possíveis do princípio de utilidade, apresenta-se a contextualização em que este princípio surge. Tenciona-se verificar qual o debate metametodológico que a elaboração deste princípio vem a responder.

Bentham escreveu sobre quase todos os assuntos em que o princípio da utilidade é aplicável ${ }^{109}$. Em grande parte destes escritos, o autor critica a proteção injustificada de muitas leis e instituições sociais e o excessivo prolongamento de sua duração. Bentham ressalta as péssimas conseqüências de tal prática para a humanidade, como a criação de mitos e mal-entendidos (dogmáticos) que, em sua concepção, deveriam ser desvendados por teóricos antes que os censores decidissem agir.

O autor escreveu sobre lógica e lingüística ${ }^{110}$ com a finalidade de aplicação direta ao argumento político, bem como para apresentar qual seria o papel dos legisladores ${ }^{111}$. O intuito de Bentham era o de impedir que os legisladores escondessem, por meio da obscuridade da linguagem, injustiças e deformidades que a lei pudesse apresentar. Bentham não queria que a

\footnotetext{
${ }^{109}$ Sobre isto cito Hart em Essays on Bentham p.1: “[...] He wrote on almost every conceivable subject to which the application of utilitarian principles can make a difference and on many subjects to which those principles might at first seem totally irrelevant [...]".

${ }^{110}$ A teoria da linguagem de Bentham é vista, neste trabalho, como um recurso metodológico para operacionalizar sua epistemologia.

${ }^{111}$ A respeito disto cito Bentham em Essays on Logic, 221: " [...] Of the art or science of logic, one, and that one the most immediate use, is the establishment of clear and determine ideas: in relation to whatsoever discourse we employ on any subject of importance $[\ldots]$ ".
} 
linguagem fosse usada como mitificação de leis para confundir os reais interesses dos indivíduos. Ou seja, o autor propunha uma limpeza da situação verbal como essencial acompanhante do sério estudo das leis.

Segundo o comentador $\operatorname{Hart}^{112}$, Bentham foi um dos poucos, em seu século, a praticar um trabalho árido de método exaustivo, com a finalidade de explanar e desmitificar termos correntes, envolvendo a classificação de detalhes. Tal tarefa era considerada, pelo autor, essencial para a descoberta da verdade da ciência moral e política.

O autor tinha em vista dois pontos essenciais para resguardar os reais interesses dos indivíduos: a) o objetivo, como pensador social, de limpar a mente humana de falácias ${ }^{113}$ dogmáticas até então postas como imutáveis ${ }^{114} \mathrm{e}$ b) mostrar à sociedade que há partes que lucram com a manutenção de falácias legais ${ }^{115}$.

Outro importante fator que motivou Bentham a teorizar princípios e detalhes sobre a legislação, com vistas a garantir o máximo de felicidade para qualquer comunidade, foi o estado de caos em que a França se encontrava no período subseqüente à revolução francesa. Após os excessos da revolução, Bentham decidiu apoiar a reforma do parlamento inglês, negando a linha de declaração dos direitos universais do homem.

\footnotetext{
${ }^{112}$ Sobre isto cito Hart em Essays on Bentham p.3: “[...] But Bentham was unique in his time in undertaking what he himself acknowledge as the fatiguing and sometimes arid labours of the exhaustive method (...)".

${ }^{113}$ A respeito disto cito Bentham em The Book of Fallacies,380 : "[...] Fallacy is an appellation applied not to exclusively to an opinion or to propositions enunciative of supposed opinions but to discourse with or without design, to cause any erroneous opinion already entertained, to cause any pernicious course of action to be engaged to persevered in (...)".

114114 A respeito disto cito Bentham em The Book of Fallacies 381: "[...] Under the name of the Treatise on Political Fallacies, this work will possess the character, and, in so far as the character answers the design of it, have the effect of a treatise on the art of government: - having for its practical object and tendency, in the first place, the faciliting the introduction o such features of good government as remain to be introduced: in the next place giving them perpetuation - perpetuation, not by means of legislative clauses aiming directly at the object (an aim of which the inutility and mischievous will come to be fully laid open to view in the course of this work,) but by means of that instrument, viz. reason, by which alone the endeavour can be productive of any useful effect [...]".

115115 A respeito disto cito Bentham em The Book of Fallacies 475 : "[...] The causes of the utterence of these fallacies may,it should seem, be thus denominated and enumerated:-1.Sinister interest - self-concious sinister interest.2. Interest-begotten prejudice.3. Autority-begotten prejudice.4. Self-defence, i.e. sense of the need of selfdefence against counter-fallacies.
} 
O autor negava o pensamento obscuro que, para ele, significava a destruição e crítica de idéias vigentes, sem uma concepção sustentável que pudesse substituí-las. Bentham se colocava como um contraponto, ou meio-termo, entre os pensamentos confusos derivados de revoluções (falácias anárquicas) e o conservadorismo (falácias conservadoras). Ele era, então, considerado um reformista radical. O princípio da utilidade era o que dava sustentação a todas as reformas por ele propostas. Este princípio também foi utilizado, por Bentham, para sustentar e criticar (em alguns aspectos) a independência americana.

No que concerne à Inglaterra, Bentham via no código constitucional de sua época, um extremo conservadorismo, ou seja, uma grande repulsa à qualquer tipo de reforma. $\mathrm{O}$ autor dizia que tal código era inversamente proporcional à felicidade do povo, pois este encontrava-se no mais miserável grau de opressão por culpa de interesses sinistros da classe de legisladores ${ }^{116}$.

Assim, Bentham foi movido, em seus escritos, pela repulsa à revolução, bem como pela negação de adoradores da ordem estabelecida. Ele dizia que ambas as situações geravam princípios obscuros que impediam os indivíduos de possuir a clareza necessária em relação a seus próprios interesses. Tal obscuridade incitava, de um lado, a opressão e, de outro, violentas $\operatorname{revoltas}^{117}$.

Para Bentham, a tirania e opressão sempre teriam espaço onde houvesse uma reivindicação pela infalibilidade dos julgamentos políticos e morais. Segundo o autor, a liberdade

\footnotetext{
${ }^{116}$ A respeito disto cito Jeremy Bentham em Prefácio do Constitutional Code p. 2: "[...] At no time have the constituent members of the governing body, at no time has the monarch, at no time have the hereditary aristocracy, at no time have the proprietors of seats in the House of Commons, at no time have the clergy, at no time have the judges, had any better endeavor or desire than swell each of them his own power to its utmost possible pitch. To the weakness of the law taken in its totality, - to its weakness, and not to its strength, are the people indebted for everything in their condition, by which they are distinguished from that country in Europe, whatever it be, in which the people are in the most miserable degree oppressed. And this weakness, from what source has it arisen? - from the sinister interest and particular situation of the lawyer tribe (...)".

${ }^{117}$ Sobre isto cito Bentham em Constitutional Code p. 46: "[...] Of bad rule, or say misrule, the sensible evil effects in all shapes, are reducible to one or other of two denominations - oppression and depredation [...]”.
} 
de expressão e crítica da tradição vigente são elementos fundamentais, quando considera-se a possibilidade de erro dos julgamentos humanos ${ }^{118}$.

Junto deste clamor pela liberdade de expressão e crítica da tradição, Bentham contesta o comportamento revolucionário, pois este procedimento estaria embasado, ao menos em sua época, na defesa de direitos naturais inalienáveis que, segundo o autor, constituiriam leis falaciosas.

De acordo com Bentham, invocações a direitos naturais serviam tanto para prover motivos que gerassem insurreição constante (não legitimidade do Estado), quanto para fornecer um inadequado embasamento às idéias morais e políticas ${ }^{119}$. Ou seja, Bentham pensava que o bem-estar geral de uma comunidade estaria ameaçado com o emprego de princípios ligados a direitos naturais na base da vida moral e política de uma sociedade ${ }^{120}$.

Isto porque quem funda os direitos é o Estado, então, não haveria possibilidade de existir direitos que fossem anteriores à existência dele. O próprio termo direito, constitui um termo que não existe na realidade e por isto não pode ser dito natural ${ }^{121}$.

Além disso, o autor adota esta posição, pois considera impossível que um Estado garanta, com esta rigidez, tais direitos. A proclamação destes direitos, serviria de motivo para subversão constante e não legitimidade do Estado, na maioria dos casos concretos, dada a severidade e discrepância de suas exigências com a aquilo que é provido na prática.

\footnotetext{
${ }^{118}$ A respeito disto cito Bentham em On The Liberty of Press $p .279$ : "[...] the liberty of the press, operates as a check upon the conduct of the ruling few: and in that character constitutes a controlling power, indispensably necessary to the maintenance of good government [...]".

${ }^{119}$ Sobre isto cito Bentham em Constitutional Code p. 61: “[...] Thus it is that in all these documents, honor and praise bestowed, operates as a bounty upon oppression and depredation, as an encouragement to preserve in all those courses by which human misery in the largest scale is produced [...]".

${ }^{120}$ A respeito disto cito Hart em Essays on Bentham p. 15: "[...] Bentham insisted that no political principles with the rigidity of the doctrine of inalienable specific rights could have any application in the real world in which men have to live their lives. Such principles belong to Utopia: that is nowhere or an imaginary world [...]".

${ }^{121}$ A respeito disto cito Bentham em, Anarchical Fallacies p.501: "[...] That there are no such things as natural rights -no such things as natural rights opposed anterior to the establishment of government -no such things as natural rights opposed to, in contradistinction to, legal: that the expression is merely figurative [...]".
} 
O autor critica a implementação dos direitos naturais quando figura como condição para que um determinado Estado triunfe. Esta reivindicação requereria que a o Estado surgisse sob a tutela de indivíduos voluntariamente unidos, com a finalidade de proteção privada e alguns direitos garantidos de antemão. Leis, tendo como fundamento este tipo de modelo, para Bentham, não possuem relevância em um mundo onde Estados não nascem desta forma ${ }^{122}$.

O autor faz uma comparação destes direitos inalienáveis (naturais) com o bem-estar geral de uma comunidade, e a partir disto chega à conclusão que tais direitos poderiam ser, meramente, direções ideais para que os governos façam o melhor que podem pelos interesses individuais $^{123}$. Contudo, a rigidez de aplicação que os direitos inalienáveis exigem tende a provocar levantes que tem como resultado prejudicar, constantemente, o bem-estar geral. Ou seja, leis ancoradas em direitos naturais não garantem o bem-estar geral da comunidade uma vez que têm a tendência de causar mais dor do que benefício a ela.

Desta forma, ambas as situações (falácias derivadas do conservadorismo e princípios confusos resultantes de revoluções), descritas acima, propiciavam a sustentação de argumentos falaciosos, retóricos e despóticos, inclusive por intelectuais. Assim, Bentham passa, facilmente, de crítico de fatos para crítico da linguagem e idéias.

O autor insiste na utilidade prática de seus estudos e diz que todos eles são ramos subordinados ao entendimento da felicidade humana, inclusive no que concerne a seus estudos sobre lógica ${ }^{124}$. Seus escritos de lógica constituem um importante instrumento de reação ao

\footnotetext{
${ }^{122}$ Sobre isto cito Bentham A Fragment on Government p. 262: “(...) In like manner, with respect to an original contract, we are given to understand that such a thing never existed that notion of it is even ridiculous (...)”.

${ }^{123}$ A respeito disto cito Hart em Essays on Bentham: "[...] Bentham of course realized that defenders of the doctrine would disclaim such,rigid unqualified interpretations of it, and while limitations of scope, qualifications and exceptions and balancing, both of right against right and right against general welfare, or might even be content to view them merely as ideal directions to governments to do the best they can for certain individual interests (...)".

${ }^{124}$ A respeito disto cito Bentham em Essays on Logic p. 222: “(...) Logic, like every other branch of art and science, in a word, like everything else, is not any otherwise, nor any further deserving of regard, than in so far as it is capable of being in use. But of use in any intelligible sense, neither can this, nor anything else ultimately be, any
} 
conservadorismo e mitificação das idéias vigentes, entre eles (conforme mencionado no capítulo segundo): encontra-se a importância de sustentar uma proposição inteira para a mais simples compreensão de termos que queremos explicar. Conforme mencionado no capítulo anterior, Bentham acrescenta, ainda, que o uso de termos é o resultado de abstração e análise de formas sentenciais ou proposicionais. Esta é a idéia de que sentenças e não palavras constituem a unidade do significado. Ou seja, as palavras (especialmente os termos ficcionais) não possuem significado fora de sentenças ${ }^{125}$.

Bentham discorda da maneira como se definiam termos na filosofia antiga, a saber: por genus et differentiam. Segundo o autor, os termos eram definidos separadamente de proposições (conforme mencionado no capítulo segundo). Como contraponto a esta forma de definir termos, Bentham possui uma doutrina de Ficções Lógicas. O autor utiliza sua teoria para dissipar a idéia de que termos como obrigação, dever, direito, lei, ética constituíam nomes de entidades misteriosas que esperavam pela descoberta de um significado com sua sucessiva incorporação nas leis e regras sociais. Bentham afirma que pelo fato de que nomes de ficção lógica são confundidos com nomes de entidades reais, eles acabam por serem pensados como se tivessem uma relação simples com a realidade. Segundo o autor, em sua época, tais nomes fictícios haviam crescido e obscurecido o entendimento. Termos fictícios como obrigação, dever e direito, para Bentham, não significam nada fora de sentenças.

A partir de sua teoria, Bentham tenta desmitificar alguns termos recorrentes na linguagem utilizados no jargão legal. Estes termos são chamados, pelo autor, de impostores.

\footnotetext{
further than it has been or is capable of being conducive to the diminution of pain in some shape or other, or to the increase of pleasure. [...]".

${ }^{125}$ Sobre isto cito Jeremy Bentham em Essay on Language p. 322: "[...] This being the case, if nothing less than the import of an entire proposition be sufficient for the giving full expression to any the most simple thought, it follows that no word, being anything more than a fragment of a proposition, no word is of itself the complete sign of any thought $[\ldots]$ "..
} 
Estas palavras aparecem como tendo um senso descritivo e neutro, quando, na verdade, estão ancorados em princípios subjetivos não racionais.

Tais termos escondem uma ideologia conservadora e são, freqüentemente, usados como um disfarce para o mau governo. Bentham dá um exemplo de um destes termos falaciosos, a saber: manutenção da ordem. Segundo o autor, estas palavras são, em muitos casos práticos, utilizadas para esconder ou justificar um governo tirano. Para Bentham, o termo neutro quanto a isso seria obediência ao governo.

Estes são os ataques lógicos e lingüísticos de Bentham à cega autoridade opressiva. É possível afirmar que tais críticas tinham, freqüentemente, em vista modificar a legislação inglesa de sua época.

A partir da posição contrária de Bentham em relação aos fatos correntes de sua época e por meio da construção de uma nova teoria lógica e da linguagem, o autor parte rumo a desmitificação de todo e qualquer sistema legal que não apresente princípios calcados em base sólida. O autor inicia sua crítica demonstrando que a veneração de leis pelo simples argumento da autoridade é uma fraude ${ }^{126}$. Para ele, o ato de desmascarar ou desmitificar tais leis constituía um passo preliminar, fundamental, para a reforma do sistema jurídico de sua época.

Bentham ressalta que as leis, freqüentemente, aparecem descrevendo costumes ou hábitos existentes como se fossem mitos intocáveis. Esta mitificação de leis, para o autor, ocultava o verdadeiro caráter do sistema legal referente a resguardar os interesses de indivíduos que compõe uma comunidade. Como resposta a isto, Bentham argumentava que leis não são nada além de comandos, proibições ou permissões, todos artefatos da mente humana. De acordo com

\footnotetext{
${ }^{126}$ Sobre isto cito Jeremy Bentham em The Book of Fallacies p. 387: “[...] With reference to any measures having for their object tha greatest happiness of the greatest number, the course pursued by adversaries of such measures has commonly been, in the first instance, to endeavour to repress altogether the exercise of the reasoning faculty, by adducing authority in various shapes as conclusive upon the subject of the measure proposed [...]".
} 
sua teoria da linguagem, estes nomes constituem termos de ficção ou ficcionais que podem e devem ser alterados, com vistas a proporcionar o máximo de benefício a indivíduos. Assim, para este autor, não há leis imutáveis em política, mas sim leis racionais mutáveis ${ }^{127}$ constituídas por algum princípio capaz de guiar os legisladores e críticos da lei na tarefa de alterá-las sempre que necessário.

Em outras palavras, o indivíduo deveria compreender que as leis são elaboradas por homens e, portanto podem ser feitas e refeitas. Segundo Bentham, a lei, em política, é algo que o homem acrescenta ao mundo, não que ele encontra no mundo. E é o princípio da utilidade que nos guia na busca de uma boa razão para a formulação de uma lei jurídica.

Assim, nada em suas definições se deve à moralidade vigente. Os padrões morais da época, contidos em leis, não seriam relevantes para validá-las. Ao contrário é o princípio da utilidade que constituiria a base para aceitar ou rejeitar estas regras, sem que, contudo, necessitasse de assistência de revoluções para efetuar tais mudanças. Ou seja, a estratégia para alteração das leis estava centrada em reformas, a partir de uma concepção da fundamentação científica da ação humana, da legislação e da moral. A idéia de reforma como maneira de alterar as leis calcadas em princípios obscuros é aqui considerada como um meio-termo entre revoluções e o conservadorismo (não questionamento das leis).

Exatamente porque Bentham era um reformista e utilizava o princípio de utilidade para embasar suas propostas é que se pode dizer que este princípio também constitui um instrumento para construir um meio-termo entre falácias conservadoras ou argumentos utilizados para que a lei jamais fosse modificada e falácias anárquicas derivadas de revoluções.

\footnotetext{
${ }^{127}$ Note-se, aqui, que Bentham insere-se na idéia de racionalismo neo-clássico, pois coloca as leis como sendo hipóteses que podem ser alteradas com base no critério do balanço de prazer e dor. otese
} 
Além dos direitos naturais que sustentavam revoluções, um dos princípios que Bentham via como base errônea para a manutenção das leis (especialmente na Inglaterra), e que, portanto, não resguardava os reais interesses dos indivíduos, era chamado princípio da simpatia.

Antes de dar início à comparação entre o princípio da utilidade e o princípio da simpatia/antipatia, torna-se necessário apresentar os passos, mostrados pelo autor, referentes à impossibilidade de refutação do princípio da utilidade.

Segundo Bentham, refutar a justeza do princípio da utilidade constitui tarefa impossível. Entretanto, em virtude de uma visão confusa e limitada que se costuma ter deste princípio, é possível que uma pessoa não o aprecie. Bentham ressalta que se este for o caso, se um indivíduo acreditar que vale a pena discutir este tema, torna-se necessário que ele execute os seguintes passos, para que se convença do contrário. A saber:

“(1) façamos com que a pessoa reflita dentro de si mesma se deseja descartar totalmente este princípio. Se ela optar por esta alternativa, peçamos-lhe que considere a que se reduzem todos os seus argumentos, sobretudo em matéria de política. (2) Se a pessoa estiver disposta a isto, façamo-la discutir consigo mesma sobre estas perguntas: estaria ela disposta a julgar e agir sem basear-se em nenhum princípio? Existiria algum outro princípio sobre o qual estaria disposta a basear o seu julgamento e a sua ação? (3) Se a pessoa optou por um outro princípio, levemo-la a examinar satisfatoriamente diante de si mesma se o princípio que acredita haver encontrado constitui na realidade um princípio inteligivel diferente, ou se talvez não seria apenas pseudoprincípio ou mero jogo de palavras, uma espécie de frase estereotipada, que fundamentalmente não expressa nem mais nem menos do que um mero reconhecimento das suas próprias opiniões infundadas - em 
outros termos, o que a referida pessoa denominaria um capricho, se fosse tratado de outra pessoa. (4) Se a pessoa estiver inclinada a crer que a própria aprovação ou desaprovação que dá à idéia de um ato, sem qualquer consideração pelas suas conseqüências, constitui para ela um fundamento suficiente para julgar e agir, façamo-la refletir consigo mesma sobre a seguinte questão: o seu modo de pensar deve ser considerado como norma do reto e do errado para os outros homens? Ou será que a convicção de cada um tem o mesmo privilégio de constituir uma norma-padrão? (5) Se responder afirmativamente à primeira questão, façamo-la perguntar-se a si mesma se o seu princípio não é despótico e hostil a todos os outros homens. (6) Se responder afirmativamente à segunda questão, perguntemos se tal princípio não leva ao anarquismo, e se, caso assim for, não haveria tantas normas do reto e do errado quantos são os homens. Perguntemo-lhes também se, nesta hipótese, não se deveria concluir que, mesmo em se tratando de uma e mesma pessoa, o que é hoje reto amanhã poderia ser errado, sem que haja a mínima alteração na própria coisa. Inquiramos também se, nesta hipótese, não aconteceria inevitavelmente que uma e mesma coisa seria ao mesmo tempo reta e errada, no mesmo lugar. Em ambos os casos, perguntemos se toda a argumentação não chegou ao fim. Perguntemos também se, depois de duas pessoas dizerem "Eu gosto disto", e "Eu não gosto disto, poderão ainda", baseada em tal princípio, ter algo mais a dizer. (7) Caso a referida pessoa diga "Não", alegando que o princípio que propõe como norma de pensar e de agir deve fundar-se na reflexão, perguntemos-lhe a que pontos particulares deve voltar-se a reflexão. Se a reflexão tiver por objeto pontos particulares relacionados com a utilidade do ato, perguntemos-lhe se isto não significa abandonar o próprio princípio e recorrer àquele mesmo princípio contra o qual está combatendo. Se a pessoa responder que a reflexão a ser feita não tem por objeto 
pontos particulares referentes à utilidade, mas outros, perguntemoslhe quais seriam esses outros pontos particulares. (8) Se a pessoa optar por um compromisso, adotando em parte o seu próprio princípio e em parte o princípio da utilidade, façamos com que pergunte a si mesma até que ponto adota este último. (9) Quando a pessoa tiver determinado para si mesmo o ponto até o qual decidiu adotar o princípio da utilidade, façamos com que pergunte a si mesma como justifica o fato de tê-lo adotado até este ponto e por que não o adota na sua totalidade. (10) Admitindo-se que, além do princípio da utilidade, exista algum outro princípio válido que estabeleça o que é reto e o que é errado, e que o homem possa seguir: admitindo-se - o que não corresponde à verdade - que o termo reto possa ter sentido sem referência à utilidade, perguntemos à mencionada pessoa se pode existir o que se denomina motivo, que uma pessoa pode ter para seguir os ditames do princípio: se a pessoa responder que existe tal motivo, perguntemos-lhe qual é, e de que maneira se pode distingui-lo daqueles que nos levam a seguir os ditames do princípio da utilidade. Se o motivo aduzido não for convincente, perguntemos finalmente à pessoa: para que serve este outro princípio?" (Bentham, 1789, p.13).

Como é bastante evidente na passagem acima, a defesa de Bentham referente ao princípio da utilidade é dada por uma seqüência de perguntas e respostas que mostram que as conseqüências das ações sempre devem ser levadas em consideração. O autor pretendeu argumentar que se os efeitos das ações importam, como de fato ocorre, não há como desconsiderar ou refutar o caráter utilitarista na avaliação das conseqüências dos atos, dado que o princípio de utilidade constitui, ele mesmo, uma regra que aponta para importância de levar-se em conta as implicações de uma ação qualquer. 
Assim, ao introduzir o debate metametodológico ${ }^{128}$ entre o princípio do ascetismo, da simpatia/antipatia (que guiava a legislação de sua época) e o princípio da utilidade, o autor salienta que como este último é correto deve-se admitir que todos os princípios contrários a ele são incorretos. Ou seja, o que Bentham vai demonstrar é que os outros princípios existentes diferem de alguma forma do princípio da utilidade, razão suficiente para refutá-los.

$\mathrm{O}$ autor argumenta que um princípio pode diferir do princípio da utilidade de duas maneiras $^{129}$ : a) pelo fato de ser sempre contrário a ele (ascetismo ou busca da dor) ou b) pelo fato de ser às vezes contrário, dependendo do caso (este é designado princípio da simpatia ou antipatia).

O princípio do ascetismo é considerado oposto ao da utilidade, pois aprova as ações na medida em que diminuem a felicidade da parte cujo interesse está em jogo. O princípio do ascetismo foi desenvolvido pelo fato de identificar que alguns prazeres, a longo prazo, trazem maior quantidade de dor do que de benefício. Baseados nesta observação, os defensores de tal princípio esqueceram-se do ponto ao qual haviam partido (cálculo de prazer e dor) e colocaram como correto e meritório a apreciação da dor, rejeitando qualquer tipo de prazer. Segundo o autor, o ponto de partida dos defensores do ascetismo, cálculo de prazer e dor, constitui uma forma de considerar o princípio da utilidade. O esquecimento da utilização deste cálculo para avaliação de todas as ações, bem como a extensão da idéia (de que alguns prazeres, a longo

\footnotetext{
${ }^{128}$ Esse debate pode ser enquadrado como um debate de nível metametodológico[Ciência e Filosofia], para utilizar um outro componente da metodologia da teoria da ciência de Chiappin [MTC], pois trata-se de uma comparação metodológica entre três princípios de construção de metodologias, a saber: o princípio do ascetismo, o princípio da simpatia/antipatia e o princípio da utilidade.

${ }^{129}$ Sobre isto cito Bentham em An Introduction to the Principles of Morals and Legislation p.4: “(...) A Principle may be different from that of utility in two ways: 1. By being constantly opposed to it: this is the case with a principle which may be termed the principle of asceticism 2. By being sometimes opposed to it, and sometimes not, as it may happen: this is the case with another, which may be termed the principle of sympathy and antipathy (...)".
} 
prazo, geram mais dor) para a consideração de todos os prazeres, constitui uma maneira errônea de colocar o princípio da utilidade ${ }^{130}$.

Outro princípio contrário ao princípio da utilidade é o princípio da simpatia/antipatia. O autor diz que esta expressão aprova ou desaprova certas ações, simplesmente, pelo fato de que alguém (especialmente quem ocupa um cargo de juiz) se sente disposto a aprovar ou reprovar determinada ação. Os partidários deste princípio negam a necessidade de buscar um fundamento racional para a punição ou recompensa.

Segundo Bentham, o princípio da simpatia/antipatia, não é um princípio positivo, ele constitui, em verdade, a negação de qualquer princípio. Tal conceito não aponta um critério externo capaz de garantir a orientação das convicções internas. É como se cada convicção fosse norma em si mesma.

O princípio da simpatia/antipatia diz que basta consultarmos nossos sentimentos para colocarmos o selo de aprovação ou reprovação em uma ação. Tudo que os agentes se sentissem propensos a condenar estaria errado. Ou seja, com a utilização deste princípio, a punição se dá na mesma medida em que se odeia e por isso, segundo Bentham, não serviria como norma externa de julgamento.

Muitas vezes este princípio coincide com o princípio da utilidade (quando segue os ditames da benevolência), contudo, não se pode correr o risco de adotá-lo, pois há casos em que ele não é conforme o princípio da utilidade, dado que todos os homens estão dispostos a odiar aquilo que constitui a razão de seu sofrimento, ainda que não constitua uma razão justa. Segundo

\footnotetext{
${ }^{130}$ A respeito disto cito Bentham em Uma Introdução aos Princípios da Moral e da Legislação p. 15: “[...] $O$ princípio do ascetismo foi ideado, ao que parece, por certos especuladores apressados que, tendo percebido - ou imaginado - que certos prazeres, quando colhidos ou desfrutados em certas circunstâncias, trazem como conseqüencia, a longo prazo, dores maiores do que prazer desfrutado, utilizaram este pretexto para impugnar tudo aquilo que se apresenta sob o nome de prazer. Depois de chegarem até este ponto, e esquecendo o ponto do qual haviam partido, tais especuladores avançaram mais, chegando ao ponto de considerar meritório enamorar-se da dor. Como se pode ver, mesmo esta colocação não é outra coisa senão uma aplicação errônea do princípio da utilidade $[\ldots]$ ".
} 
Bentham, a orientação por convicções internas não pode constituir um critério constante como fundamento para avaliação justa de ações.

Assim, o autor conclui que pelo fato de não possuir base para estabelecer-se como princípio capaz de conservar a felicidade de uma comunidade, o princípio da simpatia/antipatia, tende a pecar por severidade excessiva, pois permite que cada qual se torne aos olhos dos outros, inimigo ou até criminoso, sem que, em muitos casos, haja a realização de algum crime de fato (ação perturbadora da felicidade da comunidade).

Desta forma, o autor explicita que a utilidade constitui a única razão pela qual a mencionada ação pode ou deve ser praticada ${ }^{131}$. Outros princípios ou motivos servem apenas para explicar porque esta ou aquela ação foi praticada sem que constitua norma para avaliação de uma ação.

Portanto, levando em conta as reações de Bentham contra o conservadorismo ou resistência a reformas que, segundo ele, oprimiam os indivíduos, bem como sua aversão à pensamentos confusos gerados por revoltas (ou depredação, em suas palavras), o autor encontra um princípio positivo que revela, em todas as circunstâncias os reais interesses de indivíduos ou de uma comunidade (entendida como a soma de indivíduos).

\footnotetext{
131 Sobre isto cito Bentham em Uma Introdução aos Princípios da Moral e da Legislação p.18: “[...] $O$ único fundamento correto da ação, é em última análise, a consideração da utilidade, a qual, se for um princípio correto da ação e da aprovação em um determinado caso, sê-lo á em todos. Muitos outros princípios -ou seja, outros motivos -podem constituir a razão que explica por que esta ou aquela ação foi praticada, porém a utilidade constitui a única razão que explica por que a mencionada ação pode (moralmente) ou deve ser praticada[...]".
} 


\subsection{Outras aplicações do princípio de utilidade de Bentham}

\subsubsection{Aplicação do princípio da utilidade como resposta ao contrato original e à manutenção de promessas}

Apesar de ser mencionada a rejeição da idéia do contrato original, por parte de Bentham, na seção anterior, faz-se uma análise particular deste assunto, neste tópico, ainda como parte da metametodologia do autor. Ou seja, serão mostrados, brevemente, os argumentos de Bentham contrários à tradição filosófica contratualista.

Bentham, em seu primeiro livro intitulado A Fragment on Government, critica a fé infundada em teorias políticas que ditam normas sem estarem ancoradas em algum princípio que esteja de acordo com os interesses dos indivíduos. O autor descreve estas teorias como proposições que o homem aceita, simplesmente por fé ou pelo hábito, sem questioná-las. Regras que são ditas decorrerem da justiça, da reta razão e da lei de natureza e que muitas vezes contrariam os interesses dos indivíduos. Neste livro, o autor faz críticas a um autor chamado Blackstone, que segundo ele, seria um dos responsáveis (junto com tantos outros teóricos), por obscurecer as idéias dos homens, acerca de seus reais interesses.

Blackstone teria sugerido uma maneira pela qual os governos foram formados. Bentham cita o que ele diz: " $A$ única verdade e fundação natural da sociedade são os desejos $e$ medos dos individuos"132 (Bentham, 1776 p. 261). Estes sentimentos levariam os homens a unirem-se voluntariamente e a formar uma sociedade, através de um pacto. Além disso,

\footnotetext{
${ }^{132}$ Sobre isto cito Bentham em A Fragment on Government p. 261: “(...) 'The only true and natural foundations of society', says our author, 'are the wants and the fears of individuals. Not that we can believe, with some theoretical writers, that there ever was a time when there was no such a thing as a society: and that, from the impulse of reason, and through a sense of their wants and weakness, individuals met together in a large plain, entered into a original contract (...)".
} 
Blackstone sugere que haveria, também, um pacto entre o povo e seu rei, pois este último teria a obrigação de tentar prover felicidade a seu povo, enquanto que o povo teria a obrigação de obedecer a seu rei.

Em outros termos, segundo Blackstone, devido aos desejos e medos dos indivíduos seria realizado um pacto entre povo e soberano em que o povo deve manter a promessa de obedecer a seu soberano, enquanto o soberano deve manter a promessa de prover bem-estar a seu povo.

Bentham critica este autor, pois, para ele, a sociedade não possui um começo formal por meio de nenhuma convenção de indivíduos impulsionados pelo medo ou pelo desejo. Para o autor, estes termos como sociedade, estado de natureza, contrato original, confundem e obscurecem as idéias dos indivíduos. Esta terminologia poderia ser reunida toda na palavra sociedade (sempre entendida como soma de indivíduos), pois, por exemplo, o termo estado de natureza não faz o menor sentido, dado que algum tipo de governo, sempre houve ${ }^{133}$. O mesmo ocorre com a idéia de contrato original.

Tais pactos que ocorreriam sob a forma de um contrato original, para o autor, constituem mera ficção que representa uma maneira obscura de tentar conduzir o governo ${ }^{134}$. Ou seja, através do argumento destes pactos, que não representam de maneira alguma a forma como as sociedades se constituem, tenta-se justificar maus governos e confundir os reais interesses dos indivíduos.

Do mesmo modo este pacto de obediência ou de manutenção de promessas que se estabelece entre soberano e povo, nem sempre faz sentido, pois há muitas leis que são opostas à

\footnotetext{
${ }^{133}$ A respeito disto cito Bentham em A Fragment on Government p. 261: “(...) This notion, of an actually existing unconnected state of nature, is too wild to be seriously admitted: and besides, it is plainly contradictory to the revealed accounts of the primitive origin of mankind, and their preservation two thousand years afterwards: both which were effected by the means of single families (...)".

${ }^{134}$ Sobre isto cito Bentham em A Fragment on Government p. 261: “(...) But though society had not its formal beginning from any convention of individuals (...)”.
} 
felicidade dos membros de uma comunidade. Ou seja, é possível que um rei possa impedir a felicidade da maioria sem violar uma lei sequer. Da mesma forma um povo pode ser levado à ruína por obedecer a leis que não o favorecem.

A partir destas críticas ao pensamento fundado em falácias como o contrato original e a manutenção de promessas sem justificativas, torna-se necessário descobrir qual é a verdade a respeito da organização política de uma sociedade.

A pergunta que se coloca para descoberta da verdade em política é: por que os indivíduos devem manter suas promessas? A resposta de Bentham condiz com o princípio de utilidade, a saber: pela vantagem de se viver em sociedade ${ }^{135}$. Ainda, segundo o autor, aqueles que perturbarem os interesses da sociedade, através da quebra de suas promessas, devem ser punidos. O cálculo é de custo benefício (ou dor e prazer), pois o indivíduo calcula os riscos de romper as regras, quando seus interesses são contrários aos interesses da comunidade. $\mathrm{O}$ montante de punição para um crime é uma questão de fato, capaz de impedir o crime, suficiente para que o crime não compense ser efetuado.

Esta é, então, a única razão pela qual o homem deve manter suas promessas: pela vantagem de se viver em sociedade. Este é o único motivo pelo qual reis deveriam respeitar as leis e contribuir para o aumento de felicidade do povo, bem como o povo deveria obedecer a seu rei ${ }^{136}$. Um indivíduo está obrigado a obedecer, apenas, se é seu interesse, caso deixe de sê-lo, não mais será obrigado a tal dever ${ }^{137}$.

\footnotetext{
${ }^{135}$ Sobre isto cito Bentham em A Fragment on Government p. 270: “(...) But, after all, for what reason is it, that men ought to keep their promises? The moment any intelligible reason is given, it is: that it for the advantage of society they should keep them: and if they do not, that as far as punishment will go, they should be made to keep them (...)".

${ }^{136}$ A respeito disto cito Bentham em A Fragment on Government p. 269: “(...) It was still necessary to determine, whether the King in question had, or had not, acted so far in opposition to the happiness of his people, that it were better no longer obey him (...)".

${ }^{137}$ Sobre isto cito Bentham em A Fragment on Government p. 270: “(...) it is their duty to obey just so long as it is their interest, and no longer (...)".
} 
Tendo o argumento de Bentham em vista, o que dizer de um governo que promete fazer algo, ou de alguém que assegura obedecer e na realidade não faz?

O autor pensa que é a consideração da utilidade e não outro tipo de consideração que tem, ainda que ocultamente, dirigido o julgamento de governantes e governados sobre estes assuntos políticos ${ }^{138}$. Suponha que um rei prometa governar de acordo com sua própria vontade, a fim de gerar infelicidade para seu povo. Suponha que um povo prometa obedecer a este rei. Estaria este povo obrigado a cumprir esta promessa mesmo que este governo gerasse dano a este povo?

A resposta de Bentham mais uma vez vai de encontro aos ditames da utilidade, a saber: um povo não está obrigado a obedecer a não ser que haja mais benefício do que danos neste ato. Alguns poderiam dizer que este argumento seria perigoso, pois existem muitas promessas vazias que não deveriam ser feitas, ao contrário, as promessas deveriam ser válidas, pois são as próprias promessas que criam obrigações em si mesmas. Segundo Bentham, esta alegação é falaciosa, pois não é a promessa ela mesma que obriga alguém a cumpri-la, mas sim as circunstâncias que a circundam é que são determinantes para este cumprimento ${ }^{139}$.

Qual seria, então, o princípio que está por trás de um governante prometer governar segundo a lei e de um governado prometer obedecer, também, de acordo com ela? O que está por trás de uma promessa, contrariando o simples valor intrínseco dela (em que alguns acreditam)?

O princípio que está por trás do cumprimento ou não de promessas é o princípio da utilidade (pode ser substituído pelo princípio da maior felicidade "the greatest happiness

\footnotetext{
${ }^{138}$ No que concerne a isto cito Bentham em A Fragment on Government p. 271: “(...) I think beyond a doubt that it is the consideration of utility, and no other, that, secretly, perhaps, but unavoidably, has governed his judgment upon all these matters. The experiment is easy and decisive. It is but to reverse, in supposition, in the first place, the import of the particular promise thus feigned: in the next place, the effect in point of utility of the observance of promises in general (...)”.

${ }^{139}$ Sobre isto cito Bentham em A Fragment on Government p. 271: “(...) That circumstance, then, whatever it be, on which the validity of a promise depends: that circumstance, I say, and not the promise itself, must, it is plain, be the cause of the obligation which a promise is apt in general to carry with it (...)".
} 
principle”) que garante a maior felicidade para todos aqueles cujo interesse está em jogo, como sendo o único fim correto e desejável da ação humana. Tal princípio não depende de nenhuma razão mais alta, mas simplesmente dele mesmo ${ }^{140}$.

Desta forma, o autor rejeita a noção de contrato original e de manutenção de promessas por seu simples valor intrínseco, pois nenhum destes elementos pode ser o argumento capaz de dar sustentabilidade a um governo. Apenas e tão somente o princípio de utilidade, entendido como uma regra que busca as conseqüências reais e potenciais de ações e leis, é que pode fornecer bases sólidas a qualquer governo.

\footnotetext{
${ }^{140}$ A respeito disto cito Bentham em A Fragment on Government p. 271: “(...) Now this other principle that still recurs upon us, what other can it be than the principle of utility. The principle which furnishes us with that reason, which alone depends not upon any higher reason, but which is itself the sole and all sufficient reason for every point of practice whatsoever 


\subsubsection{Aplicação do princípio da utilidade para a construção da regra da maioria de}

\section{Bentham: a solução do problema do meio-termo entre conservadorismo e anarquia}

Como dito anteriormente, o princípio da utilidade pode ser expresso através da expressão "maior felicidade do maior número" ("the greatest happiness of the greatest number") ou "a maior felicidade" ("the greatest happiness").

Tendo em vista as expressões acima descritas como sendo idênticas ao princípio de utilidade, o modelo de indivíduo que enuncia que o agente é auto-interessado e possui uma razão que calcula intertemporalmente e a definição de comunidade do autor (um corpo fictício resultante da soma do número de indivíduos) resta claro que tal princípio, em termos políticos, coincide com a defesa da implementação da regra da maioria, como aquela que melhor expressa a manutenção dos interesses de todos.

Levando em conta este modelo de indivíduo, tem-se que a democracia é a forma de governo que mais fornece elementos para que os membros de uma comunidade possam vigiar os homens do governo, também auto-interessados. Além disso, é a partir dela que a maioria dos indivíduos pode expressar seus interesses da maneira mais segura.

Em outros termos, o indivíduo de Bentham é apenas um, esteja ele em cargos governamentais, esteja ele sem poderes para afetar um grande número de indivíduos. Este indivíduo é auto-interessado e busca maximizar seu prazer. Conforme enunciado anteriormente, nada impede que este indivíduo aja com vistas a gerar prazer ou abster-se de ocasionar dor. Contudo, não se pode contar com isto. Para impedir que males maiores sejam efetuados existe a punição e também a democracia ${ }^{141}$.

\footnotetext{
${ }^{141}$ Sobre isto cito Bentham em Constitutional Code p. 47: “(...) A democracy, then, has for its characteristic object and effect, the securing its members against oppression and depredation at the hands of those functionaries which it
} 
Ou seja, os interesses dos indivíduos que estão no governo podem ser diferentes do interesse do bem comum, uma vez que o indivíduo enxerga com maior clareza seus interesses imediatos, que muitas vezes significa obter os benefícios governamentais, sem pagar o seu custo.

Para que o governo consiga maximizar utilidade, que é o mesmo que promover o bem comum, é necessário que o Estado consiga diminuir, o máximo possível, o conflito entre interesse individual e coletivo. Isto é possível através da forma de governo democrática ${ }^{142}$ (quando se trata de vigiar os homens do governo) e de estímulos que a lei possa oferecer para modificar dos motivos dos indivíduos, fazendo coincidir interesse individual e coletivo. Ou, em suas palavras, fazer fortalecer os motivos sociais nos indivíduos.

A regra da maioria aparece, então, como um preceito óbvio a ser abraçado, tendo em vista o fato de que a unanimidade é, operacionalmente, difícil de ser obtida. Ou seja, para ele, a regra que mais se aproxima da unanimidade é a mais óbvia a ser adotada.

Bentham defendia o sistema eleitoral de maioria comparativa (significa que o candidato que receber o maior número de votos ganha as eleições) e não absoluta (significa que o candidato que ganha é aquele que possui mais votos que todos os outros candidatos juntos), por ser mais simples de ser colocado em prática.

Outras justificações, quanto à adoção de Bentham a esta regra, poderiam ser as seguintes: 1) em primeiro lugar os eleitores não precisam julgar diretamente quais são os interesses da maioria, mas sim quais são os candidatos mais aptos a decidirem quais são esses interesses e 2) alguns grupos que defendam interesses sinistros podem ser inibidos ao mesmo

employs for its defense, against oppression and depredation at the hands of foreign adversaries, against such internal adversaries as are not functionaries (...).

${ }^{142}$ A respeito disto cito Bentham em Constitutional Code p. 47: “(...) The only species of government which has or can have for its object and effect the greatest happiness of the greatest number, is, as has been seen, a democracy (...)". 
tempo em que: a) este grupo cresça e ele fique menos coeso e b) os eleitores, (com o sufrágio universal), percebam e votem em candidatos que defendam seus interesses (o da maioria) ${ }^{143}$.

Bentham diz que é necessário tomar como existentes interesses sinistros ${ }^{144}$, pois a ocorrência destes tipos de interesses é um problema decorrente do próprio exercício do governo. Assim, a confiança nos funcionários do governo deve ser minimizada. Este é um conselho que, segundo o autor, não dever ser ignorado por aquele que colocar em prática o código constitucional de seu país. O autor ressalta que devemos confiar nos governantes apenas no estrito limite da necessidade, ou seja, é fundamental a imposição de instrumentos de restrição às oportunidades de abuso de poder por parte dos governantes ${ }^{145}$.

De todos os grupos de interesses sinistros, os mais perigosos, para Bentham, são os grupos que não representam a maioria, mas que se unem em busca de um interesse comum, com reais chances de conseguir acesso ao governo. Para minimizar este risco e para que não haja obstruções aos interesses do maior número, é necessário que reformas sejam efetuadas, no sentido de permitir que a maioria se manifeste através da maioria simples.

Com isto os interesses em promover interesses individuais, sinistros, persistiriam, mas o poder de executá-los cessaria. Ou seja, a partir da democracia com maioria simples seria possível modificar as circunstâncias a fim de que não favoreçam a formação de grupos de interesse. As circunstâncias não favorecedoras da proliferação de interesses espúrios podem ser

\footnotetext{
${ }^{143}$ Este é o argumento da obra: Observations on the Restrictive and Prohibitory Commercial System.

${ }^{144}$ A utilização do termo interesses sinistros decorre da utilização da terminologia de Bentham para expressar interesses funestos.

${ }^{145}$ A respeito disto cito Bentham em Constitutional Code p. 63: “(...) To the devising $f$ any well-grounded and rational course, for the surmounting of the obstacles opposed to good government, by the universal self-preference in the breasts of the functionaries of government-of the constituted guardians of the universal interest-the first step was the taking a true observation of the existence and shape of that some universally prevalent, particular, and sinister interest. The theory being accomplished, correspondent and accordant practice becomes a matter of course (...)".
} 
criadas, de acordo com o autor, garantindo a verdade da seguinte proposição, a saber: cada membro da assembléia eleito deve ter um incentivo para promover somente o bem comum.

Para que esta proposição seja verificada na prática, Bentham propôs três reformas principais: a) parlamentos anuais, b) sufrágio universal e c) segredo do sufrágio. Segundo o autor, a última mudança proposta é de especial importância, pois impediria a influência de grupos mais poderosos e minoritários nos interesses de outros eleitores (que quando somados constituem a maioria). Para ter chance de ser eleito, cada candidato, então, deveria propor melhorias para o bem-comum e não para uma pequena classe em particular. $\mathrm{O}$ voto secreto constituiria a criação de uma circunstância, particular, para que a maioria não fosse coagida a votar em candidatos que, apesar de serem mais poderosos, não visam resguardar os interesses do bem-comum. Tal circunstância poderia ser acompanhada de punição legal, caso grupos poderosos tentassem fazer prevalecer seus interesses sinistros.

Segundo Bentham, uma maneira pela qual os membros de uma assembléia poderiam estar longe do interesse geral da comunidade seria através de faltas às seções (ou por interesse próprio ou por interesse de outro, através de suborno). A proposta para isto é a de que os membros deveriam ser obrigados a ter uma constância de freqüência e estar sempre abertos ao exame público. Além disso, o corpo de representantes deve poder processar, legalmente, aquele que estiver tentando fazer prevalecer seus interesses sinistros (qualquer um que não coincida com os interesses públicos em geral). Estes são apenas alguns exemplos de reformas propostas por Bentham para que a felicidade da comunidade seja resguardada, impedindo o predomínio de interesses espúrios.

Assim, tendo em vista o modelo de indivíduo auto-interessado de Bentham e as oportunidades de transgressões que o sistema governamental criam aos homens do governo (ocasião de impor à sociedade interesses sinistros), o balanço entre prazer e dor (ou aplicação do 
princípio de utilidade) indica que o sistema político que mais tende a respeitar os interesses do maior número possível de indivíduos é o democrático. Para o autor, este sistema consistiria, então, em um conjunto de instituições designadas para coordenar as atividades dos governantes a fim de garantir que os interesses da comunidade (que estão de acordo com o princípio da utilidade) tenham predomínio nos objetivos governamentais.

Entendido que a democracia resguarda, politicamente, a partir de regras formais, a felicidade da comunidade da maneira mais eficiente, parte-se para a compreensão de um nível de análise informal, a saber: a relação do princípio de utilidade com aquilo que consiste ética ou moral, bem como a ligação deste princípio com as causas da imoralidade. Com estas próximas duas seções prepara-se o capítulo quarto para o debate acerca dos limites entre a ética e a legislação. 


\subsection{O princípio da utilidade e seus subprincípioss: As relações da moral com a ética}

Considerando que a ética, em sentido amplo, segundo o autor, define-se como a arte de governar as ações dos homens para a produção da maior quantidade de felicidade, em benefício daqueles cujo interesse está em jogo ${ }^{146}$, é possível levantar a hipótese que esta traz em sua própria concepção, o princípio fundador de todo o sistema de Bentham, a saber: o princípio da utilidade.

Este princípio pode ser traduzido, em um nível menos abstrato, em três outros princípios, quais sejam: a) prudência ou obrigações que um indivíduo tem, para consigo mesmo, b) probidade ou justeza das ações de um homem quando há a possibilidade de gerar dor a outros (o que é o mesmo que benevolência efetiva negativa) e c) beneficência (benevolência efetiva positiva) ou a prática de atos benéficos para com outros indivíduos. Ou seja, a ética se ocupa dos fundamentos do ramo do dever que estejam de acordo com o princípio da utilidade.

Esta separação dos ramos da ética em três outros princípios decorre da necessidade de diferenciar-se as ações dos indivíduos para com os outros de forma positiva, negativa (abstendo-se ou não de gerar dor) e também para circunscrever as ações dos indivíduos para consigo (que não envolvem interações).

No que concerne aos termos moral e ética, assume-se, aqui, a hipótese ${ }^{147}$, de que a distinção entre ambos os temas reside nos níveis de análise. A ética estabeleceria os princípios

\footnotetext{
${ }^{146}$ No que concerne a isto cito Bentham em An Introduction to the Principles of Morals and Legislation p. 42: “[...] Ethics at large may be defined, the art of directing men's actions to the production of the greatest possible quantity of happiness, on the part of those whose interest is in view [...]".

${ }^{147}$ Esta distinção entre estes termos não foi efetuada com clareza por Bentham, contudo, alguns autores como Johnson 1986 p.2 a assume: "[...]Philosophers have generally, for purposes of clarity, confined the usage of the terms moral morality to the realm of practice. When they say that someone is morally they mean that the actions of
} 
e subprincípios metodológicos da ação, enquanto que a moral consistiria em regras de conduta, de um nível menos abstrato (como hábitos e costumes) que devem ser embasadas em princípios éticos.

É interpretação deste trabalho, que o termo moral, em Bentham, aparece como sendo utilizado em duas circunstâncias, a saber: a) baseado na ética quando se refere ao princípio da utilidade como fundamento da moral em contraponto às regras de ação já constituídas em uma sociedade, inclusive fundamentando a elaboração de leis e b) aparentemente não baseado na ética quando a moralidade equivale a um conjunto de costumes e regras já constituídas, que a comunidade informalmente utiliza para julgar ações.

Na primeira circunstância o autor utiliza a ética e o princípio da utilidade como fundamentos da moral. As regras vigentes do campo moral, de uma sociedade, que não estão de acordo com este princípio são consideradas imorais. As leis que não estão de acordo com o princípio da utilidade também são consideradas imorais.

Na segunda circunstância, o termo moral, simplesmente, designa o campo da moral, incluindo os costumes e regras, de uma comunidade, utilizadas, informalmente, para julgar ações: é o que ele chama de sanção moral. Tal sanção corresponderia a uma punição informal que a comunidade impõe a um membro, por uma suposta má conduta. Em vários momentos Bentham se aproxima do senso comum para aceitar ou criticar suas regras correntes, conforme estejam ou não de acordo com o princípio da utilidade.

Segue-se abaixo um exemplo do primeiro sentido, em que Bentham emprega o termo moral como definição baseada na ética, quando se refere a este campo, como um domínio

that person are praiseworthy. Ethics, as we have already said, is a term that refers not directly to practice but rather to theory $[\ldots]$ ". 
a ser reformado pelo princípio da utilidade como seu fundamento, com o objetivo de transformalo em ciência:

"[...] Le mot Déontologie, ou la science de ce qui est bien ou convenable, a été choisi comme plus propre que tout autre à représenter, dans le domaine de la morale, le principe de l'utilitairianisme, ou de l'utilité [...]. (Bentham 1834, p.21).

Este exemplo ilustra o sentido de moral quando baseado na ética, pois tem por fundamento o princípio de utilidade, visto como regra para construir um corpo teórico científico, estando na base das regras informais e formais (legislação) de uma sociedade.

No que concerne ao segundo sentido de moral, percebe-se que este conceito parece tornar-se equivalente a um conjunto de regras já formadas em uma sociedade, inclusive no que diz respeito à condução das ações individuais dos agentes que não possuem conseqüências para outrem. Abaixo segue-se um exemplo deste, suposto, segundo sentido de moral ou moralizador, utilizado por Bentham:

"[...] quanto àquele aspecto da disposição de uma pessoa, cujos efeitos se relacionam em primeira e direita instância exclusivamente com a própria pessoa, não é necessário dizer muito neste contexto. Compete mais ao moralista do que ao legislador reformá-la quando for má: tampouco é ela suscetível daquelas várias modificações que perfazem uma diferença tão relevante nos efeitos da outra [...]”. (Bentham, 1789 p. 72).

No exemplo acima é possível verificar que o termo moralizador sugeriria um sentido diferente de legislador, como se o legislador não fosse, também, um moralizador que emprega o princípio da utilidade para julgar ações. Neste caso, pareceria haver uma diferença de 
natureza entre os instrumentos de avaliação do legislador e do moralista. Sendo assim, indaga-se: qual interpretação utilizar? Aquela que trata a moral como ciência ou esta que sugere que o moralista possui recursos distintos do legislador para avaliar ações?

O presente trabalho interpreta ambas as definições de Bentham como sendo complementares, a primeira referindo-se à moral como um campo a ser explorado de maneira objetiva e científica (utilizando o princípio da utilidade como guia) e a segunda servindo apenas de argumento retórico para que o autor possa dialogar com o senso comum. Ou seja, defende-se, aqui, que o termo moral possui um primeiro, sentido como ciência, embasado em princípios éticos, quando refere-se ao princípio da utilidade como fundamento das ações e das leis. Ao mesmo tempo, o termo moral possui um segundo sentido quando o autor se utiliza deste termo como sendo equivalente a um conjunto de regras informais em uma sociedade. Neste último caso este argumento é retórico e coincide, apenas, aparentemente, com o que a comunidade de sua época entende como aquilo que são costumes ou hábitos. A comunidade utiliza regras já constituídas para julgar ações, a partir da sanção moral.

Não obstante, em ambos os pontos de vista, o guia para julgar se as ações praticadas são imorais ou morais será o princípio da utilidade como princípio que funda a ética. Ou seja, ainda que em alguns momentos o termo moral seja utilizado para designar ações pertencentes aos costumes, os julgamentos de ações por parte de uma comunidade, no âmbito moral, só não serão considerados imorais, se estiverem de acordo com o princípio da utilidade ou o que é o mesmo, estarão de acordo com os três subprincípioss éticos: a) prudência, b) probidade (ou benevolência efetiva negativa) e c) beneficência (ou benevolência efetiva positiva).

Em outras palavras, os hábitos e costumes de uma sociedade também devem passar pela avaliação do princípio de utilidade. Portanto, a imoralidade só deve ser julgada à luz do princípio da utilidade visto como felicidade do maior número possível de indivíduos. 


\subsection{A Imoralidade como causa da aplicação incorreta do princípio da utilidade}

Conforme mencionado no item anterior, todas as ações que forem contrárias ao princípio da utilidade serão consideradas imorais, não importando se o termo moral está sendo utilizado como argumento retórico.

As causas da imoralidade, segundo Bentham, estão sempre relacionadas à aplicação incorreta do princípio de utilidade, conforme se verá abaixo. Estas podem ser compreendidas à luz das seguintes subdivisões:

a) Falsos princípios morais;

b) Aplicações errôneas da religião;

c) Governo dando preferência ao interesse pessoal de seus membros ao invés de beneficiar o interesse social;

d) Preferência dada a um prazer menor, medíocre (porém mais presente) em relação a um prazer maior, (porém mais longínquo).

Os falsos princípios em moral resumem-se ao ascetismo e ao sentimentalismo (ou princípio da simpatia) ${ }^{148}$. Ambos demandam o sacrifício do prazer sem ter em vista um prazer maior no futuro. Estes dois falsos princípios morais não produzem razões sobre as afecções. O ascetismo não dá razões para se ter antipatia por algo e o sentimentalismo não dá razões por se ter simpatia por algo.

\footnotetext{
${ }^{148}$ Sobre isto cito Bentham Déontologie ou Science de la Morale p. 71: “(...) Les faux principes en morale peuvent être compris dans l'une ou dans l'autre de ces deux divisions, l'ascéticisme et le sentimentalisme, qui, tous deux, demandent le sacrifice du plaisir sans utilité, et sans avoir en vue un plaisir plus grand [...] .
} 
Ambos os princípios são tomados como falsos pelo autor, pois tendem a considerar as regras da moral, embasadas na ética (princípio da utilidade), como sendo inúteis. A maldade moral torna-se a regra na prática moral, enquanto que a bondade serve apenas para ostentação e para preencher textos de discursos ${ }^{149}$.

Do princípio do ascetismo e da antipatia nasce o desejo de punir por vingança. Os homens punem segundo a imaginação de que a lei não é mais do que a aplicação de penas de acordo com a vingança. Quanto maior a raiva contra o possível criminoso, mais rigorosa a punição. Segundo Bentham, punir um crime torna-se muito mais um mérito do que uma necessidade, ou seja, é porque os homens odeiam que punem. Para o autor, a aplicação destes critérios errôneos, normalmente, faz com que a pena aplicada ultrapasse a proporção do ato cometido pelo criminoso e não cumpre o papel de impedir crimes futuros.

Bentham levanta a seguinte questão: qual outro guia poderiam aqueles que punem utilizar, ao invés de sua raiva? a resposta é esperada, a saber: o princípio da utilidade. Esta tendência de fazer de nossas antipatias e de nossas predileções a regra da moral é facilmente encorajada na prática, mas se afasta das únicas razões que a torna justa, qual seja: a consideração da felicidade de todos aqueles cujos interesses são afetados por qualquer ação de maneira negativa.

Além disso, a consideração dos motivos como se fossem bons ou maus em si é uma das causas que mais contribuem para desnortear os homens dentro da investigação moral. Esta noção (de motivo) se funda sob um termo vago, que busca a origem da ação, ao invés de avaliar as conseqüências dela. Ou seja, seguindo a axiologia de fins da presente reconstrução

\footnotetext{
${ }^{149}$ Sobre isto cito Bentham Déontologie ou Science de la Morale p.72: “(...) Tous deux tendent à faire envisager les règles de morale comme inutiles, et à confirmer les hommes dans cette idée que la mauvaise morale est pour la pratique $[. .$.$] .$
} 
racional da teoria utilitarista de Bentham, tem-se que a avaliação das conseqüências das ações vem em primeiro lugar, quando se trata de efetuar julgamentos no campo moral e da legislação.

Bentham não quer que os indivíduos julguem ações a partir do estudo dos motivos, pois não importam quais sejam, não são eles que o moralista é chamado a julgar. A relevância dos motivos justifica-se, apenas, quando a condução destes atinge a área do sofrimento ou da dor. Em qualquer outra parte alheia à causa de sofrimento e de dor, em que o moralista tentar opinar, tende a ser déspota ${ }^{150}$.

Outra causa da imoralidade é a aplicação errônea ou falsa da religião. É possível reconhecer esta falsa colocação da religião todas as vezes que a sanção religiosa é aplicada à diminuição da soma de prazer ou ao aumento do somatório de dor. Não há prova mais contundente da falsidade de uma religião do que sua tendência a favorecer a infelicidade, ou a hostilidade em relação à felicidade dos homens.

Bentham ressalta que a religião compreende a vontade de Deus. O autor diz que nos atributos de Deus está a benevolência infinita. Ora, só é possível ser benevolente em relação à proporção de quantidade de felicidade que se produz. A benevolência, necessariamente produz prazer, pois dizer que a benevolência gera dor é uma contradição em termos.

Assim Bentham finaliza sua discussão a cerca da religião, pois argumenta que apenas pretendia tratar dela, no que diz respeito à moral, os outros assuntos referentes a este tema, então, não constituiriam matéria de sua obra ${ }^{151}$.

${ }^{150}$ Sobre isto cito Bentham Déontologie ou Science de la Morale p.73: “(...) Mais quels que soient les motifs, et ils seront toujours identiques, savoir, la recherche du plaisir et l'éloignement de la peine, ce n'est pas eux que le moraliste est appelé à juger : c'est à la conduite seule qu'il s'adresse, la conduite quand ses conséquences atteignent les régions de la souffrance et de la jouissance : partout ailleurs, son intervention serait du despotisme [...].

${ }^{151}$ Sobre isto cito Bentham Déontologie ou Science de la Morale p.74: “(...) Notre objet n'est pas d'explorer ici cette portion du domaine de la pensée qu'occupe la religion, en tant que séparée de la morale. La morale, non la religion, forme le sujet de cet ouvrage. La discussion religieuse serait ici superflue et déplacée [...]. 
Outra causa da imoralidade reside no fato dos governos privilegiarem e protegerem interesses privados, em detrimento de interesses sociais ${ }^{152}$. Uma legislação qualquer deve compreender e unir o interesse popular ao político. Em uma boa legislação, este acordo é verificado, enquanto que em uma má legislação, este acordo é enfraquecido.

A oposição entre interesse público e interesses funestos produz, freqüentemente, a miséria da imoralidade. Para o autor, é fundamental que a maioria conquiste a vitória contra o pequeno número (oligarquia), ou contra o governo de apenas um (monarquia), para que os riscos de que interesses sinistros prevaleçam sejam minimizados ${ }^{153}$. Ao mesmo tempo, a classe de governantes deve ser vigiada garantindo-se a livre expressão ${ }^{154}$ de críticas a ela.

Disto depreende-se que a legislação só cumpre seu papel de resguardar a felicidade da comunidade e assim, segue o princípio de utilidade, quando faz convergir interesses privados e interesses públicos. A imoralidade é produzida quando a lei beneficia a supressão dos interesses coletivos por interesses espúrios, não levando em conta os ditames da utilidade.

A última causa da imoralidade diz respeito à disposição que alguém tenha em preferir um bem menor, porém mais presente, em relação a um bem maior, porém mais longínquo. Bentham diz que o sujeito que evita um mal menor no presente, com o risco ou a certeza de ser vítima de um mal maior no futuro é um sujeito que pede uma atenção especial.

\footnotetext{
${ }^{152}$ A respeito disso cito Bentham em Déontologie ou Science de la Morale p.74: “(...) Il n'est pas inutile cependant de remarquer que cette opposition entre l'intérêt public et des intérêts funestes que la législation ne protège que trop souvent, produit fréquemment la misère et l'immoralité à un degré et dans une étendue véritablement effrayante $[\ldots]$.

${ }^{153}$ Sobre isto cito Bentham em Déontologie ou Science de la Morale p.74: “(...) La victoire obtenue sur le despotisme par le grand nombre contre le petit nombre ou contre un seul, est la victoire de la sanction populaire sur la sanction politique [...].

${ }^{154}$ Bentham era defensor da liberdade de expressão.
} 
É necessário atribuir a fonte deste erro a uma educação defeituosa do ponto de vista intelectual e moral. Pode-se definir este vício, como um falso cálculo de probabilidades ${ }^{155}$, constitui uma estimação errônea do valor dos prazeres e das penas. Em outros termos, este erro representa uma aritmética moral falha dado que não segue corretamente o cálculo dos valores prazeres e dores do princípio da utilidade. De acordo com o autor muitas destas questões morais poderiam ser resolvidas com uma demonstração de rigor matemático ${ }^{156}$.

Desta forma, reconhecidas as quatro causas da imoralidade (falsos princípios morais, aplicações errôneas da religião, governo dando preferência ao interesse privado ao invés de beneficiar o interesse social, preferência dada a um prazer menor, medíocre, porém mais presente, em relação a um prazer maior, porém mais longínquo) como aplicação errônea ou não aplicação do princípio da utilidade, indaga-se: como resolver as conseqüências causadas pela imoralidade? Em outros termos, pergunta-se: como solucionar as conseqüências das ações geradas pela imoralidade?

Tendo em vista o capítulo segundo, depreende-se que a legislação unida a todos os recursos metodológicos elaborados, pelo autor, possui um papel fundamental na solução desta dificuldade. Entretanto resta uma questão, a saber: qual o papel que a ética ou a moral possui para resolver este problema social?

Para responder a estas questões, torna-se necessário estabelecer os limites entre a ética e a legislação. Este assunto será analisado no próximo capítulo com o auxílio do

\footnotetext{
${ }^{155}$ A respeito disso cito Bentham em Déontologie ou Science de la Morale p.74-75: “(...) On peut définir le vice, un faux calcul des probabilités, une estimation erronée de la valeur des plaisirs et des peine [...]..

${ }^{156}$ Sobre isto cito Bentham em Déontologie ou Science de la Morale p.75: “(...) C'est une arithmétique morale fautive, et nous avons la consolation de savoir que, par l'application d'un juste critérion, il est peu de questions morales qui ne puissent être résolues avec une exactitude et une certitude qui approchent beaucoup de la rigueur d'une démonstration mathématique [...] .
} 
instrumental metodológico do capítulo segundo, bem como tendo em vista toda a problemática que envolve o princípio de utilidade, apresentada neste capítulo. 


\section{Capítulo IV}

\section{Os Limites entre a Ética e a Legislação}

“(....) Private ethics teaches how each man may dispose himself to pursue the course most conducive to his own happiness, by means of such motives as offer of themselves:

the art of legislation (which may be considered as one branch of the science of

jurisprudence) teaches how a multitude of men, composing a community, may be disposed to pursue that course which upon the whole is the most conducive to the happiness of the whole community, by means of motives to be applied by the legislator (...)”.

\section{J. Bentham}

An Introduction to the Principles of Morals and Legislation, p. 148. 


\section{1 Introdução: A Apresentação do Problema}

Neste capítulo, pretende-se construir o problema das relações e dos limites entre a ética e a legislação, encaminhando sua solução, com a utilização do instrumental metodológico apresentado no capítulo segundo e considerando todas as implicações que o princípio de utilidade apresenta. Tenciona-se, portanto, verificar qual o espaço que o agir moral, baseado na ética, possui dentro do sistema deste autor, para análise e julgamento das ações que perturbam a felicidade da comunidade.

A hipótese de solução do problema é a de que o próprio princípio de utilidade estabelece a linha divisória entre ambos os campos. Ou seja, é o princípio da utilidade que ditará o raio de ação da lei e da ética, bem como seus limites. Em outros termos, pretende-se mostrar que não há diferença da natureza do conteúdo contido nas regras componentes da ética e da legislação. O desenvolvimento do capítulo consistirá, precisamente, na elaboração dos argumentos e evidências que sustentem a demonstrabilidade desta hipótese.

Colocar o problema sobre a fronteira entre a ética e a legislação, a partir do princípio de utilidade, significa, em última instância, que a solução será conduzida com base no critério de balanço entre prazer e dor ou em termos de prazer líquido (em linguagem moderna pode-se dizer custo benefício) das conseqüências de um ato qualquer. Isto porque, para alguns casos, quando a tendência geral do ato for má, não será vantajosa a aplicação de penas, a partir da legislação, mas apenas através das regras da ética, por meio da sanção moral.

Para que se chegue a esta conclusão, contudo, é necessário ter sempre em mente a tese ontológica do autor e seu modelo de indivíduo, expressos no capítulo segundo: a) o indivíduo é a entidade ontológica fundamental, para análise política, pois é o único que possui 
existência na realidade, b) este indivíduo busca o prazer e foge da dor, ou seja, é auto-interessado e c) o indivíduo possui uma razão que calcula, ele é capaz de fazer cálculos intertemporais, inclusive no que diz respeito às conseqüências das ações.

Além disso, é imprescindível verificar, através do balanço entre prazer e dor, se as ações possuem, de fato, tendência geral má, ou em outros termos, conseqüências más. Cabe lembrar que as ações podem ser de três tipos: a) de um indivíduo para consigo mesmo, b) de um indivíduo para com outros de forma positiva (buscando gerar prazer e c) de um indivíduo para com outros de forma negativa, abstendo-se ou não de gerar dor ${ }^{157}$.

Para realizar julgamento exato das conseqüências de qualquer ação que afeta os interesses de uma coletividade (casos b ou c acima descritos) utiliza-se um critério metodológico de avaliação, também apresentado no capítulo dois. É importante ressaltar que este critério, além de servir para avaliar ações, pode ser útil para vislumbrar possíveis conseqüências de leis formais e de regras informais (como aquelas presentes na moral ou senso comum vigente). Tal critério é utilizado para testar a conformidade destas leis e regras com o princípio da utilidade (a maior felicidade dos membros de uma comunidade).

A descrição deste critério refere-se ao balanço entre prazer e dor, exposto no capítulo segundo. Retomando-se, brevemente, a idéia, leva-se em conta que a apresentação deste critério inicia-se pela consideração da pessoa cujos interesses pareçam ser mais imediatamente afetados pelo ato. Para este indivíduo examinam-se elementos como o valor de cada prazer ${ }^{158}$ produzido em primeira instância, o valor de cada prazer produzido pelo ato após o primeiro

\footnotetext{
${ }^{157}$ Sobre isto cito Bentham em Uma Introdução aos Princípios da Moral e da Legislação p. 70 “[...] Na medida em que a felicidade depende do primeiro setor mencionado, diz-se que a sua felicidade depende da sua obrigação em relação a si mesmo [...]". "[...] Ora, a felicidade de alguém pode ser salvaguardada ou aumentada de duas maneiras [...]": (1) de uma forma negativa, abstendo-se de diminui-la: (2) de uma forma positiva, procurando aumentá-la [...]".

${ }^{158}$ Não se pode deixar de levar em conta que o valor de cada prazer e dor varia de acordo com a intensidade, duração, proximidade ou longinquidade, certeza ou incerteza
} 
prazer, efetua-se o mesmo para a dor e somam-se todos os valores dos prazeres de um lado e os valores de todas as dores do outro. O balanço, se for favorável ao prazer, indicará a tendência boa do ato, para o primeiro indivíduo. Se for favorável à dor, indicará a tendência má do ato, para este mesmo agente. Conforme descrito, faz-se uma avaliação do número de pessoas cujos interesses aparecem em jogo e repete-se o procedimento acima em relação a cada um dos indivíduos, a seguir, aplica-se, então, o princípio de agregação das conseqüências da ação, somando-se $\mathrm{e}^{159} \mathrm{o}$ número de graus de tendência boa com relação a cada um dos indivíduos, realiza-se o mesmo com respeito a cada indivíduo cuja tendência do ato é má e procede-se ao balanço final. Este se for favorável ao prazer assinalará a tendência boa geral do ato. Se o balanço pesar para a dor, teremos a tendência má geral do ato.

Quando o ato possui tendência geral má e, portanto, afeta a coletividade, de maneira negativa, cabe aos governantes manter a felicidade da comunidade (o que é o mesmo que dizer realizar o princípio de utilidade), através da aplicação de penalidades.

Note que o legislador também pode incentivar a boa tendência geral do ato (ou boas conseqüências), por meio de recompensas ou prêmios. Não obstante, cumpre ter presente que Bentham ressalta que a principal maneira pela qual se evita o cometimento de crimes ou atos com tendência geral negativa é através da punição. Devido a este fator, é dado enfoque, neste trabalho, principalmente, aos princípios referentes às penalidades.

Estas penalidades e recompensas constarão em uma legislação. A legislação, por sua vez, será desenvolvida em duas partes: civil (governa a conduta humana) e penal (trata das transgressões às leis civis). Disto, pode-se depreender que o papel das leis (penais e civis) estará circunscrito, especialmente, à interação entre indivíduos, que é capaz de gerar dor (caso c, acima

\footnotetext{
${ }^{159}$ Note que é possível somar as tendências boas e más dos atos, porque qualitativamente e quantitativamente os prazeres, sentidos por cada indivíduo, são comparáveis são ditos "pathological” ou em outros termos físicos.
} 
descrito). Em outras palavras, a função das leis (com sua estrutura de penalidades e recompensas aliada a um poder coercitivo) é a de evitar o cometimento de injúrias (ou geração de dor) dos indivíduos uns aos outros. A criação de leis será o principal meio através do qual a felicidade da comunidade será resguardada.

No que diz respeito ao código civil, a ação humana será regulada por meio de leis que criam direitos e obrigações, com vistas à elaboração de um mecanismo de coordenação da interação coletiva entre os indivíduos. A transgressão desses direitos constitui ofensa que é matéria das leis contidas no código penal. Como tratado no capítulo segundo, a obrigatoriedade ou necessidade de punir uma ofensa é proporcional à perturbação da felicidade da comunidade e à perniciosidade do ato. Contudo, toda punição é em si mesma um mal (por causar dor), portanto, de acordo com o princípio da utilidade, uma punição só pode ser admitida na medida em que evite um mal maior ${ }^{160}$.

Ou seja, o objetivo das leis é evitar danos causados por um ato, principalmente, por meio da punição, quando esta for mais vantajosa que o prejuízo por ela gerado. Quando for benéfico (balanço favorável ao prazer), do ponto de vista da sociedade, o legislador, baseado no princípio da utilidade, deve levar em conta os quatro critérios de proporcionalidade de construção de leis penais ${ }^{161}$, apresentados no capítulo segundo.

Mas qual seria o papel da ética (ou de outras regras informais que regulam a ação humana) visto que a legislação cumpre os objetivos de garantir a maior felicidade da comunidade, no que tange à interação, que é passível de gerar dor, entre indivíduos?

\footnotetext{
${ }^{160}$ A respeito disto cito Bentham em Uma Introdução aos Princípios da Moral e da Legislação p. 65: “[...] Acontece, porém que toda punição constitui um ato pernicioso: toda punição constitui, em si mesma, um mal. Por conseguinte, com base no princípio da utilidade -se tal princípio tiver que ser admitido -, uma tal punição só pode ser admitida na medida em que abre chances no sentido de evitar um mal maior [...]".

${ }^{161}$ A respeito disto cito Bentham em Uma Introdução aos Princípios da Moral e da Legislação p. 66: "[...] Quando valer a pena, existem quatro objetivos ou objetos subordinados que o legislador, inspirado no princípio da utilidade, espontaneamente terá em vista, no decurso dos seus esforços no sentido de atingir de tal forma, que não haja possibilidade de se cometer nenhuma ofensa ou crime [...]".
} 
Tendo em vista que as ações podem ser de três tipos (reitera-se: de um indivíduo para consigo mesmo, de um indivíduo para com os outros de forma positiva e de um indivíduo para com os outros, abstendo-se ou não de gerar dor) e que a legislação se ocupa, principalmente, com a interação entre indivíduos, passível de gerar dor, poder-se-ia depreender que o espaço do agir moral ficaria restrito ao campo da ação de um indivíduo para consigo e de um indivíduo no que tange à geração de prazer aos outros.

Contudo, haverá espaço para a ética, também, nas interações entre indivíduos passíveis de gerar dor, pois há casos em que a punição não traz um benefício suficiente capaz de superar a dor que gera.

Em linguagem atual, podemos dizer que este exame será aquele entre custo e benefício, pois, em muitos casos, a elaboração da legislação e aplicação de punição a determinadas transgressões incorrerá em custos superiores ao benefício auferido. Ou seja, para alguns tipos de contravenções, a legislação não deverá ser aplicada, mas apenas e tão somente as regras da ética, a partir do agir moral.

Em outras palavras, será o próprio princípio de utilidade, entendido como o princípio que visa o maior benefício para a comunidade, que enunciará onde a ética deve atuar, bem como a legislação.

Para delimitar a fronteira entre a ética e a legislação, será discutido, na seqüência, a estrutura e objetivos da legislação, da ética ou agir moral e por fim será efetuada comparação entre ambas. 


\subsection{A Concepção de Legislação segundo Bentham}

\subsubsection{O método de construção de Bentham: como construir um corpo teórico científico}

A construção da legislação é um ponto fundamental dentro da obra de Bentham, pois consiste no principal meio através do qual se busca promover o objetivo de obter a maior felicidade possível para determinada comunidade. É a partir da elaboração da legislação que ocorre, quando vantajoso, a organização de todas as relações entre os indivíduos: políticas, sociais, econômicas, etc.

As primeiras indagações que surgem por meio do estudo deste tema são: qual é a característica essencial do termo lei? o que significa lei para Bentham? qual a natureza de seu constrangimento? como se torna válida? o que deve constar na lei? quais seus objetivos? de que forma estes objetivos são cumpridos?

Para que se entenda o significado de lei, torna-se necessário retomar, brevemente, o recurso metodológico utilizado para operacionalizar a tese epistemológica de Bentham, expressa no capítulo segundo da dissertação. Pode-se dizer que sua teoria da linguagem inclui duas classes de entidades: a) a perceptiva e b) a inferencial. Tais entidades podem ser tanto reais quanto ficcionais. Entidades reais são aquelas que possuem existência na realidade, tais como: substâncias corpóreas e impressões dos sentidos.

Portanto, a tese ontológica, do autor, no que concerne à política (o que existe para Bentham na realidade, para análise política), identifica o indivíduo, prazer e dor com entidades reais, ou seja, os princípios da moral e da legislação de Bentham são construídos a partir de considerações a respeito do modelo de funcionamento deste agente. 
Tendo em vista o modelo de indivíduo, conclui-se que ontologicamente, para o ramo de estudo político e ético, aquilo que existe é o agente, dotado de duas entidades reais denominadas prazeres e dores ${ }^{162}$. Estas são as entidades por meio das quais ele se relaciona consigo mesmo, com os outros e com o mundo.

As entidades fictícias são expressões da linguagem que não podem ser reduzidas gramaticalmente a nomes reais, tais como os substantivos lei e ética. Estes são nomes de entidades fictícias ou nomes ficcionais que não existem na realidade. Leis, direitos, obrigações, ética são ditos existir, mas não podem ter sua existência descrita na realidade das coisas, como é possível fazer com as entidades reais. Ou seja, apesar destes termos não serem reais, mas sim criações, eles podem ser ditos existir, de certa forma, pois afetam o comportamento humano, produzindo conseqüências em termos de prazer e dor (entidades reais).

Em outras palavras, apesar desta separação entre nomes reais e ficcionais, pode-se dizer que há uma conexão entre ambos os tipos de termos, pois quando dizemos que temos uma obrigação a ser cumprida ela é verdadeira e real, em certa medida, uma vez que é passível de ocasionar dor. Além disso, todo termo ficcional possui uma relação com um termo real, através de uma concepção que surge a partir desta relação e passa a explicar o termo ficcional ${ }^{163}$.

Ou seja, termos como lei, apesar de guardarem alguma relação com o que tange o real, não possuem existência na realidade tal como as substâncias corpóreas que experimentamos

\footnotetext{
${ }^{162}$ Sobre isto cito Bentham em A Table of Springs of Actions p. 211: "[...] Among all the several of psychological entities, the names of which are to be found either in the Table of Springs of Action, or in the Explanations above subjoined to it, the two of which are as it were the roots, - the main pillars of foundations of all the rest, -the matter of which all the rest are composed -or the receptacles of that matter-which soever may be the physical image, employed to give aid, if not existence they have not been already, seen to be, pleasure and pains. Of these the existence is matter of universal and constant experience. Without any of the rest, these are susceptible of ,- and as often as they come unlooked for, do actually come into, -existence: without these, no one of all those others ever had, or ever could have had, existence [...]".

${ }^{163}$ Vale a pena mencionar a proximidade que existe entre a metodologia de Bentham e a de Hume, pois ambos os filósofos defendiam que apenas termos associados a uma sensação deveriam ser empregados em filosofia. Ou seja, para clarificar a linguagem e o discurso, inclusive político, é necessário que termos ficcionais (como chama Bentham) mantenham alguma relação com os termos reais.
} 
através de nossos sentidos. Isto é o mesmo que dizer que as leis são ficções criadas e podem ser mutáveis pelos seus criadores, no caso presente, os homens.

Disto depreende-se uma característica essencial das leis, qual seja: são construtos da mente humana e por isso não são nem naturais (como as leis da física) e nem divinas, podendo ser alteradas a qualquer momento, sempre no sentido de suscitar mais prazer do que dor.

As leis naturais são, inicialmente, hipóteses que necessitam ser constantemente testadas, para que sejam aceitas como leis da física. Analogamente, as regras produzidas pela sociedade (jurídicas ou morais) também precisam de exame para que figurem como boas regras. O critério de teste é o princípio da utilidade, pois estas regras devem produzir mais prazer do que dor para a comunidade.

Para Bentham, portanto, a lei jurídica tem origem em idéias e na lógica, necessitando de boas razões para justificar sua existência. Em outras palavras, é exigido da lei, através de um cálculo de custo benefício, que ela prove porque é necessária.

Entendido que lei não possui existência na realidade (termo ficcional), define-se qual a natureza do constrangimento da lei, bem como seu significado, para Bentham: toda lei, quando completa, é ou de natureza coerciva ou de natureza não coerciva. Uma lei ${ }^{164}$ coerciva é um comando, uma proibição. Uma lei não coercitiva é uma revogação do todo ou da parte da lei coerciva $^{165}$.

Toda lei coercitiva cria uma ofensa, converte um ato considerado danoso à sociedade em algum tipo de ofensa formal, por meio de um comando positivo ou negativo. Em outras palavras, a lei dá a qualidade de ofensa a um ato, por meio de uma proibição. Ao fazer

\footnotetext{
${ }^{164}$ Note-se que a explicação completa do significado de lei deveria utilizar-se do recurso de paráfrase, seguindo o recurso metodológico de operacionalização da epistemologia.

${ }^{165}$ A respeito disto cito Bentham em An Introduction to the Principles of Morals and Legislations: “(...) Every Law, when complete, is either of a coercive or an uncoercive nature. A coercive is a command [...]".
} 
isto, impõe uma obrigação e produz coerção. Ou seja, a lei cria direitos conferindo benefícios, mas ao mesmo tempo impõe obrigações e converte atos em ofensas, restrições, sendo que tudo o que o legislador distribuirá entre os membros de uma comunidade se reduzirá nestas duas classes: a) direitos e b) obrigações.

Direitos são vantagens ou benefícios, enquanto que obrigações são deveres. Direitos e deveres são simultâneos em sua origem e inseparáveis em sua existência, uma vez que todo dever é uma dor imposta, para gerar benefícios àqueles que ficam de fora dela. Ou seja, sempre que a lei gerar um direito, ocasionará, também, uma correspondente obrigação ${ }^{166}$ ou um peso para a comunidade.

Seguindo o princípio da utilidade, a lei terá, sempre, por finalidade, gerar um benefício maior (um direito maior) em relação a uma obrigação. Estas são as boas razões ou justificativas da lei: criar um benefício ou um prazer maior do que um peso ou dor para a comunidade. Assim, nenhum constrangimento deve ser criado, nenhuma dor deve ser gerada a não ser que haja satisfatórias explicações para isso. Todas as leis devem provar que possuem razões de maior peso para sua criação do que o peso dado às razões que existem contra elas.

Poder-se-ia perguntar porque a lei gera dor. A resposta vai de encontro ao princípio de utilidade, qual seja: porque reduz a liberdade dos indivíduos, uma vez que diminui seu raio de ação, por meio de obrigações. Em outros termos, sempre há uma razão contra cada lei coercitiva, porque toda lei restringe liberdade ${ }^{167}$.

Bentham aponta para o equívoco de sua época a respeito da definição do termo liberdade. Era dito que esta consistia no poder de fazer cada coisa que não ferisse o outro.

\footnotetext{
${ }^{166}$ A respeito disto cito Bentham em Principles of Civil Code p.301: "[...] Rights and obligation, though distinct and opposite in their nature, are simultaneous in their origin, and inseparable I their existence [...]".

${ }^{167}$ A respeito disto cito Bentham em Principles of Civil Code p.301: "[...] But every restraint imposed upon liberty is liable to be followed by a natural feeling of pain (...) It follows, therefore, that no restraint should be imposed, no power conferred, no coercive law sanctioned, with out a specific and satisfactory reason. There is always one reason against every coercive law [...]"'.
} 
Contudo, o autor argumenta que esta não constituía uma boa explicação, pois o poder de fazer o mal também faz parte da liberdade.

Tendo em vista a noção de liberdade de Bentham e a exposição do significado de leis, conclui-se que a primeira é diminuída, quando se criam leis, pois é impossível criar direitos, impor obrigações, proteger a vida humana, sua reputação, propriedade e subsistência, sem abrir mão de liberdade. Ou seja, a lei comanda e proíbe, restringindo a liberdade dos indivíduos.

Desta forma, a lei cria direitos, mas tem como contrapartida a geração de obrigações e ofensas, ou em outras palavras a restrição da liberdade. Por isso, os direitos gerados por ela, devem ser superiores às dores (obrigações) que ocasionará. Este cálculo de custo e benefício, quando favorável ao benefício, constituíra as boas razões para a existência de determinadas leis.

Em outras palavras, dar uma razão para a lei que esteja favorável ao balanço do prazer é estar conforme o princípio da utilidade, pois a lei que gera mais benefício do que dor é aquela que presa pela maior felicidade possível de indivíduos que compõem uma comunidade, nas palavras de Bentham: "To give a reason for a law, is to show that is conformable to the principle of utility”.'(Bentham, 1843 p. 163).

Portanto, é necessário que haja um princípio racional capaz de organizar e dar boas razões à lei. Este princípio, conforme dito, é o próprio princípio da utilidade que profere que leis ou quaisquer outros temas, construídos pelos homens, capazes de produzir prazer ou dor em indivíduos, devem ser elaborados de forma a visar o maior benefício possível.

Contudo, tendo em vista o modelo de indivíduo de Bentham (agentes autointeressados e racionais) questiona-se: Por que este indivíduo auto-interessado segue as leis, ou seja, o que dá validade a elas? 
Sobre a validade da lei, a resposta de Bentham é simples: para que se escreva uma lei é suficiente que se saiba como escrever e para que seja estabelecida é necessário, apenas, que se possua poder para tal. ${ }^{168}$ Contudo, a fim de que os indivíduos reconheçam tais leis como sendo de seu interesse e as aprovem, a fim de que as obedeçam conscientemente, de acordo com suas vontades, é indispensável que estas leis apresentem argumentos que caminhem, sempre, na direção de conferir mais prazer do que dor aos indivíduos que integram uma comunidade ${ }^{169}$. Em outros termos, a lei deve conferir direitos (bem) que sejam de maior magnitude do que a geração de obrigações ou do que a restrição de liberdade (mal) que ocasiona.

Ou seja, é fundamental que os indivíduos enxerguem que faz parte de seu interesse seguir as leis. Em outras palavras, ao lado da força coercitiva que a lei impõe é de extrema importância que os indivíduos tenham vontade (a partir das boas razões que são dadas) de agir em conformidade com ela.

Para que isto ocorra, o legislador deve, sempre, ter em mente que a legislação é uma construção humana (termo ficcional), um construto que pode e deve ser mudado, de acordo com os ditames do princípio da utilidade, qual seja: visar à garantia da maior felicidade possível de todos aqueles cujos interesses estão em jogo ${ }^{170}$.

\footnotetext{
${ }^{168}$ Sobre isto cito Bentham em A Promulgation of Laws p. 159: “[...] For writing laws, it is enough to know how to write, : for establishing them, it is only necessary to possess power. The difficulty consists in establishing good laws. Now good laws are those for which good reasons are assignable: but it is one thing to have established good laws justifiable by good reasons: another thing to have discovered those reasons, and to have presented them to view in the most advantageous light. A third problem, yet more difficult of solution, is to find a common base for all the laws: one unique and clear principle: to shew their harmony with it: to dispose them in the best order: to give them the greatest simplicity and the greatest clearness of which they are susceptible: to find an isolated reason for a law, is to do nothing, A comparative balance for and against is desirable, since we cannot rely with confidence upon a reason, unless we can be assured that there is nothing stronger to oppose to it in a contrary direction (...)".

${ }^{169}$ Sobre isto cito Bentham em A Promulgation of Laws p.161: "[...] But the greatest advantage is that which results from conciliating the approbation of all minds, by satisfying the public judgment, and obtaining obedience to the laws, not from passive principle of blind fear alone, but the concurrence of the will also (...)".

${ }^{170}$ Sobre isto cito Bentham em Principles Of Civil Code 301: "[...] The legislator ought to confer rights with pleasure, since they are in themselves a benefit: he ought to impose obligations with repugnance, since they are in themselves an evil. In accordance with the principle of utility, he ought never to impose a burthen but that he may confer a benefit of the greater value (...)".
} 
Assim, entendido que a lei é um construto humano que ocasiona obrigações, restringe a liberdade e deve apresentar boas razões para sua existência, indaga-se: o que deve constar das leis? do que ela deve ocupar-se? quais são seus objetivos?

Conforme mencionado, Bentham a classificação das ações dos homens, em três tipos de conduta ${ }^{171}$ : a) a ação do indivíduo relativamente a si mesmo (quando ocasiona prazer chama-se prudência), b) as ações de um homem quando outros são envolvidos no que tange a geração ou não de dor (é chamada probidade ou justeza das ações quando há abstenção na geração de dor) e c) a ação do indivíduo com respeito ao outro que envolve prazer (beneficência quando um benefício é suscitado ao outro).

A probidade, ou em outros termos, a forma de agir que impede a geração de injúrias ou dor para com membros da comunidade, constitui a matéria da legislação, pois ambas (tanto a probidade quanto a legislação) têm como objetivo garantir o máximo de felicidade possível para um conjunto de indivíduos que interagem, evitando ou minimizando o mal.

De acordo com o autor, a lei deverá incluir, então, todos os relatos de probidade ou honestidade que ensinem os homens a viverem juntos, sem cometerem injúrias uns aos outros. Ou seja, a lei deverá ocupar-se, especialmente, da ação do indivíduo com o outro, no que tange à possibilidade de geração de dor. Em outras palavras, a lei terá a qualidade de funcionar como meio para impedir que um agente cometa um ato danoso a qualquer membro da comunidade.

É verdade que antes que as leis sejam promulgadas, precisam existir de maneira não escrita. Estas são as leis de jurisprudência que devem estar de acordo com os ditames da probidade para que a garantia da maior felicidade de todos aqueles cujos interesses se encontram em jogo seja assegurada. Estes relatos de probidade (que ensinam os indivíduos a viverem em

\footnotetext{
171 torna-se necessário reiterá-las, para que os tipos de ações sejam classificados quanto ao bem-agir (prudência, probidade e beneficência).
} 
sociedade) estão totalmente de acordo com o princípio da utilidade, dado que prezam pela maior felicidade possível, no que tange aos indivíduos ${ }^{172}$.

Bentham sugere que a legislação é o principal meio pelo qual se garante questões primordiais, na tentativa de gerar o maior benefício possível para os membros de uma comunidade. Estes temas essenciais são: segurança, subsistência, abundância e igualdade.

"[...] The legislator, should have, for his object the happiness of the body politic. In inquiring more particularly in what this happiness consists, we find four subordinate objects: subsistence, abundance, equality and security [...]" (Bentham, 1843 p.302).

Quanto mais perfeita a junção destes elementos, quanto maior o equilíbrio entre eles, maior será a soma da felicidade social, e especialmente, da felicidade que depende das leis.

Pode-se dizer que a lei possui a função ou o objetivo de referir-se a estes quatro objetos: prover subsistência, guardar a abundância, favorecer a igualdade e manter a segurança. A fronteira entre estes objetos não é fácil de ser traçada, freqüentemente, misturando-se e conflitando-se ${ }^{173}$, como no exemplo a seguir: a subsistência é incluída em abundância, contudo, é necessário que sejam mencionadas separadamente, pois a lei pode permitir que muitas medidas sejam tomadas em favor da subsistência, mas o mesmo não seria permito quando feito pela abundância.

Segundo o autor, existe uma relação hierárquica entre estes objetivos da lei, qual seja: subsistência e segurança estão em patamares superiores, enquanto igualdade e abundância

\footnotetext{
${ }^{172}$ Disto depreende-se que o autor é favorável à incorporação de relatos de costumes às leis, desde que passem pelo crivo do princípio de utilidade. Ou seja, Bentham critica o direito consuetudinário quando não está de acordo com o princípio de utilidade.

${ }^{173}$ Sobre isto cito Bentham em Principles of Civil Code p. 302: "[...] The boundaries which separate these objects are not always easily determined: they approach at different points, and are confounded one with the other. [...]".
} 
estão em patamares inferiores de preocupação da lei. O argumento é o de que sem segurança, a igualdade não poderia durar um só dia e sem a subsistência a abundância não poderia existir.

A legislação deve ocupar-se, especialmente, da segurança, pois sobre a subsistência todos se preocupam, mesmo que não haja lei (não é necessário ordenar que se produza ou que se cultive). Os governantes devem legislar sobre a segurança, sobre os frutos do trabalho, pois esta preocupação não será natural e imediata na sociedade ${ }^{174}$.

Para Bentham, segurança e subsistência seriam, então, como a vida e a igualdade e abundância seriam como os ornamentos da vida ${ }^{175}$, dado que não há um homem sequer capaz de viver constantemente em guerra (sem regras para serem seguidas) ou sem alimentos. Desta forma, a igualdade só deveria ser favorecida nos casos em que não causasse injúrias à segurança, apenas quando não ocasionasse distúrbios às expectativas criadas pela lei.

Tendo em vista o fato de que, para o autor, a legislação é o principal meio através do qual a felicidade de uma comunidade pode ser garantida, a segurança torna-se, assim, matéria de fundamental importância a ser prezada pela lei. Isto porque, sem segurança não há como legislar ou fazer com que as leis sejam cumpridas, não há como dar garantias à manutenção da felicidade dos membros de uma comunidade. Em outras palavras, a legislação, para o autor, deve significar um recurso metodológico capaz de governar as ações dos homens de maneira

\footnotetext{
${ }^{174}$ A respeito disto cito Bentham em Principles of Civil Code p.303: “[...] In legislation, the most important object is security. For no direct laws are made respecting subsistence, this object will be neglected by no one. But if there are no laws respecting security, it will be useless to have made laws respecting subsistence: command productioncommand cultivation: you will have done nothing: but secure to the cultivator the fruits of his labour, and you most probably have done enough (...)”.

${ }^{175}$ A respeito disto cito Bentham em Principles of Civil Code p. 303: “[...] Indeed, without security, equality itself could not endure a single day. Without subsistence, abundance cannot exist. The two first ends are like life itself: the two last are the ornaments of life [...]".
} 
permanente $^{176}$, que é o mesmo que dizer governar de forma estável, segura, garantindo a paz e estabilidade.

A segurança deve ser o principal objetivo de garantia da legislação para que esta mesma possa se manter presente como forma de assegurar a maior felicidade daqueles cujo interesse se encontram em jogo. Ou seja, a segurança é condição fundamental para a conservação estabilidade de uma sociedade.

Assim, tendo em vista a característica essencial do termo lei (ficcional), a natureza de seu constrangimento (coerciva), sua explicação (um comando), sua validade (baseada no princípio de utilidade), seus objetivos (assegurar a felicidade da comunidade provendo segurança, subsistência, igualdade e abundância), parte-se para compreender um elemento, final, importante, a saber: qual a estratégia de Bentham para assegurar que os objetivos da lei sejam cumpridos (em particular que a segurança seja garantida)?

A estratégia de Bentham para operacionalizar a aplicação das leis envolve a construção da legislação como constituindo de três códigos: código civil, penal e constitucional.

O código constitucional confere poderes a uma classe (política) particular de pessoas, a serem exercidos com vistas a garantir o bem para a comunidade. Ao mesmo tempo, este código prescreve deveres a estas pessoas as quais os poderes são conferidos.

Os poderes, neste código, são constituídos por leis não coercivas que operam como exceção das leis de natureza coerciva ou imperativa. Por outro lado, os deveres são criados por leis imperativas, aplicadas àqueles cujo poder político é conferido ${ }^{177}$. Por exemplo: o poder

\footnotetext{
${ }^{176}$ Sobre isto cito Bentham em Uma Introdução aos Princípios da Moral e da Legislação p.70: “[...] Na medida em que as práticas em que se manifesta a arte de governar são de natureza permanente, esta arte se denomina geralmente legislação

${ }^{177}$ A respeito disto cito Bentham em An Introduction to the Principles of Morals and Legislations: “(...) The constitutional branch is chiefly employed in conferring, on particular classes of persons, powers, to be the exercised for the good of the whole society, or of considerable parts of it, and prescribing duties to the persons invested with those powers (...)”.
} 
de legislar figura como lei não coercitiva, enquanto que o dever de agir, publicamente, de acordo com os interesses da comunidade deve ser de natureza coercitiva.

No código civil serão estabelecidos os motivos das leis que regulam a conduta dos indivíduos um relativamente ao outro, com o objetivo de evitar dor. Neste código, expõe-se o conhecimento das verdadeiras razões que devem guiar o legislador na distribuição de direitos conferidos e de obrigações impostas ${ }^{178}$.

Ou seja, a lei civil é considerada no momento que confere um direito ou que impõe uma obrigação. O código civil consiste de corpo de assuntos ou leis expositivas que tratam de matérias que os governantes devem prover ou regular, como: segurança, propriedade, transações, condições domésticas, abundância, subsistência e igualdade ${ }^{179}$, conforme já discutido, no presente capítulo.

No código penal serão debatidas as penalidades a serem aplicadas às transgressões relativas às leis que constam no código civil. Portanto, o código penal consistirá, principalmente, de leis punitivas, aplicadas de forma imperativa, ao todo das leis civis. A lei penal será a maneira pela qual os governantes assegurarão coercitivamente e punitivamente os objetivos de prover segurança, igualdade, subsistência e abundância para uma comunidade. Em outras palavras, a lei penal é a maneira através da qual a felicidade do maior número possível pode ser resguardada, quando os agentes praticam ações baseadas em interesses individuais conflitantes com a comunidade.

Esta lei será construída respeitando os seguintes critérios, conforme mencionado no capítulo segundo: a) evitar, na medida do possível e na medida em que for benéfico, qualquer

\footnotetext{
${ }^{178}$ A respeito disto cito Principles of Civil Code in Dumont's Introduction: “[...] What, then is ment by Principles of Civil Law? We intend to express the motives of the laws - the knowledge of the true reasons wich ought to guide the legislator in the distribution of the rights he confers, or the obligations he imposes upon individuals (...).

${ }^{179}$ Sobre isto cito Prnciples of Civil Code in Dumont's Introduction: "[...] Indeed, to what does this part of the laws refer? It treats of every thing which is most interesting to men: of their security, of their property oh their reciprocal and daily transactions, of their domestic condition in the relations to father, husband, child (...)”.
} 
espécie de crime, b) se for inevitável que alguém cometa um crime, o objetivo é induzi-lo a cometer um delito menos pernicioso no lugar de um mais pernicioso, c) uma vez que o criminoso se decidiu por um crime particular, o objetivo é induzi-lo a causar o mínimo de prejuízo possível e d) evitar o crime da maneira menos dispendiosa possível.

A partir destes critérios, pode-se depreender que todo esforço da legislação penal deve ser feito no sentido de impedir ou minimizar os crimes, tendo sempre em vista que a própria punição causa dor. Em outros termos, a dor causada pela punição deve ser, em todos os casos, a menor possível, suficiente apenas para desestimular crimes, quando houver vantagem para a sociedade.

Em linguagem atual, podemos dizer que este exame será aquele entre custo e benefício, pois, em muitos casos, a elaboração de legislação e aplicação de punição a determinadas transgressões incorrerá em custos superiores ao benefício gerado. Portanto, para alguns tipos de transgressão, a legislação não deverá ser aplicada, mas apenas as regras da ética, a partir do agir moral.

Este assunto, será visto nas próximas seções, levando, sempre, em consideração que o único objetivo de um governo deve ser assegurar a maior felicidade da comunidade. Conforme visto, ele cumprirá seu objetivo, criando, por meio de leis, direitos e obrigações. A estes direitos correspondem ofensas de todas as classes que necessitam ser estudadas, para que se apreenda quais atos são passíveis de gerar dano à sociedade.

Tendo em vista esta breve explanação sobre o que constitui a legislação, pretende-se formular, aqui, uma demarcação entre os raios de abrangência da ética e da legislação. Para tanto, isto será feito, inicialmente, a partir da divisão de ofensas, criadas pela lei. A estratégia adotada para resolver o problema da demarcação tem por objetivo que se entenda 
quais atos podem ser tocados pela lei e quais não podem ser abrangidos por ela, mas apenas pela ética, através do agir moral. 


\subsubsection{Atos abrangidos pela lei: classes de ofensas.}

O termo ofensa constitui mais um instrumento metodológico que o autor elabora, com vistas a distinguir os atos que podem ser tocados por algum tipo de punição, daqueles que não necessitam de punição. Segundo Bentham, uma ofensa constitui um ato proibido ou um ato do qual o contrário é ordenado pela lei ${ }^{180}$. A área legal que concerne ao método de lidar com as ofensas é chamada de área penal, conforme enunciado.

De início faz-se necessário realizar uma distinção entre os atos que podem ou não ser considerados ofensas. De acordo com o autor, qualquer ato pode ser denominado ofensa, bastando para isso que esteja em desacordo os hábitos da comunidade ${ }^{181}$. Por outro lado, o bem da comunidade não pode requerer que um ato seja tornado uma ofensa a não ser que seja passível de causar mal (ato detrimental) à ela. Considerando a idéia do autor de que a comunidade ou estado político é visto como um corpo imaginário ${ }^{182}$ constituído por um agregado de indivíduos somados, qualquer ato detrimental efetuado contra um ou mais membros deste corpo ${ }^{183}$ será considerado maléfico ao Estado também. Ou seja, um ato será considerado detrimental (ou maléfico) ao Estado, caso ocasione mal a um indivíduo ou a um conjunto deles. Contudo, tais indivíduos devem ser passíveis de serem assinalados de serem identificados para que possam ser punidos. Remetendo-se aos tipos de ações descritas neste trabalho, pode-se dizer que ou este indivíduo, a ser assinalado, comete a ofensa a si ou aos outros.

\footnotetext{
${ }^{180}$ Restará claro adiante que não cabe punir legalmente todos os tipos de atos maléficos à sociedade. Ou seja, nem todos os atos danosos à sociedade devem ser convertidos em ofensas, alguns atos prejudiciais figurarão no campo da ética.

${ }^{181}$ Sobre isto cito Bentham em Principles of Morals and Legislation p. 97: “(...) Any act may be an offence, which they whom the community are in the habit of obeying shall be pleased to make one: that is, any act which they shall be pleased to prohibit or to punish. But, upon the principle of utility, such acts alone ought to be misguide offences, as the good of the community requires should be made so (...)".

${ }^{182}$ Atentar para tese reduionista.

${ }^{183}$ Note-se que esta idéia da sociedade ou comunidade vista como um corpo de indivíduos somados remete ao Leviatã de Hobbes.
} 
A partir da compreensão de que um ato efetuado contra um individuo constitui uma ofensa ao Estado e tendo vista que uma ofensa constitui um instrumento metodológico para assinalar os atos que podem ser abrangidos pela lei, o autor parte para subdivisão e classificação dos tipos de ofensa, com vistas a entender o raio de sua abrangência, conforme afetem maior ou menor número de indivíduos.

Quando o indivíduo for distinguível, significa que pode ser diferente daquele que comete a ofensa ou pode ser ele mesmo o ofensor. Ofensas que causam mal, em primeira instância, a agentes assinaláveis diferentes dos ofensores são chamadas de ofensas contra indivíduos e constituem a primeira classe de ofensas. Este tipo de ofensa pode ser denominado ofensa privada quando estiver em contraposição a ofensas de segunda e quarta classe, conforme se verá. Quando comparadas a ofensas de terceira classe, podem ser denominadas "private extra regarding ofences" (Bentham, 1789 p.97).

A segunda classe de ofensas ocorre quando indivíduos são alvo de uma ofensa, mas não podem ser assinalados individualmente, ou distinguidos. Esta quantidade de indivíduos atingidos pode representar menor número do que a comunidade ou pode ser de mesmo tamanho que ela. Caso aqueles atingidos pela ofensa somem número inferior à comunidade, pode-se dizer que este conjunto constitui um corpo de indivíduos que pode ser distinto do restante dela. Estes são casos de ofensas a pessoas que moram em uma mesma região (ofensas à vizinhança) ou o caso de ofensas a uma determinada classe de pessoas que apresentem alguma característica que as una. Ofensas contra uma classe de pessoas ou contra indivíduos que residam em uma determinada localidade são consideradas, então, a segunda classe de ofensas. Tais ofensas podem ser nomeadas semi-públicas quando contrastadas às ofensas individuais (primeira classe) e às ofensas públicas (quarta classe). Vale ressaltar que esta ofensa é considerada semi-pública, pois não atinge a totalidade de indivíduos que compõem a comunidade. 
Ofensas que causam mal somente ao ofensor e a ninguém mais configuram a terceira classe de ofensas. Tais ofensas são ditas intransitivas ou "self regarding" (Bentham, 1789 p.98) quando comparadas às ofensas de primeira, segunda e quarta classes. Ou seja, este tipo de ofensa não diz respeito às interações entre agentes. A quarta classe de ofensas é composta pelas ofensas a uma multidão de indivíduos da qual o todo da comunidade é composto. Em outras palavras, estas ofensas são prejuízos causados ao todo da comunidade, neste caso, nenhum indivíduo parece ser mais atingido do que o outro. Esta é a chamada ofensa pública ou ofensa ao Estado.

Há também uma quinta classe de ofensas que é composta por determinados atos que variam conforme as circunstâncias e mais particularmente de acordo com os propósitos a que são aplicados. Estas ofensas são denominadas multiformes ou heterogêneas e dizem respeito a ofensas por falsidade ou ofensas contra verdade. Elas referem-se, especialmente, às ofensas causadas por idéias de teóricos que induzem à infelicidade da comunidade.

Tendo em vista este instrumental metodológico que organiza os atos passíveis de serem tocados pela lei, seguem-se explicações sobre a ética do autor. 


\subsection{A Concepção de Ética de Bentham}

Antes de partir para a explanação do significado de ética, para Bentham, com suas características e decorrências, é importante que se tenha, sempre, em vista a distinção entre ética e moral que se faz, por hipótese, neste trabalho. É verdade que Bentham não explicita esta distinção, contudo, assume-se aqui que a ética se traduz em um princípio ou princípios capazes de organizar as regras do agir moral (religiosas e de costumes em geral), conforme já discutido no capítulo três.

Tendo isto em conta, torna-se pertinente levantar indagações semelhantes às que foram efetuadas para a compreensão da legislação, no que concerne ao entendimento da ética, a saber: qual é a característica essencial do termo ética? qual seu significado? quais são seus objetivos? o que deve constar nela? qual o escopo da ética? qual sua a natureza de seu constrangimento?

A resposta sobre a característica essencial do termo ética, assemelha-se à resposta dada sobre a essência do termo lei, pois também pertence à classe de nomes ficcionais, uma vez que é um termo que não possui existência na realidade. Contudo, da mesma forma que o termo lei, apesar do termo ética não ser real, mas sim uma construção humana, ele pode ser dito existir, de certa forma, pois afeta o comportamento humano, produzindo conseqüências que se traduzem em termos de prazer e dor (entidades reais).

Desta forma, as regras da ética e as regras do agir moral, assim como as leis jurídicas, também possuem a característica essencial de serem construtos da mente humana. Ou seja, estas normas não são nem naturais (como as leis da física) e nem divinas, podendo ser alteradas a qualquer momento, sempre no sentido de suscitar mais prazer do que dor. 
O próprio significado de ética, em sentido amplo, para Bentham, refere-se a um princípio metodológico norteador das regras de conduta do agir moral, para a produção de mais prazer do que dor, ou seja, constitui um princípio construído, pelos homens, que visa o maior benefício de todos. A ética, segundo o autor, pode ser entendida como a arte de governar as ações dos homens para a produção da maior quantidade possível de felicidade em benefício daqueles cujo interesse está em jogo ${ }^{184}$. Ou seja, o sentido geral de ética coincide com o próprio significado de princípio de utilidade, pois é entendido da seguinte forma:

"[...] O princípio que estabelece a maior felicidade de todos aqueles cujo interesse está em jogo, como sendo a justa e adequada finalidade da ação humana, e até a única finalidade justa, adequada e universalmente desejável: da ação humana, digo, em qualquer situação ou estado de vida, sobretudo na condição de um funcionário ou grupo de funcionários que exercem os poderes do governo [...]"..(Bentham, 1789, p.10).

As ações referentes à ética, em sentido amplo, portanto, dizem respeito à condução das ações de indivíduos, com vistas a garantir a felicidade de todos aqueles cujos interesses se encontram em jogo, respeitando o critério metodológico do balanço entre prazer e dor. As ações referentes à ética, em geral, são as ações que estão em poder de um homem dirigir que não são apenas as suas próprias, mas as ações de outros. Com esta noção de ética, remete-se, novamente, à idéia dos tipos de ações descritos neste trabalho (podem ou não envolver interações).

O autor cria um princípio metodológico complementar ao princípio denominado ética em sentido amplo, denominado ética privada. Este conceito também chamado de arte de

\footnotetext{
${ }^{184}$ A respeito disto cito Bentham em An Introduction to the Principles of Moral and Legislation p. 42: “(...) Ethics at large may be defined, the art of directing men's actions to the production of the greatest possible quantity of happiness, on the part of those whose interest is in view (...)”.
} 
autogoverno denota a habilidade de um homem em dirigir as próprias ações. A ética privada refere-se, assim, a dois fatores: a) à felicidade de um indivíduo que dependerá de setores de seu comportamento acerca do qual só ele tem interesse, ou obrigação em relação a si mesmo (chamada prudência quando a ação tende ao prazer) e b) à felicidade de um homem enquanto dependente daqueles setores do seu comportamento que possam afetar a felicidade dos que o rodeiam $^{185}$ (envolve interações entre agentes).

Além das pessoas, outros agentes, como os animais, estão sob a influência do mando humano e são suscetíveis de felicidade ${ }^{186}$, dado que também sentem prazer e dor. Esta constitui uma passagem curiosa da concepção teórica do autor, uma vez que aponta, em seu tempo, século XVIII, para a discussão feita sobre a ética dos animais, em voga apenas nos dias atuais. Não obstante, o autor dar indícios de que este constituiria um assunto relevante a ser tratado, sua obra fica circunscrita, exclusivamente, à ética relacionada a seres humanos.

Retomando a noção de ética em sentido geral e de ética privada, é possível afirmar que a despeito da distinção que se faz entre ambas (a primeira diz respeito à direção da conduta de vários agentes e a segunda refere-se à direção da conduta do agente por ele mesmo), pode-se dizer que as duas possuem por objetivo guiar as normas morais, pelo princípio da utilidade, com vistas a gerar mais prazer do que dor, no cômputo geral do balanço de uma comunidade.

Assim, tendo em vista que o princípio metodológico ético de ação (seja referente à ética privada ou à ética em geral) coincide com o princípio da utilidade, questiona-se qual o conteúdo que deve constar nas normas do agir moral. Segundo Bentham estas regras não são nem

\footnotetext{
${ }^{185}$ Sobre isto cito Bentham em An Introduction to the Principles of Moral and Legislation p. 42: “(...) As to ethics in general, a man's happiness will depend, in the first place, upon such parts of his behaviour as none but himself are interested in: in the next place, upon such parts of it as may affect the happiness of those about him (...)".

${ }^{186}$ Sobre isto cito Bentham em Uma Introdução aos Princípios da Moral e da Legislação p.69: "[...] Que outros agentes existem que, ao mesmo tempo que estão sob a influência do mando humano, são suscetiveis de felicidade? Podem esses agentes ser de duas espécies: (1) outros seres humanos, denominados pessoas: (2) outros animais que, pelo fato de os seus interesses haverem sido negligenciados pelos juristas antigos, forma degradados ao rol das coisas $[\ldots] ”$.
} 
mais nem menos do que os preceitos condizentes com o princípio de utilidade, pois uma ação só pode ser dita correta caso gere mais prazer do que dor e só pode ser condenada caso gere mais dor do que prazer, no cômputo geral do balanço das conseqüências das ações.

Disto é possível depreender que os costumes e hábitos constituintes das regras morais devem, também, passar pelo crivo do princípio de utilidade, pois apesar de existirem existem inúmeros de sentimentos que nos levam acreditar que algo é certo ou errado, estes sentimentos só podem ser instrumentos válidos para condenar a ação de alguém, caso este alguém aja no sentido de gerar dor.

A discussão a seguir, feita no capítulo segundo dos Princípios da Moral e da Legislação, ilustra a posição de Bentham, afirmada acima. Ele se coloca no lugar de um indivíduo que faz julgamentos morais de ações:

"[...] 'But is it never, then, from any other considerations than those of utility, that we derive our notions of right and wrong?' I do not know: I do not care. Whether a moral sentiment can be originally conceived from any other source than a view of utility, is one question: whether upon examination and reflection it can, in point of fact, be actually persisted in and justified on any other ground, by a person reflecting within himself, is another: whether in point of right it can properly be justified on any other ground, by a person addressing himself to the community, is a third. The two first are questions of speculation: it matters not, comparatively speaking, how they are decided. The last is a question of practice: the decision of it is of as much importance as that of any can be.

'I feel in myself", (say you) "a disposition to approve of such or such an action in as moral view: but this is not owing to any notions I have of its being as useful one to the community. I do not pretend to 
know whether it be an useful one or not: it may be, for aught I know, a mischievous one." "But is it then", (say I) "a mischievous one? examine: and if you can make yourself sensible that it is so, then, if duty means any thing, that is, moral duty, is your duty at least to abstain from it: and more than that, if it is what lies in your power, and can be done without too great a sacrifice, to endeavour to prevent it. It is not your cherishing the notion of it in your bosom, and giving it the name of virtue, that will excuse you.'

'I feel in myself', (say you again) "a disposition to detest such or such an action in a moral view: but this is not owing to any notions I have of its being a mischievous one to the community. I do not pretend to know whether it be a mischievous one or not: it may be not a mischievous one: it may be, for aught I know, an useful one.'-'May it indeed', (say I) 'an useful one? but let me tell you then, that unless duty, and right and wrong, be just what you please to make them, if it really be not a mischievous one, and any body has a mind to do it, it is no duty of yours, but, on the contrary, it would be very wrong in you, to take upon you to prevent him: detest it within yourself as much as you please: that may be a very good reason (unless it be also a useful one) for your not doing it yourself: but if you go about, by word or deed, to do any thing to hinder him, or make him suffer for it, it is you, and not he, that have done wrong: it is not your setting yourself to blame his conduct, or branding it with the name of vice, that will make him culpable, or you blameless. Therefore, if you can make yourself content that he shall be of one mind, and you of another, about that matter, and so continue, it is well: but if nothing will serve you, but that you and he must needs be of the same mind, I'll tell you what you have to do: it is for you to get the better of your antipathy, not for him to truckle to it.' [...]".(Bentham, 1789, p.9). 
Fica evidente a partir desta passagem que não há ações boas ou más em si mesmas, ou motivos de ações bons ou maus em si mesmos, o que existe e deve ser levado em conta são as conseqüências das ações, só estas podem ser ditas boas ou más em si, pois só elas possuem a capacidade de gerar prazer ou dor em um indivíduo ${ }^{187}$. Inclusive, os vícios e virtudes só podem ser assim nomeados de acordo com as conseqüências produzidas por determinada ação, ou conforme a potencialidade que tenham de ocasionar prazer ou dor.

Segundo o autor, remeter-se a vícios e virtudes só faz sentido, quando dão origem a dores ou prazeres, respectivamente. Esta concepção do autor, concorda com a interpretação do princípio de utilidade dada neste trabalho, pois aponta para as conseqüências das ações, desviando o foco de avaliação moral de características subjetivas que o indivíduo possa apresentar. Seguindo esta noção, uma disposição virtuosa pode ser visto como mais um recurso metodológico relacionado à produção de prazer e dor. Esta disposição pode ser descrita como aquela que dá origem a um bem físico, na medida em que a produção de seus efeitos requer o sacrifício de um bem menor e talvez individual para a obtenção de um bem maior, contudo, coletivo $^{188}$.

Assim, as inclinações subjetivas que temos ou podemos ter para aprovar ou desaprovar ações, só devem ser levadas em conta, depois de feito um exame com base no princípio de utilidade. Isto porque, não existem razões em reprovar ações de alguém que não gerem dor, no cômputo geral do balanço. Portanto, o bem moral, é dito existir, quando a vontade humana é considerada como um instrumento na produção de um bem físico (prazer) ou na

\footnotetext{
${ }^{187}$ A respeito disto cito Bentham em An Introduction to the Principles of Moral and Legislation p. 69: “(...) The tendency of an act is mischievous when the consequences of it are mischievous: that is to say, either the certain consequences or probable (...)”.

${ }^{188}$ A respeito disto cito Bentham em A Table of Springs of Actions p. 211: “(...) Destitute of reference of the ideas of pain and pleasure, whatever ideas are annexed to the words virtue and vice, amount to nothing more than that of groundless approbation or disapprobation. All language in which these appellatives are employed, is no better than empty declamation. A virtuous disposition is the disposition to give birth to a good-understand always pathological $\operatorname{good}(\ldots)$,
} 
abstenção de geração de uma dor ${ }^{189}$. Em outros termos, o bem moral existe ${ }^{190}$ na medida em que se relaciona a prazer e dor.

Desta forma, esclarecidos os seguintes elementos: a característica essencial do termo ética (termo ficcional), seu significado (um critério para as regras de conduta moral que promova mais prazer do que dor), seus objetivos (promover a felicidade dos indivíduos), o que deve constar nela (regras morais que estejam de acordo com o princípio da utilidade), parte-se para a compreensão do escopo das ações concernentes à ética e a natureza de seu constrangimento.

Tendo em vista as interações entre indivíduos concernentes à ética (ou seja, excluise a parte da ética que trata das obrigações de um homem para consigo próprio), retoma-se a idéia de que a felicidade do próximo pode ser aumentada ou salvaguardada de duas maneiras: a) de forma negativa, abstendo-se de diminuí-la (é a chamada probidade ou benevolência efetiva negativa) ou b) de forma positiva, procurando aumentá-la (beneficência ou benevolência efetiva positiva). Assim, conforme mencionado no capítulo terceiro, o ramo do dever ético ou moral é dividido em três subprincípioss metodológicos: a) prudência ou obrigações que um indivíduo tem, para consigo mesmo, b) probidade ou justeza das ações de um homem quando outros são envolvidos (evitar geração de dor) e c) beneficência ou o agir no sentido de gerar prazer, também, para outros indivíduos.

O grau em que a ética terá influência sobre os ramos do dever acima descritos variará conforme a eficácia da aplicação da legislação ${ }^{191}$. O alcance da abrangência da ética sobre

\footnotetext{
${ }^{189}$ A respeito disto cito Bentham em A Table of Springs of Actions p. 206: “(...) Moral good, is as above, pathological good, in so far as human will is considere as instrumental in the production of it: in so far as any thing else is made of it, either the word is without meaning, or the thing without value. And so in regard to evil (...)".

${ }^{190}$ Considerando a teoria da linguagem de Bentham não se poderia dizer que qualquer termo ficcional existe, uma vez que são ficções da linguagem e não existem na realidade das coisas.Contudo, tocam a realidade de uma certa maneira, quando ocasionam termos reais como prazer e dor.
} 
estes ramos do agir será tratado no próximo tópico, ao ser diferenciada da legislação. Contudo, é possível adiantar que a prudência ou os cuidados de um indivíduo que não envolve outros agentes será um campo restrito ao agir moral, pois, segundo Bentham, só pode ser por um defeito do entendimento que um indivíduo se descuidará das regras de prudência para consigo próprio ${ }^{192}$. Esta afirmação do autor sustenta-se com o modelo de indivíduo traçado neste trabalho, pois assume-se neste modelo que o agente possui uma razão capaz de efetuar cálculos intertemporais com o objetivo de maximizar prazer. Tendo em vista este modelo de indivíduo, pode-se dizer que se o agente cometer estes erros, isto será devido, apenas, a ele próprio e somente ele sofrerá as conseqüências destes atos. Ou seja, não haverá outros indivíduos afetados por seus atos. O argumento corrente de que os homens conhecem pouco sobre si mesmos e precisam de ajuda não é aceito pelo autor, pois, de acordo com Bentham, ninguém conhece mais sobre si do que o próprio indivíduo e, portanto, não há porque haver interferência legal nesta área.

A legislação, portanto, não deve ocupar-se deste ramo ético, uma vez que a felicidade dos indivíduos (que compõem uma comunidade) não sofre risco de ser diminuída, a não ser que consideremos o indivíduo que comete mal a si mesmo. Contudo, mesmo este indivíduo, quando pratica este tipo de ação, não deve ser objeto da lei, uma vez que esta não possui mais informações sobre ele do que ele próprio. Ou seja, o legislador não tem como efetuar leis ou regras de conduta para um indivíduo, no que concerne a setores de seu comportamento que dizem respeito apenas a ele, pois é o próprio indivíduo que possui mais informações sobre si ${ }^{193}$. Além disso, a ação coercitiva do governo, neste caso, pode instaurar um sentimento de

\footnotetext{
${ }^{191}$ A respeito disto cito Bentham em An Introduction to the Principles of Moral and Legislation p. 146: “(...) The degree in which private ethics stands in need of the assistance of legislation, is different in three branches of duty, above distinguished (...)".

${ }^{192}$ Sobre isto cito Bentham em An Introduction to the Principles of Moral and Legislation p. 146: "(...) It can only be through some defect on the part of the understanding, if a man be ever deficient in point of duty to himself (...)". ${ }^{193}$ A respeito disto cito Bentham em An Introduction to the Principles of Moral and Legislation p. 146: "(...) Of the rules of moral duty, those which seem to stand least in need of the assistance of legislation, are the rules of
} 
perseguição aos costumes sociais, pois ela funcionaria como uma censora dos hábitos de alguns indivíduos. Este fator poderia causar prejuízos, como a redução dos motivos sociais (por exemplo, diminuição da benevolência e amor à amizade) nos indivíduos ${ }^{194}$.

No que diz respeito à probidade (agir com os outros de forma a evitar a geração de dor), foi argumentado que este é o grande campo de atuação da legislação, pois esta deve operar, sempre, no sentido de evitar que indivíduos cometam injúrias uns aos outros, uma vez que é seu papel resguardar a felicidade da comunidade ${ }^{195}$, através de punições e recompensas. Desta consideração deduz-se que, haverá espaço, neste caso (da probidade ou agir de forma a evitar dor), para atuação da ética, apenas, quando não for benéfica a aplicação da legislação. Somente nos casos em que a imputação de penas a determinada transgressão for mais dolorosa do que a vantagem que ocasiona.

No que tange ao terceiro aspecto das regras da ética, a saber: a beneficência ou o agir para com outros indivíduos no sentido de gerar prazer, pode-se dizer que este campo ficará circunscrito, especialmente, ao escopo da ética. Isto porque, a qualidade benéfica dos atos dependerá essencialmente da disposição voluntária do agente, isto é: analisam-se os motivos que influenciam os indivíduos a agir beneficamente de maneira espontânea (os motivos sociais como simpatia, amor à amizade ou amor à reputação interferem positivamente no agir de acordo com a beneficência). A própria noção de beneficência impede a atuação legal nesta área, pois ela refere-

prudence. (...) It is plain, that of individuals the legislator can know nothing: concerning those points of conduct which depend upon the particular circumstances of each individual, it is plain, therefore, that he can determine nothing to advantage (...)”.

${ }^{194}$ A respeito disto cito Bentham em An Introduction to the Principles of Moral and Legislation p 146. : “[...] The great difficulty would be in the procuring evidence: an object which could not be attempted, with any probability of success, without spreading dismay through every family, tearing the bonds of sympathy asunder, and rooting out the influence of all the social motives [...]".

${ }^{195}$ Sobre isto cito Bentham em An Introduction to the Principles of Moral and Legislation p 147 : "[...] With regard to that branch of probity which is opposed to offences against property, private ethics depends, in a manner, for its very existence upon legislation. Legislation must first determine what things are to be regarded as each man's property, before the general rules of ethics, on his head, can have any particular application (...)". 
se às ações que são efetuadas de acordo com a livre vontade do indivíduo, não constrangido pelo governo $^{196}$. Contudo Bentham ressalta que o limite da legislação pode ser estendido a este escopo, particularmente, nos casos em que uma pessoa encontra-se em perigo e podemos salvála, sem riscos para nós mesmos ${ }^{197}$. Ou seja, os indivíduos poderiam estar obrigados a salvar outro, legalmente, caso uma determinada situação não ofereça riscos a ele.

Tendo em vista, este panorama geral dos atos que a ética pode abranger, levantamse as seguintes questões: Quais motivos independentes daqueles que possam oferecer a legislação e a religião, pode uma pessoa ter para salvaguardar (probidade) ou promover (beneficência) a felicidade de outra? Em virtude de que motivos, em virtude de que deveres pode uma pessoa ser obrigada a obedecer aos ditames da probidade ou beneficência?

A resposta dada por ele concorda com o modelo de indivíduo traçado neste trabalho, pois os únicos interesses, para praticar a salvaguarda de outros, que uma pessoa possa encontrar, como motivos adequados, são seus próprios interesses ${ }^{198}$, ou seja, reitera-se que o indivíduo é auto-interessado. Não obstante, não existe nenhuma ocasião em que uma pessoa não tenha alguns motivos para promover a felicidade de uma outra, seja devido a motivos sociais (simpatia e benevolência que dependem da sensibilidade do agente), seja por força de motivos semi-sociais (amor à amizade ou à reputação que dependem, da variedade de circunstâncias, sobretudo conforme a eficácia das suas faculdades intelectuais, do quantum de sensibilidade moral e tipos de pessoas com as quais se tenha que tratar). Note-se na frase acima, que se articulam os recursos

\footnotetext{
${ }^{196}$ A respeito disto cito Bentham em An Introduction to the Principles of Moral and Legislation p. 147: “(...) As the rules of beneficence, these, as far as concern matters of detail, must necessarily be abandoned in great measure to the jurisdiction of private ethics (...)".

197 A respeito disto cito Bentham em An Introduction to the Principles of Moral and Legislation p. 147: “(...) The limits of the law on this head seem, however, o be capable of being extended a good deal farther than they seem ever to have been extended hitherto. In particular, in cases where the person is in danger, why should it not be made the duty of every man to save another from mischief, when it can be done without prejudicing himself (...)”.

${ }^{198}$ Sobre isto cito Bentham em Uma Introdução aos Princípios da Moral e da Legislação p. 71: “[...] Em resposta a tal interrogativo, é imperioso admitir que os únicos interesses para cuja salvaguarda uma pessoa possa encontrar, com certeza e sempre, motivos adequados são os seus próprios interesses [...]".
} 
metodológicos do autor com vistas a entender de que forma é possível um indivíduo resguardar a felicidade de outro.

Do modelo de indivíduo auto-interessado que não é obrigado a agir de acordo com os interesses alheios, depreende-se que não existem obrigações morais com força coercitiva, tal como a força que impõe a legislação (através da punição formal e de recompensas), contudo, conforme explicitado no capítulo terceiro, age mais de acordo com o princípio da utilidade aquele que leva em conta, em seus próprios interesses, os interesses de outros. Isto porque gera mais prazer, no cômputo geral, aquele que pratica a probidade ou beneficência para com os outros indivíduos, membros de uma comunidade.

Além destes motivos que os indivíduos possuem para agir no sentido de não causar injúrias a outros, há ainda, um outro estímulo ou fonte de prazer ou dor (nas palavras de Bentham) denominado reprovação ou sanção moral ${ }^{199}$. Conforme dito no capítulo segundo, este constitui um instrumento metodológico que membros da comunidade (especialmente um membro de destaque) podem utilizar para efetuar censura às ações consideradas perniciosas à sociedade.

Em outros termos, é possível afirmar que apesar de não possuir força coercitiva como as leis, a ética também possui um instrumento informal capaz de constranger as ações dos indivíduos, a partir da geração de dor. Este instrumento é a sanção moral que é entendida por

\footnotetext{
${ }^{199}$ No que concerne a isto cito Bentham em An Introduction to the Principles of Moral and Legislation p. 14: “(...) Sanctio, in Latin was used to signify the act of binding, and, by a common grammatical transition, any thing which serves to bind a man: to wit, to the observance of such or such a mode of conduct. According to a Latin grammarian, the import of the word is derived by rather a far-fetched process (such as those commonly are, and in a great measure indeed must be, by which intellectual ideas are derived from sensible ones) from the word sanguis, blood: because, among the Romans, with a view to inculcate into the people a persuasion that such or such a mode of conduct would be rendered obligatory upon a man by the force of what I call the religious sanction (that is, that he would be made to suffer by the extraordinary interposition of some superior being, if he failed to observe the mode of conduct in question) certain ceremonies were contrived by the priests: in the course of which ceremonies the blood of victims was made use of. A Sanction then is a source of obligatory powers or motives that is, of pains and pleasures: which, according as they are connected with such or such modes of conduct, operate, and are indeed the only things which can operate, as motives (...)".
} 
Bentham como uma fonte de prazer ou dor, que se encontra nas mãos de pessoas que por acaso ocupam um lugar de destaque na comunidade. Ou seja, há no agir moral, regras informais não legais, com algum poder de coação, capazes de produzir prazer ou dor em indivíduos, conforme suas ações estejam ou não de acordo com o princípio de utilidade (balanço favorável ao prazer).

Portanto, a natureza do constrangimento da ética, ou mais especificamente, das regras morais é não coercitiva, embora haja um instrumento de coação capaz de constranger ações de indivíduos. Não obstante, é importante que os membros da comunidade que possuem esta força de coação (possuem autoridade reconhecida) tenham, em todos os casos, o princípio de utilidade, como critério válido para julgar as ações e as regras informais pertencentes à moral.

Assim, tendo em vista a característica essencial do termo ética (termo ficcional), o significado deste termo, em sentido geral, (um critério para avaliar as regras de conduta moral e para avaliar ações que tenham em vista produzir a felicidade de todos aqueles cujos interesses estão em jogo), o significado do termo ética privada (um critério que visa a felicidade de um indivíduo nas ações para consigo e para com os outros), seus objetivos (promover a felicidade dos indivíduos), o que deve constar nela (princípios que conduzam as regras morais para que fiquem de acordo com o princípio da utilidade), a natureza de seu constrangimento (não coercitiva, embora possua um instrumento de coação denominado sanção moral) e os tipos de ações que são de seu escopo (principalmente o campo da prudência e benquerença, às vezes o ramo da probidade), parte-se para a demarcação entre o ramo da ética e a legislação.

Conforme mencionado, a hipótese de solução do problema é a de que o próprio princípio da utilidade estabelece a linha divisória entre ambos os campos. Ou seja, é o princípio da utilidade que ditará o raio de ação da lei e da ética, bem como seus limites, conforme se verá a seguir. 


\subsection{Solução do Problema: A Demarcação da Fronteira entre Ética e Legislação}

\subsubsection{Breve distinção entre a ética e a legislação}

Para que se entenda a demarcação entre a ética e a legislação efetua-se, inicialmente, uma distinção entre ambos os temas.

Segundo Bentham, a ética tem por objetivo a felicidade, sendo este também o da legislação, ou seja, ambas apresentam pontos em comum: a) dizem respeito à felicidade e ações de cada um e b) as pessoas cuja felicidade devem ter em vista, bem como os indivíduos cuja conduta devem ocupar-se, são os mesmos.

Levando em conta as três áreas da ação humana: a) ação com ausência de interações (prudência quando maximiza prazer), b) interações positivas (beneficência quando maximiza prazer) e c) interações negativas (probidade quando não se gera dor), foi discutido que a legislação tem como objetivo assegurar a probidade, ou a ausência do cometimento de injúrias, enquanto os grandes campos da ética são garantir a prudência e a beneficência.

Adiantando, de maneira breve, a solução que será dada na parte final deste tópico, tem-se que: a ética tangenciará a probidade, ou o ramo em que os indivíduos podem ocasionar injúrias uns aos outros, somente nos casos em que não for benéfica a aplicação de leis, ou seja, apenas quando mais dor do que prazer for ocasionado a partir do emprego de normas formais. A legislação, de outra parte, não deve interferir nos casos relativos à prudência (casos em que não há interação entre indivíduos), por uma questão de eficiência, pois: a) o legislador não pode criar leis sobre este tema, uma vez que não pode saber mais sobre os interesses de um indivíduo do que ele próprio e b) a ação coercitiva do governo, neste caso, pode instaurar um sentimento de 
perseguição aos costumes sociais, reduzindo os motivos sociais (por exemplo, diminuição da benevolência e amor à amizade) nos indivíduos. No que diz respeito ao agir positivo, a área legal poderá intervir, somente, em casos específicos, como o salvamento de alguém, sem prejuízo próprio. Em outros casos do agir positivo, a aplicação da legislação não faz sentido, pois descaracteriza a natureza do termo beneficência que diz respeito a uma disposição livre do agir de forma a ocasionar $\operatorname{prazer}^{200}$ :

No final deste tópico será dada uma explicação mais detalhada sobre a separação entre os campos de abrangência da ética e da legislação, no que concerne aos três tipos de ações acima descritas. O guia desta separação da atuação de ambos os temas (ética e legislação) será, em todos os casos, o princípio de utilidade (balanço entre prazer e dor das conseqüências das ações), provando que não há diferença de natureza entre o conteúdo da regras que constam na moral e na legislação, ou seja, a diferença reside em cálculo de custo benefício.

Da breve explanação dada acima sobre as distinções entre a ética e a legislação, depreende-se que apresentam as seguintes diferenças: a) os atos com os quais ambas devem ocupar-se, embora sejam convergentes, não são perfeitamente e inteiramente os mesmos, pois o balanço entre prazer e dor delimitará sua distribuição entre os campos de atuação da legislação e ética b) no que toca a legislação existem casos em que o legislador não deve tentar dirigir a conduta dos vários outros membros da comunidade (eventos relativos à prudência, beneficência e parte dos casos de probidade).

Tais diferenças entre ambos os temas ocorrem, pois o princípio de utilidade inscreve, a partir de um cálculo de custo benefício para a sociedade, o raio de atuação da ética e da legislação.

\footnotetext{
${ }^{200}$ A respeito disto cito Bentham em An Introduction to the Principles of Moral and Legislation p. 148: “(...) In many cases the beneficial quality of the act depends essentially upon the disposition of the agent (...)”.
} 
Nas seções anteriores, mostrou-se que a prudência e beneficência ficam sob o escopo da ética, por ser mais benéfico à sociedade, enquanto que a probidade permanece sob o raio de ação da legislação, pelo mesmo motivo. Ora, isto é o mesmo que dizer que o princípio da utilidade determina, através de um cálculo de custo benefício, o raio de atuação de ambos os temas.

Contudo, no que diz respeito ao agir negativo (abster-se ou não de gerar dor) argumentou-se que o legislador não pode impedir todos os atos prejudiciais (ofensas) praticados por uma pessoa contra a comunidade, pois o mal em tentar demover tais atos pode ser maior do que os benefícios auferidos.

Portanto, além dos campos que são próprios da ética, como prudência e beneficência, cabe verificar quais são os casos de intervenção da ética que seriam próprios do setor legal. Em outras palavras, cabe analisar quais casos não se deve punir, mas apenas aplicar a ética.

Antes de analisar estes casos, uma pergunta torna-se pertinente: qual o princípio ou qual pressuposto que estará por traz do argumento de que um caso próprio da legislação não deve estar sob seu escopo, mas sim sob o raio de interferência da ética?

Da mesma forma que o princípio da utilidade determina que a prudência e beneficência devem ser matéria da ética e que a probidade deve ser matéria da legislação, é possível sustentar a hipótese de que será o princípio da utilidade (análise de custos e benefícios da punição, aplicada à sociedade, ou balanço entre prazer e dor) que ditará os limites aos quais o setor penal, legislativo pode atuar. Portanto, os tipos de atos prejudiciais que não podem ser tocados pela lei, por aplicação do próprio princípio de utilidade, constituem a resposta que faltava para a demarcação do campo desta para com a legislação. 
Tendo estes elementos em vista, segue-se a condução da resposta sobre a distinção entre a ética e a legislação, no que concerne aos casos em que não cabe punir. 


\subsubsection{Casos em que não cabe punir}

Conforme reiterado, constantemente, o objeto geral no qual todas as leis têm em comum diz respeito ao aumento do montante total de felicidade da comunidade e, portanto, em primeiro lugar, excluir cada coisa que tende a diminuir a felicidade. Em outras palavras, eliminar o mal. Mas toda legislação e punição produzem um mal. Segundo o princípio da utilidade, um mal é admitido somente para impedir ou excluir um mal ainda maior.

A partir desta consideração sobre o mal, o autor cria mais um instrumento metodológico para entender quais são os males resultantes da punição. O objetivo é subdividilos, para que sejam analisados à luz dos casos em que não cabe punir.

O mal da punição pode dividir-se em quatro partes, por meio das quais diferentes conjuntos de pessoas são afetados: 1) o mal da coerção ou a dor causada em um homem por impedi-lo de realizar um ato, 2) o mal da apreensão, 3) o mal do sofrimento ou a dor que um homem sente em virtude da punição, a partir do momento em que começou a suportá-la e 4) a dor da antipatia ou outros males derivativos resultantes de pessoas que estão em conexão com as várias classes de sofrimentos acima mencionadas. Destes quatro tipos de males: a) o primeiro será maior conforme a natureza do ato que o indivíduo é impedido de realizar e b) os três últimos serão maiores conforme a natureza da punição que acompanha a respectiva ofensa. Por outro lado, o mal causado pela ofensa também será maior ou menor conforme a natureza dela. A proporção entre crime e punição variará conforme a ofensa efetuada.

Tendo em vista estes males causados pela punição, torna-se necessário verificar quais casos não são passíveis de punição, para que estejam de acordo com o princípio da utilidade (balanço favorável ao prazer). É importante ter em conta, os critérios metodológicos ou 
objetivos que devem ser observados para a construção de leis penais, expostos no capítulo segundo e reiterados na segunda seção deste capítulo.

A partir deles conclui-se que todo esforço da legislação penal deve ser feito no sentido de impedir ou minimizar os crimes, tendo, sempre, em vista que a própria punição causa dor. Portanto, o critério de punição, de Bentham, afasta-se, totalmente, da noção de vingança, aproximando-se da idéia de proporcionalidade entre crime e punição. Em outros termos, a dor causada pela punição deve ser, em todos os casos, a menor possível, suficiente apenas para desestimular crimes, quando houver vantagem para a sociedade. Nos casos em que não houver benefício para a sociedade, não é eficiente a aplicação da lei ou de punições.

A constatação de que alguns casos não devem ser tocados pela lei ou pela punição fornecerá importantes respostas sobre a limitação do raio de ação da legislação e sobre a abrangência da atuação da ética, no que diz respeito à interação entre indivíduos, de forma negativa. Em outras palavras, questiona-se: quais casos não devem ser tocados pela lei? dentre os casos que não devem ser tocados pela lei, quais constituem matéria da ética?

Tendo em vista estas questões, apresenta-se, abaixo, a análise dos casos em que a punição legal não deve ser aplicada, de acordo com o princípio da utilidade (balanço favorável ao prazer ou à minimização de dor $)^{201}$ :

a) Quando a aplicação da pena é infundada (groundless): $\mathrm{a}_{1}$ ) não há mal a ser evitado e $\mathrm{a}_{2}$ ) o ato não causa mal ao todo.

b) Quando a punição é ineficaz (inefficacious), em outras palavras, quando nenhuma punição pode evitar o mal a ser causado.

\footnotetext{
${ }^{201}$ A respeito disto cito Bentham em An Introduction to the Principles of Moral and Legislation p. 83: “(...) But all punishment is mischief: all punishment in itself is evil. Upon the principle of utility, if it ought at all to be admitted, it ought only to be admitted in as far as it promises to exclude some greater evil (...)".
} 
c) Quando a aplicação da pena não é proveitosa (unprofitable), ou muito custosa, ou seja, quando o mal causado pela punição seria maior do que o mal que se poderia prevenir, em termos financeiros.

d) Quando a punição é desnecessária (needless): nos casos em que o mal pode ser impedido ou cessar por si só, sem a punição, o que é o mesmo que dizer cessar a uma taxa mais barata.

a) Casos nos quais a aplicação da pena é infundada ${ }^{202}$

Estes casos ocorrem quando nunca houve um mal, quando nenhum mal foi produzido a algum corpo pelo ato em questão. Ou seja, algumas vezes, tal ato foi considerado pernicioso, mas na ocasião ocorrida a pessoa afetada pelo ato dá seu consentimento para a ocorrência dele. Segundo Bentham, ninguém pode ser melhor juiz do que é ou não prazeroso do que o próprio homem afetado por um ato. Em outros termos, se há consentimento, o legislador não deve intervir, pois não pode decidir no lugar do indivíduo o que lhe dá prazer ou dor ${ }^{203}$.

A aplicação da pena também é infundada quando o mal causado pelo ato é superado por um prazer. Em outras palavras, embora um mal tenha sido produzido por um ato, este se fazia necessário para a geração de um benefício de maior valor. Este é o caso em que um mal é efetuado no exercício de vários tipos de poderes necessários a serem estabelecidos em todas as

\footnotetext{
${ }^{202}$ A respeito disto cito Bentham em An Introduction to the Principles of Moral and Legislation p. 83: "(...) Where it is groundless: where there is no mischief for it to prevent: the act not being mischievous upon the whole (...)'”.

${ }^{203}$ A respeito disto cito Bentham em An Introduction to the Principles of Moral and Legislation p. 84: “(...) This consent, provided it be free, and fairly obtained, is the best proof that can be produced, that, to the person who gives it, no mischief, upon the whole, is done. For no men can be so good a judge as the man himself, what it is gives him pleasure or displeasure (...)".
} 
comunidades, a saber: judicial, militar e supremo ${ }^{204}$. Ou seja, para implantação destes poderes custos (ou males) são impostos, sendo, contudo, superados por prazeres ou benefícios gerados.

Além disso, as penas serão consideradas infundadas caso haja a certeza de uma compensação adequada. Esta contrapartida pressupõe dois aspectos: 1) a ofensa é tal que admite adequada compensação e 2) tal compensação certamente virá em futuro próximo ${ }^{205}$.

b) Casos em que a punição é ineficaz ${ }^{206}$

Estes referem-se aos casos em que um ato pernicioso foi cometido antes que constasse na legislação como ofensivo. Bentham diz que o juiz não pode ao seu bel prazer condenar um ato, antes que conste na legislação. Outro caso em que a punição é considerada ineficaz refere-se às situações em que a provisão penal, então estabelecida, não é conduzida ao conhecimento da pessoa à qual pretende-se aplicar a pena.

A punição é também ineficaz nos casos em que a provisão penal tenha sido conduzida ao conhecimento do indivíduo ao qual se pretende aplicar a pena, contudo, não surtirá efeito algum sobre ele, com respeito a impedi-lo de efetuar o ato que se quer impedir. Mostra-se a seguir alguns exemplos: 1) na infância, quando o homem ainda não atingiu o estado de disposição mental, o qual a lei possua alguma possibilidade de influenciar sua conduta, 2) no caso de insanidade, 3) no caso de intoxicação, como uso de drogas, em que o agente aja contrariamente à sua vontade.

\footnotetext{
${ }^{204}$ A respeito disto cito Bentham em An Introduction to the Principles of Moral and Legislation p. 84: “(...) This may be the case with any thing that is done in the way of precaution against instant calamity, as also with any thing that is done in the exercise of the several sorts of powers necessary to be established in every community, to wit, domestic, judicial, military, and supreme (...)".

${ }^{205}$ Bentham admite que esta última suposição não pode ser verificada de fato, mas apenas vislumbrada.

${ }^{206}$ A respeito disto cito Bentham em An Introduction to the Principles of Moral and Legislation p. 83: “(...) Where it must be inefficacious: where is cannot act so as to prevent the mischief (...)".
} 
Além das situações acima descritas, a punição se faz ineficaz, também, nos casos em que o conjunto de penas não pode ter efeitos em relação ao indivíduo que está em vias de cometer o ato em questão, porque o indivíduo não sabe que o ato se relaciona ao número de penas previstas. Exemplos: 1) no caso da não intencionalidade, em que o indivíduo não pretende efetuar o ato, mas o fará sem intenção, 2) no caso da não consciência, quando o indivíduo sabe que cometerá o ato, porém não sabe quais as circunstâncias materiais que o envolvem, tornando a tendência de produzir mal oculta para ele e 3) no caso de suposições errôneas, em que a partir de certas circunstâncias levadas em conta, o indivíduo acredita que seu ato não produzirá mal ou gerará um bem maior do que o mal que possa causar.

A punição também torna-se ineficaz nos casos em que mesmo que haja uma completa e prevalente influência da lei sobre um agente, alguma outra causa predominante obrigue o indivíduo a praticar tal ato. Por exemplo, nos casos em que os males aos quais o indivíduo tenha que, necessariamente, resistir são extremamente grandes. Isto pode aparecer: 1) nos casos de danos físicos causados pelos poderes da natureza e 2) no caso de um mal ameaçador causado por outro homem (como a partir da sanção moral e religiosa podendo ser maior do que qualquer pena que o legislador possa imprimir).

Por fim, a pena é, ainda, considerada ineficaz, quando a cláusula penal exerce uma influência completa sobre a vontade do agente, porém suas faculdades físicas o impedem de agir de acordo com sua vontade. Ou seja, suas condições são totalmente involuntárias.

c) Casos em que a punição é não proveitosa (não lucrativa) ${ }^{207}$

\footnotetext{
${ }^{207}$ A respeito disto cito Bentham em An Introduction to the Principles of Moral and Legislation p. 83: “(...) Where it is unprofitable, or too expensive: where the mischief it would produce would be greater than what it would prevent (...)".
} 
Quando o mal resultante da punição é maior do que o bem que se deseja auferir dela, a punição torna-se não proveitosa (excessivamente custosa). O mal da punição, neste caso, é maior do que o mal da ofensa, somando-se a ela, sem que um benefício suficiente seja auferido, por influência de algumas circunstâncias. Por exemplo: a) nos casos em que os serviços penais se tornam extremamente onerosos, privando a comunidade de se beneficiar de outros serviços estatais, b) nos casos em que a comunidade não deseja punir determinada ofensa ou determinado ofensor, em uma dada circunstância, da maneira corrente.

d) Casos em que a punição não se faz necessária ${ }^{208}$.

Tais situações são os eventos em que o propósito de colocar um fim a uma determina ação pode ser atingido a uma taxa mais barata do que utilizando a punição legal, como, por exemplo, pela instrução ou pelo terror, informando o entendimento ou pela influência direta na vontade. Estes parecem ser os casos em que alguns disseminam idéias perniciosas no que concerne a questões de dever, quaisquer que sejam os tipos de dever (políticos, morais ou religiosos). Bentham diz, que em casos como este, em havendo necessidade, o governante deve agir sempre com a caneta e não com punição ${ }^{209}$. Isto não impedirá que muitos autores escrevam teorias com conseqüências maléficas à sociedade, mas evitará que os indivíduos tomem tais teorias como verdadeiras.

Tendo em vista os casos em que não cabe aplicação da legislação, pergunta-se, então, onde encontra-se esta linha divisória (entre a legislação e a ética), no que concerne aos

\footnotetext{
${ }^{208}$ A respeito disto cito Bentham em An Introduction to the Principles of Moral and Legislation p. 84: “(...) Where it is needless: where the mischief may be prevented, or cease of itself, without it, that is, at a cheaper rate (...)".

${ }^{209}$ A respeito disto cito Bentham em An Introduction to the Principles of Moral and Legislation p. 83: “(...) But if the sovereign must needs take a part in the controversy, the pen is the proper weapon to combat error with, not the sword (...)".
} 
casos de interação negativa entre indivíduos (abstenção ou não de gerar dor). A resposta até este momento tem sido conduzida com base no critério metodológico do balanço entre prazer e dor. Este mesmo critério ditará em quais destes casos em que a legislação não deve atuar a ética deve ser aplicada ${ }^{210}$.

\footnotetext{
${ }^{210}$ Sobre isto cito Bentham em Uma Introdução aos Princípios da Moral e da Legislação p. 144 item IX: "[...] Where, then, is the line to be drawn? We shall not have far to seek for it. The business is to given an idea of the cases in which ethics ought, and in which legislation ought not (in a direct manner at least) to interfere (...)".
} 


\subsubsection{Solução do Problema: A demarcação da fronteira entre ética e legislação}

Conforme mencionado, se a legislação interfere de alguma forma, deve ser a partir da punição (ou recompensa em casos mais raros) ${ }^{211}$. Os casos em que a sanção política (legislação) não necessita ser aplicada foram discutidos acima (quando a punição é infundada, quando a punição é ineficaz, quando a punição é não proveitosa e quando não há necessidade de punição). Contudo, em alguns destes eventos, em que a legislação não deve interferir, pode-se observar que a ética necessita entrar em cena.

Analisar-se-á, aqui, assim como o autor, todos este casos, para verificar se há espaço para a interferência da ética, ao mesmo tempo em que não há nenhum espaço para a interferência da legislação. Nos episódios em que a punição é infundada (casos em que nenhum mal foi cometido) fica evidente que a interferência restritiva da ética também não é necessária. Isto ocorre porque não há nenhum mal no ato, ou em outros termos, o ato não corresponde a uma ofensa $^{212}$.

Os casos em que a punição se configura como ineficaz devem ser divididos em duas classes: a primeira não diz respeito à natureza do ato, ela refere-se a uma distorção no que concerne ao momento da punição, ou seja, tal pena deveria ser aplicada em outro momento que não o da denúncia (segundo Bentham, este é o típico ex-post-facto law que inclui uma sentença judiciária não abrangida pela lei). Estes atos devem, tanto estar sob a cobertura de coerção legislativa (no futuro), quanto serem vigiados pela ética privada e sanção moral. Em relação ao outro conjunto ou classe de atos aos quais a punição torna-se ineficaz, pode-se dizer que tal

\footnotetext{
${ }^{211}$ A respeito disto cito Bentham em An Introduction to the Principles of Moral and Legislation p. 144 nota I: “(...) I say nothing in this place of reward: because it is only in a few extraordinary cases that it can be applied, and because even where it is applied, it may be doubted, perhaps, whether the application of it can, properly speaking, be termed an act of legislation (...)".

${ }^{212}$ A respeito disto cito Bentham em An Introduction to the Principles of Moral and Legislation p. 144: “(...) In these cases it is evident, that the restrictive interference of ethics would be groundless too (...)".
} 
classe, também, não diz respeito à natureza do ato, mas sim à estranheza das circunstâncias que o acompanham. Estas circunstâncias são de tal natureza que deixam pouco ou nenhum espaço, tanto para a aplicação legal quanto para a influência da ética. Estes são os casos em que o ato é cometido por crianças, loucos ou bêbados ou eventos de não intencionalidade, de não consciência, de suposições errôneas ou de impedimento físico ao exercício da punição. Nestas situações, nem os ditames da legislação ("thunders of law”) (Bentham, 1789 p.145).nem os cochichos (“whispers of morality”) (Bentham, 1789 p.145).da ética ou moralidade são capazes de impedir a ocorrência destes $\operatorname{atos}^{213}$.

Os casos em que as punições são não proveitosas, não lucrativas (ou, em outras palavras, extremamente custosas) constituem o grande campo de interferência da ética, no que concerne ao agir negativo. Quando uma punição é muito onerosa é porque o mal da punição excede o benefício auferido. Como vimos acima, o mal da punição se distingue em quatro campos: a) o mal da coerção, b) o mal da apreensão, c) o mal do sofrimento e d) os males derivados que atingem pessoas que estão em conexão com indivíduos que sofrem as penas acima descritas. Com respeito aos três primeiros tipos de males, pode-se dizer que os indivíduos dividem-se em dois conjuntos: a) pessoas que realmente cometeram ou estiveram prontas a cometer o mal e necessitam ser proibidas de fazê-lo e b) indivíduos que podem ter agido ou ter estado prontos a efetuar outros atos perniciosos, por apresentarem medo de serem envolvidos nos atos proibidos efetuados pelo primeiro conjunto.

Segundo Bentham, somente o primeiro conjunto é pernicioso, e, portanto, deve ser objeto de interferência da ética (regras de ação que estejam de acordo com o princípio da

\footnotetext{
${ }^{213}$ A respeito disto cito Bentham em An Introduction to the Principles of Moral and Legislation p. 145: “(...) It is evident, that in these cases, if the thunders of the law prove impotent, the whispers of simple morality can have but little influence (...)".
} 
utilidade, ou de acordo com a felicidade da maioria). O último conjunto sendo por suposição inofensivo não deve ser objeto da ética, nem tão pouco da legislação.

A punição, então, quando aplicada ao primeiro conjunto de indivíduos, pode ser dita não proveitosa em dois sentidos: a) pela despesa que pode causar e b) pelo perigo de envolver inocentes na condenação designada ao culpado ${ }^{214}$.

O primeiro caso depende de uma proporção entre o mal da punição e o benefício obtido com ela. Este é o evento em que, dada a natureza de uma determinada ofensa, a magnitude da punição supera os ganhos auferidos por ela. Ou seja, estas são situações em que a punição deve ser impedida.

Ainda com respeito a estes casos em que o mal causado pela punição supera o benefício gerado por ela, existem situações particulares em que a punição parece incerta ao infrator, a saber: 1) quando não há suficiente promulgação da lei, 2) devido a circunstâncias particulares em que atuam motivos sedutores e 3) pelo fato de as circunstâncias poderem influenciar a sensibilidade dos indivíduos expostos à ação criminosa.

Nos eventos em que os motivos sedutores são fortes e que a sensibilidade do agente é alterada conforme as circunstâncias nas quais os agentes são expostos, a ofensa será cometida não importa a taxa ou a magnitude da pena. Tal infração poderá ser detectada e punida, mas para propósitos de exemplificação aos demais membros da comunidade (o que constitui o principal objetivo das penalidades) a punição não terá utilidade, uma vez que a utilidade de uma punição depende da diminuição futura dos mesmos casos de delinqüência. Portanto, se esta futura punição depender de detecção que não pareça ameaçadora ou provável, especialmente, aos olhos

\footnotetext{
${ }^{214}$ A respeito disto cito Bentham em An Introduction to the Principles of Moral and Legislation p. 145: “(...) Punishment, then, as applied to delinquency, may be unprofitable in both or either of two ways: 1 . By the expense it would amount to, even supposing the application of it to be confined altogether to delinquency: 2. By the danger there may be of its involving the innocent in the fate designed only for the guilty (...)".
} 
daquele que é arrebatado pelos motivos sedutores, ela não se faz útil (constitui um custo desnecessário ao Estado).

No caso em que penas fossem aplicadas a estes eventos, haveria, então, dois males ocorrendo ao mesmo tempo, um ao lado do outro, quais sejam: o mal da doença (no caso a ofensa) e o mal da dor (no caso a punição), não havendo nenhum proveito em efetuar-se a pena $^{215}$

Há casos em que a punição é considerada não proveitosa ou não lucrativa em virtude de um inocente ser envolvido. Isto pode ocorrer devido à dificuldade de se fixar ou estabelecer a quem a culpa é devida. Este problema ocorre devido a dois fatores: o primeiro refere-se à própria natureza da ação e o segundo diz respeito à qualidade dos homens colocados no governo, ou seja, diz respeito às capacidades que os homens possuem de imputar a culpa. No que concerne à última dificuldade, pode-se dizer que o governante encontrará tanto mais barreiras de imputação da culpa quanto maior sua dificuldade em conseguir lidar com a linguagem. Os atos que impedem a imputação de culpa são difíceis de serem levados para o âmbito da legislação, sem uma complicação verbal ou uma situação que dê margem a interpretações errôneas da lei $^{216}$.

Tendo em vista o exposto, em quase todas as variantes do caso em que a punição não é proveitosa (com exceção do conjunto de indivíduos que podem cometer um crime devido ao conjunto de indivíduos criminosos, conjunto b, citado), a ética, entendida como conjunto de regras de ação capaz de zelar pela felicidade da comunidade, deve ser aplicada. Ou seja, deve ser estimulado, na comunidade, uma negação destes tipos de atos, a partir do estímulo de motivos

\footnotetext{
${ }^{215}$ A respeito disto cito Bentham em An Introduction to the Principles of Moral and Legislation p. 146: “(...) Here then, will be two opposite evils running on at the same time, yet neither of them reducing the quantum of the other: the evil of the disease and the evil of painful and inefficacious remedy (...)".

${ }^{216}$ Conforme mencionado ao longo deste trabalho, Bentham insiste que os legisladores ou homens públicos tomem muito cuidado com a linguagem, pois esta constitui um importante instrumento através do qual muita dor pode ser gerada, quando mal aplicado.
} 
sociais ou a partir da força da sanção moral, fazendo como que os membros de uma sociedade levem em conta o bem estar geral dela, como sendo de seu próprio interesse.

Isto, em outras palavras, é o mesmo que dizer que a ética será aplicada nos casos da interação negativa entre indivíduos, apenas quando o princípio de utilidade não permitir o emprego da legislação. Ou seja, é o princípio de utilidade, através de um balanço de prazer e dor, ou custo benefício, que delimita a fronteira entre a ética e a legislação neste campo (relativo à probidade).

Assim, após a análise dos casos em que não cabe punir, mas apenas aplicar a ética, volta-se aos tipos de ações que os indivíduos podem realizar, para que a fronteira entre a ética e a legislação seja traçada.

Relembrando os tipos de ações dos indivíduos, tem-se: a) ação de um indivíduo para consigo (denominada prudência quando gera mais prazer do que dor), b) ação de um indivíduo para com os outros de maneira positiva (chamada beneficência ou beneficência quando ocasiona mais prazer do que dor) e c) interação entre indivíduos de forma negativa ou abstenção de geração de dor para outros (probidade quando gera mais prazer do que dor).

Pode-se mostrar que o grau em que a ética privada possui necessidade de intervenção da legislação é diferente no que concerne a estes três ramos, devido a um cálculo de prazer e dor (custo benefício) das conseqüencias de colocar-se o aparato legislativo em funcionamento.

Das regras da ética, aquelas que parecem necessitar menos da assistência da legislação são as regras da prudência. Bentham diz que só pode ser por um defeito do entendimento que um indivíduo se descuidará das regras de prudência consigo. Se o agente comete estes erros, isto será devido, apenas, a ele próprio. Com respeito a este assunto, o autor diz que alguns poderiam argumentar que os homens conhecem pouco sobre si e por isso 
precisariam de ajuda. A resposta de Bentham, a esta alegação, argumenta que ninguém conhece mais sobre si do que o próprio agente, ou seja, os legisladores não possuem meios eficientes de saber mais sobre os interesses dos indivíduos do que eles próprios, no que concerne a cuidados individuais tomados por estes agentes (regras da prudência).

Segundo o autor, é apenas com respeito às amplas linhas de conduta nas quais todas as pessoas ou ao menos alguns indivíduos encontram-se envolvidos que o Estado pode ter a pretensão de interferir ${ }^{217}$. Mesmo assim, em muitas dessas ocasiões, a interferência da legislação poderá figurar objeto de disputa, conforme mostrado acima. Em muitos momentos o Estado não deve esperar submissão à sua simples força de sanção. Em outras situações, tudo o que ele tem a fazer é aumentar a eficácia da ética privada dando força e direção à sanção moral, que, obviamente, esteja de acordo com a felicidade da maioria ${ }^{218}$. Bentham argumenta: com qual chance de sucesso poderia o governo extirpar o alcoolismo através do uso da punição legal? o autor mostra que nem todas as torturas que a engenhosidade humana pudesse criar seriam capazes de impedir este vício ${ }^{219}$. Antes que algum progresso fosse feito neste sentido, uma massa muito superior de males seria criada pelo exercício da punição.

A grande dificuldade em efetuar este tipo de punição estaria em tentar obter evidência da ofensa sem espalhar desanimo pelos vínculos de simpatia de todas as famílias, removendo a influência dos motivos sociais, em uma comunidade qualquer.

\footnotetext{
${ }^{217}$ A respeito disto cito Bentham em An Introduction to the Principles of Moral and Legislation p. 146: “(...) It is only with respect to those broad lines of conduct in which all persons, or very large and permanent descriptions of persons, may be in a way to engage, that he can have any pretence for interfering: and even here the propriety of his interference will, in most instances, lie very open to dispute (...) ".

${ }^{218}$ A respeito disto cito Bentham em An Introduction to the Principles of Moral and Legislation p. 146: “(...) All he can hope to do, is to increase the efficacy of private ethics, by giving strength and direction to the influence of the moral sanction (...)”.

${ }^{219}$ A respeito disto cito Bentham em An Introduction to the Principles of Moral and Legislation p. 147: “(...) With what chance of success, for example, would a legislator go about, to extirpate drunkenness an fornication, by dint of legal punishment? Not all the tortures which ingenuity could invent would compass it: and, before he had made any progress worth regarding, such a mass of evil would be produced by the punishment, as would exceed, a thousandfold, the utmost possible mischief of the offense (...)".
} 
De acordo com o autor, tudo que o governo pode fazer contra ofensas desta natureza (relativas à falta de prudência), com algum proveito, em caso de relevância, é sujeitar os agentes que cometem estes atos a uma fina censura, para mantê-los com uma certa sombra de má reputação.

Entretanto, segundo Bentham, em sua época, os legisladores estavam dispostos a interferir o máximo que podiam, no que diz respeito a este ramo do dever (a prudência) ${ }^{220}$. A grande dificuldade, então, seria persuadir os governantes a ficarem limitados a um escopo em que a lei é eficiente ${ }^{221}$, para que paixões e preconceitos não façam com que os homens políticos estreitem a liberdade do sujeito, imprimindo custos à sociedade, muito superiores ao benefício que podem ser auferidos.

O mal deste tipo de interferência é mais particularmente notável no que concerne à religião. A razão é a seguinte: existem alguns erros relativos às crenças nos quais a humanidade está inclinada, pois supõe-se um ser com infinita benevolência que pune aqueles que cometem erros, causando-lhes uma infinidade de tormentos. Uma analogia é feita, pelo autor, com a classe de legisladores. Bentham argumenta, ironicamente, que pela própria posição, os legisladores sempre conseguiriam encontrar a verdade em suas inquisições. $\mathrm{O}$ autor alega que ao invés destes tentarem salvar seu povo do abismo, procurando resguardar o máximo de felicidade da

\footnotetext{
${ }^{220}$ A respeito disto cito Bentham em An Introduction to the Principles of Moral and Legislation p. 147: "(...) It may be observed, that with regard to this branch of duty, legislators have, in general, been disposed to carry their interference full as far as is expedient. The great difficulty here is, to persuade them to confine themselves within bounds (...)".

${ }^{221}$ Sobre isto cito Bentham em Uma Introdução aos Princípios da Moral e da Legislação p. 72-73: “[...] Centenas de pequenas paixões e preconceitos têm-nos conduzido a limitar a liberdade do indivíduo nesta linha, em casos em que ou não se pode esperar proveito algum da punição, ou a vantagem colhida não compensa o dispêndio feito [...]".
} 
comunidade, fazem o contrário, o empurram ainda mais em direção a ele ${ }^{222}$, quando interferem nas regras de prudência.

As regras da probidade (integridade de caráter) são aquelas que mais necessitam de assistência do legislador, conforme mencionado. Existem poucos casos em que o homem público deva punir alguém por auto-ferir-se (campo da prudência), mas ao mesmo tempo, são poucos os casos em que não se pode punir alguém por cometer injúria a um vizinho (apenas os casos enumerados acima).

Com respeito a estas regras, conclui-se que a ética privada depende da existência da legislação, pois, primeiramente, o legislador estabelece quais coisas dirão respeito à propriedade do homem, antes que as regras gerais da ética tenham alguma aplicação. Segundo Bentham, precisamos saber primeiro quais são os ditames da legislação, antes que saibamos quais são os ditames da ética privada, no que tange à probidade. Mesmo nos casos em que não cabe punir, vistos acima, seria necessário um exame do legislador, para que estes fossem assim nomeados e pudessem ser deixados sob o escopo da ética (como quando a punição é não proveitosa).

Então, com respeito à probidade, poder-se-ia dizer que a legislação engloba a ética privada, no sentido que dá espaço para ela existir quando não compensa ser aplicada.

Disto depreende-se que, o princípio de utilidade ("the principles of morals") embasa a criação fictícia da legislação e a partir dos casos em que a legislação não pode existir, devido aos ditames da utilidade, há espaço para a aplicação da ética, através da sanção moral, nos casos de ofensas.

O autor, inclusive, é otimista ${ }^{223}$ em relação aos indivíduos, pois podemos, através da instrução, fazer com que cultivem motivos sociais pelos outros membros da comunidade,

\footnotetext{
${ }^{222}$ A respeito disto cito Bentham em An Introduction to the Principles of Moral and Legislation p. 147: “(...) This being the case, when the sovereign sees his people ready to plunge headlong into an abyss of fire, shall he not stretch out a hand to save them? (...)".
} 
evitando injúrias, ou geração de dor. Contudo, a legislação existe como uma forma de garantir, coercitivamente (de maneira eficiente), as ações de indivíduos que não seguem motivos sociais, ou seja, ela existe para punir ações perniciosas que concorrem com os interesses da comunidade.

Em outras palavras, o princípio da utilidade, explicitado como o grande princípio da moral, no que diz respeito à interação negativa entre indivíduos (probidade quando gera mais prazer do que dor), é aplicado para a construção de uma legislação que apenas deixará espaço para ética quando os custos punição concorrerem com os prejuízos das ofensas, sem que benefícios suficientes sejam auferidos (principalmente nos casos em que a punição é dita não proveitosa).

As regras de beneficência, diferentemente das regras de probibidade, especialmente no que concerne a detalhes, devem ser deixadas sob escopo da ética privada, também por uma questão de eficiência. Em muitos casos, a qualidade benéfica dos atos dependerá, essencialmente, da disposição do agente, isto é: sob o efeito de quais motivos ele encontra-se inclinado a agir, como no caso de motivos sociais como simpatia, amor à amizade ou amor à reputação.

Ações relacionadas à benevolência são aquelas efetuadas de acordo com a livre vontade do indivíduo, não constrangido pelo governo. Contudo, o autor argumenta que o limite da legislação pode ser estendido a este escopo, particularmente, nos casos em que uma pessoa encontra-se em perigo e podemos salvá-la, sem riscos para nós mesmos. Ou seja, os indivíduos estariam moralmente 224 e legalmente obrigados a salvar outro, caso uma determinada situação não ofereça riscos a ele.

\footnotetext{
${ }^{223}$ No que concerne a isto cito Bentham em Déontologie ou Science de la Morale p.100: “(...) [...] Elle a pour objet d'arrêter la parole ou l'action qui infligerait du mal à autrui, et, s'il est possible, de réformer la pensée propre à créer ou à exciter l'action ou la parole, ayant une tendance ou un effet funeste [...].

${ }^{224}$ É relevante entender que esta obrigação moral não possui a força coercitiva da lei. Entretanto, deve-se ter em vista que a sanção moral também é um importante instrumento de coação, para fazer com que as ações dos indivíduos concordem com o princípio de utilidade.
} 
De todo o exposto, conclui-se que a ética privada ensina como cada homem persegue sua própria felicidade, pelos motivos que oferecem a si mesmos, afetando ou não outros indivíduos. No caso de afetar outros indivíduos, pode-se dizer que a ética atuará ou não sozinha, dependendo daquilo que o princípio da utilidade prescreve, em cada situação. A arte da legislação, por outro lado, ensina como um grande número de homens, compondo uma comunidade, podem estar dispostos a perseguir o curso da felicidade de todos, por meio de motivos a serem aplicados pelo legislador, nos casos em que o princípio da utilidade admite sua interferência.

Assim, o espaço da ética ou o campo do agir moral estará restrito, pelo próprio princípio de utilidade (balanço de prazer e dor) às ações que os indivíduos possuem com eles mesmos (prudência), ao agir com o outro a fim de proporcionar prazer (beneficência) e para salvaguardar a felicidade dos indivíduos (probidade) nos casos em que o balanço de prazer e dor indica a não intervenção da lei ou a não punição.

Disto conclui-se que não há diferença de natureza do conteúdo das regras que constam na ética e na legislação. Em última instância é a análise de custo-benefício (prazer e dor) que separa os raios de ação de uma e de outra, sem que critérios adicionais ao princípio de utilidade precisem ser criados pelo autor, para que os limites entre a ética e a legislação sejam estabelecidos. 
V-Conclusão 
Neste trabalho, pretendeu-se reconstruir racionalmente a teoria utilitarista de Jeremy Bentham como forma de entender a primeira concepção do programa de pesquisa do utilitarismo ${ }^{225}$, bem como para examinar o problema das relações e dos limites entre a ética e a legislação. Tencionou-se, portanto, a partir da reconstrução racional do sistema teórico de Jeremy Bentham, verificar qual o espaço que o agir moral, baseado na ética, possui dentro da doutrina deste autor, como forma de solucionar conflitos das interações entre agentes.

A hipótese de solução do problema foi a de que o próprio princípio da utilidade estabelece a linha divisória entre ambos os campos. Ou seja, foi mostrado que é o princípio da utilidade que dita o raio de ação da lei e da ética, assim como seus limites. Viu-se que a colocação do problema sobre a fronteira entre a ética e a legislação, a partir do princípio de utilidade, significou, em última instância, que a solução foi estabelecida com base no critério de balanço entre prazer e dor ou em termos de prazer líquido (em linguagem moderna pode-se dizer custo benefício) das conseqüências de um ato qualquer.

Em outras palavras verificou-se que não há diferença de natureza do conteúdo das regras presentes na ética e na legislação. O que determina a correta aplicação de uma ou de outra refere-se, única e exclusivamente, ao balanço entre prazer e dor das conseqüências das ações que afetam indivíduos. Isto porque, para alguns casos, conforme mostrado, quando a tendência geral do ato é má, torna-se desvantajosa a aplicação de penas, a partir da legislação, restando espaço para as regras da ética, por meio da sanção moral.

Para que se chegasse a esta conclusão, contudo, foi necessário realizar a reconstrução racional da concepção teórica do autor, a partir da abordagem metodológica da Metodologia da Teoria da Ciência [MTC] de Chiappin e utilizando alguns componentes da sistemática dos programas de pesquisa de Lakatos. A metodologia de Lakatos foi menos utilizada

\footnotetext{
${ }^{225}$ Reitera-se que a concepção de Bentham é assumida como sendo a primeira, por hipótese.
} 
do que a de Chiappin, uma vez que não foi reconstruído um programa de pesquisa com várias concepções teóricas pertencentes a ele, mas sim a concepção de um sistema teórico. Não obstante, utilizou-se, em alguns momentos, sua terminologia, por considerar-se, por hipótese, que o sistema teórico de Bentham, provavelmente, constituirá o primeiro do programa de pesquisa do utilitarismo, que se pretende prosseguir como continuação deste trabalho.

Mostrou-se que reconstruir racionalmente a concepção de Bentham, neste trabalho, significou assumir, metodologicamente, que seu sistema teórico pode ser examinado segundo três níveis de análise: a) Metafísico, b) Lógico e c) Histórico. Viu-se que o nível metafísico, denominado núcleo dos programas de pesquisa ou núcleo de uma concepção teórica, partilha de teses ontológicas, epistemológicas e axiológicas, contendo as principais pressuposições da concepção sob investigação, assim como os fins a serem perseguidos pela concepção teórica ou pelo programa de pesquisa. Mostrou-se que o plano da lógica, que se encontra na heurística positiva de um programa de pesquisa, apresenta enfoque na descrição dos instrumentos, métodos, técnicas, critérios e regras para operacionalizar o núcleo metafísico do sistema teórico ou do programa de pesquisa. Este nível foi dividido em metodologia e metametodologia. Considerou-se que o nível da História da Ciência desempenha, também, um papel heurístico, pois sugere componentes no âmbito histórico contribuem na escolha e justificação das concepções teóricas.

Assumindo esta concepção de racionalidade, efetuou-se a reconstrução racional da concepção teórica de Bentham. Em âmbito Metafísico, verificou-se como tese axiológica o objetivo, por parte do autor, de construir um corpo teórico político e moral de caráter científico, baseado em princípios do funcionamento dos indivíduos, que fosse capaz de avaliar, de maneira consistente e justa, as ações dentro de uma sociedade. Como tese epistemológica do autor, considerou-se a tese empirista, de que todo conhecimento provém da experiência. Como decorrência da tese epistemológica do autor, depreendeu-se a tese ontológica que identifica 
prazer, dor e o indivíduo com entidades reais. O modelo de indivíduo deduzido a partir de sua ontologia e epistemologia foi o seguinte: a) o indivíduo dotado da capacidade de experimentar duas sensações reais (prazer e dor) é a entidade ontológica fundamental, para análise política, pois é o único que possui existência na realidade, b) este indivíduo busca o prazer e foge da dor, ou seja, é auto-interessado e c) o indivíduo possui a faculdade intelectual de uma razão que calcula, ele é capaz de fazer cálculos intertemporais, inclusive no que diz respeito às conseqüências das ações.

O nível da Lógica referente à metodologia da reconstrução racional do autor, forneceu um importante aparato na tentativa de estabelecer os limites entre a ética e a legislação. Entre estes recursos metodológicos destaca-se a operacionalização da tese epistemológica do autor. De acordo com ela, duas entidades foram identificadas: as reais e as fictícias ou ficcionais. Expôs-se que as entidades reais são aquelas que possuem existência na realidade das coisas, incluindo substâncias corpóreas, coisas materiais e impressões sensoriais.

As entidades fictícias foram descritas como nomes cuja existência não pode ser atribuída na realidade das coisas. Elas constituiriam, assim, expressões da linguagem que não podem ser reduzidas gramaticalmente a nomes reais, como os substantivos direito, dever, obrigação, lei e ética. Apesar desta separação entre nomes reais e ficcionais, pôde-se dizer que há uma conexão entre ambos os tipos de nomes, pois todo termo ficcional possui uma relação com um termo real, uma vez que é passível de ocasionar conseqüências que se traduzem em termos de nomes reais, como a geração de prazer ou dor.

Por não ser possível reduzir de maneira tradicional (por meio de definições) nomes reais a nomes ficcionais, Bentham utiliza um modo especial de explicação e análise dos nomes ficcionais denominado paráfrase. Neste método a idéia principal é a de que proposições constituem a unidade do significado, as palavras ou termos ficcionais nada significariam fora de 
sentenças. Além disso, este método enuncia a necessidade de fazer como que os termos ficcionais mantenham relação com termos reais como prazer e dor. $\mathrm{O}$ que o autor pretendia com este recurso metodológico era impedir que os termos ficcionais, todos pertencentes ao jargão legal e moral, fossem vistos como verdades prontas e imutáveis. Em outras palavras, o autor, a partir da separação dos nomes entre reais e ficcionais, desejava fazer com que os homens compreendessem que as leis tanto formais (legislação) quanto informais (da ética) não são verdades prontas e acabadas, nem termos naturais que encontramos no mundo.

O princípio de utilidade, entendido como aquele que reconhece que as ações humanas são guiadas pelos sentimentos de prazer e dor, é ele mesmo uma regra que aponta, a todo instante, para que as leis formais e informais sejam formuladas e reformuladas, com vistas a resguardar a maior felicidade possível, dentro de uma comunidade. Ou seja, a formulação do princípio de utilidade, visto como uma regra que aponta para a consideração da importância das conseqüências das ações, vem permitir aos homens que possam transformar e reformar seus hábitos morais e leis formais (sempre quando necessário) com o intuito de garantir uma maneira de interagir que mais preserve a felicidade de todos.

Bentham, por assumir que o princípio de utilidade aponta sempre na direção de resguardar, da melhor forma possível, a felicidade da comunidade, devido ao fato de admitir que uma ação é boa quando pesa para o prazer, coloca este princípio como a norma para julgamento do que é certo e errado.

O que o autor espera, com este princípio de utilidade e seus recursos metodológicos, é garantir a total liberdade dos indivíduos no sentido de realizar todas as reformas necessárias nas regras morais e legais, sempre que o balanço entre prazer e dor apontar esta necessidade. Em outros termos, ele pretende que o mínimo de dor possível seja gerado à comunidade pelas imposições legais e morais. Esta liberdade para modificar regras constitui um aspecto bastante 
interessante do princípio de utilidade. Não obstante, é ela mesma que cria outros problemas, como à impossibilidade de dar garantias a temas como direitos naturais, por exemplo.

É evidente que este princípio acarreta uma série de outras questões polêmicas como se verificou. Em alguns casos ele é visto como um princípio que suprime os interesses da minoria, em outros ele é chamado de um princípio que implica em egoísmo. Contudo, tentou-se apontar algumas saídas para esta problemática.

Neste caminho de tentar estabelecer os limites entre a moral e a legislação verificou-se a importância de outros recursos metodológicos como o estabelecimento do critério do balanço entre prazer e dor, a divisão das sanções em quatro tipos (física, política, moral e religiosa), deixando claro que a sanção física é sempre o fundamento das outras, a análise da intenção como um recurso que só assume importância quando há provas materiais, a análise de motivos para agrupá-los entre aqueles que mais se harmonizam ou se distanciam dos interesses coletivos, o estabelecimento de critérios de punição, entre outros.

Todos estes recursos, conforme explicitados no capítulo segundo, sempre devem ser considerados à luz das conseqüências das ações, pois tanto os homens que julgam ações (moralizadores e legisladores) só possuem acesso à estes elementos. Todos os outros subsídios subjetivistas constituem informações relevantes, apenas e tão somente na medida em que possam ser avaliados objetivamente, ou seja, na medida em que se tenha prova material acerca deles. Sobre isto realizou-se o debate metametodológico com o princípio da simpatia, com a noção de contrato original, bem como efetuou-se análise de algumas relações históricas, em meio às quais, este princípio se originou.

Outros recursos metodológicos como a separação das ações dos indivíduos em três tipos, quais sejam: de um indivíduo para consigo mesmo, de um indivíduo para com outros de forma positiva (buscando gerar prazer) e de um indivíduo para com outros de forma negativa, 
abstendo-se ou não de gerar dor, também constituíram instrumentos fundamentais na tentativa de entender os limites entre a ética e a legislação. Verificou-se que quando um indivíduo age em benefício de si, sua ação é denominada prudente, quando um indivíduo age com o objetivo de gerar prazer para outros sua ação é denominada beneficente (ou chama-se benevolência efetiva positiva), quando age no sentido de abster-se de gerar dor a terceiros denomina-se probidade (ou benevolência efetiva negativa).

Restou claro que tanto a ética quanto a legislação são meios através dos quais tenta-se dar conta destes tipos de ações. Contudo, a partir desta separação das ações, tentou-se responder à seguinte pergunta: com quais destas ações deve ocupar-se a legislação, bem como com quais delas deve ocupar-se a ética?

Para responder a estas questões tornou-se necessário realizar um exame sobre no consiste a ética e a legislação para o autor. Foi visto que o significado de ética, em sentido amplo, para Bentham, traduziu-se em um princípio norteador, das regras de conduta do agir moral, para a produção de mais prazer do que dor, ou seja, este representa um princípio construído, pelos homens, com o objetivo de garantir o maior benefício de todos. A ética, segundo o autor, foi expressa como a arte de governar as ações dos homens para a produção da maior quantidade possível de felicidade em benefício daqueles cujos interesses encontram-se em jogo. Ou seja, mostrou-se que o sentido geral de ética coincide com o próprio significado de princípio de utilidade.

Assim, considerando que o princípio ético coincide com o princípio da utilidade, tentou-se verificar qual o conteúdo que deve constar nas normas do agir moral. Pela análise de seus textos, foi possível concluir que estas regras são nem mais nem menos do que as regras condizentes com o princípio de utilidade, pois uma ação só pode ser dita correta caso gere mais prazer do que dor e só pode ser condenada caso gere mais dor do que prazer, no cômputo geral 
do balanço das conseqüências das ações. Ou seja, os costumes que fazem parte das regras morais devem, também, passar pelo crivo do princípio de utilidade, pois apesar de existirem uma infinidade de sentimentos que nos levam a crer que algo é certo ou errado, estes sentimentos só podem ser instrumentos válidos para condenar a ação de alguém, caso este alguém aja no sentido de gerar dor.

Disto, entendeu-se que não há ações boas ou más em si mesmas, ou motivos de ações bons ou maus em si mesmos, o que existe e deve ser levado em conta são as conseqüências das ações, só estas podem ser ditas boas ou más em si, pois só elas possuem a capacidade de gerar prazer ou dor em um indivíduo. Foi visto que, inclusive, os vícios e virtudes só podem ser assim nomeados de acordo com as conseqüências produzidas por determinada ação, ou conforme a potencialidade que tenham de ocasionar prazer ou dor. Ou seja, o bem moral, foi dito existir, apenas quando a vontade humana é considerada como um instrumento na produção de um bem físico (prazer) ou na abstenção de uma dor.

Desta exposição, concluiu-se que a moral é sujeita, também, ao julgamento proporcionado pelo balanço entre prazer e dor, o que é o mesmo que dizer estar sob os ditames do princípio de utilidade. O campo da moral, para o autor, deve, então, ter seus julgamentos restritos à análise das conseqüências das ações.

Sobre a legislação, viu-se que toda lei coercitiva cria uma ofensa, converte um ato considerado danoso à sociedade em algum tipo de ofensa formal, por meio de um comando positivo ou negativo. Ou seja, a lei dá a qualidade de ofensa a um ato, por meio de uma proibição, impondo obrigação e coerção, a partir da restrição da liberdade do indivíduo. Conforme foi visto, esta restrição ocasiona dor. Da dor gerada pela restrição da liberdade pôde-se depreender a necessidade de dar-se boas razões ou justificativas à lei. Conforme mostrou-se, estas boas razões referem-se à criação de um benefício ou um prazer maior do que um peso ou 
dor para a comunidade. Em outras palavras, pôde-se afirmar que nenhum constrangimento deve ser criado, nenhuma dor deve ser gerada a não ser que haja satisfatórias razões para isso. Ou seja, a dor causada pela elaboração de uma lei só justifica-se quando ocasiona prazeres de maior magnitude.

Neste ponto inseriu-se a separação entre ética e legislação, pois há alguns casos em que não é benéfico para a sociedade a aplicação de penas e a formulação da legislação, de acordo com o balanço entre prazer e dor. Ou seja, foi visto que o próprio princípio da utilidade determina o raio de atuação da ética, legislação e seus limites.

Mostrou-se que o ramo do agir que diz respeito às conseqüências das ações que afetam apenas o indivíduo que age (chamada prudência quando gera mais prazer do que dor) é restrito ao campo do agir moral, pois, ninguém possui mais informações sobre aquilo que gera prazer ou dor a um indivíduo, do que ele próprio. Ou seja, não há porque haver interferência legal nesta área, pois o legislador não possui a precisão de elementos necessária para entender aquilo que dá prazer ou que gera dor a um indivíduo.

Foi explicitado que, assim, que a legislação não deve ocupar-se deste ramo ético, uma vez que a felicidade dos indivíduos (que compõem uma comunidade) não sofre risco de ser diminuída, a não ser que se considere o indivíduo que comete mal a si mesmo. Contudo, mesmo este indivíduo, quando pratica este tipo de ação, não deve constituir foco da lei, uma vez que esta não possui mais informações sobre ele do que ele próprio. Além disso, foi argumentado que a ação coercitiva do governo, nestes casos, pode instaurar um sentimento de perseguição aos costumes sociais, tendo a possibilidade de causar danos, como a redução dos motivos sociais nos indivíduos.

Ou seja, nos assuntos em que não há interação entre indivíduos (chamados área da prudência) a aplicação do princípio de utilidade ou efetuação de um cálculo de prazer e dor 
(custo benefício em linguagem contemporânea) aponta para a interferência, apenas, da ética, a partir da sanção moral. Contudo, reitera-se que esta interferência da ética também é feita a partir do balanço entre prazer e dor, a partir da aplicação do princípio de utilidade.

No que tange ao segundo tipo de ação, a saber: a beneficência ou o agir para com outros indivíduos no sentido de gerar prazer, pôde-se dizer que este campo fica circunscrito, especialmente, ao escopo da ética. Isto porque, conforme mostrou-se, a qualidade benéfica dos atos depende, essencialmente, da livre disposição do agente não constrangido pelo governo. A atuação da legislação poderia ser estendida a este tipo de ação, particularmente, nos casos em que uma pessoa encontra-se em perigo e é possível, sem riscos para nós mesmos. É o princípio de utilidade que restringe, novamente, a atuação legal, pois nos casos de beneficência o balanço entre prazer e dor aponta para a intervenção, principalmente, da ética.

Concluiu-se, desta forma, que o grande campo de interferência da legislação referese, à probidade, ou em outros termos, à forma de agir que impede a geração de injúrias ou dor para com membros da comunidade. As leis interferem nesta área, pois apresentam o meio mais eficiente de impedir a geração de danos, a saber: a punição legal. Contudo, mesmo nestes casos verificou-se espaço para atuação da ética. Esta oportunidade de aplicação da ética, nos casos relativos ao agir negativo, ocorre, então, quando não for benéfica a aplicação da legislação. Somente nas circunstâncias em que a imputação de penas a determinada transgressão for mais dolorosa do que a vantagem que ocasiona, há espaço para a ética. Mais uma vez é o princípio de utilidade, através do balanço entre prazer e dor ou custo e benefício, que impõe os limites entre a atuação legal e da ética Conforme visto, o caso em que não cabe punir, mas apenas aplicar a ética é chamado, por Bentham, não proveitoso (ou não lucrativo). Este caso ocorre quando o mal resultante da punição (custo) é maior do que o bem (benefício) que se deseja auferir dela. 
Apenas nestes casos, no que concerne ao agir negativo, a ética, entendida como conjunto de regras de ação capaz de zelar pela felicidade da comunidade, deve ser aplicada. Ou seja, deve ser estimulada, na comunidade, uma negação destes tipos de atos, instigando-se o aumento de motivos sociais ou a partir da força da sanção moral, fazendo com que os membros de uma sociedade levem em conta o bem estar geral dela. Desta forma, também nos casos relativos à geração de dor, a aplicação do princípio de utilidade determina o campo de interferência da legislação e da ética.

Da análise destes três tipos de ação foi possível concluir que aquilo que determinará a influência da ética ou da legislação, como forma de solucionar problemas ou dores causadas por indivíduos será, em todos os casos, o princípio de utilidade ou balanço entre prazer e dor. A própria concepção de ética e legislação mostra que não há diferença de natureza do conteúdo de suas regras. Ou seja, tanto as regras morais quanto as regras legais devem passar por um exame de custo e benefício social para que produzam razões aceitáveis para sua existência.

Foi visto, neste trabalho, também, que os indivíduos não possuem obrigações morais como o constrangimento que as leis formais impõem, a partir da punição. Isto porque, de acordo com o modelo de indivíduo, traçado no capítulo segundo, os únicos interesses, para praticar a salvaguarda de outros, que uma pessoa pode encontrar, como motivos adequados, são seus próprios interesses. Não obstante, há a reprovação ou sanção moral que membros da comunidade podem efetuar às ações consideradas perniciosas à sociedade. Em outros termos, é possível afirmar que apesar de não possuir força coercitiva como as leis, a ética também possui um instrumento capaz de constranger as ações dos indivíduos, a partir da geração de dor. Ou seja, existem, no agir moral, regras informais não legais, com algum poder de coação, capazes de produzir prazer ou dor em indivíduos, conforme suas ações estejam ou não de acordo com o princípio de utilidade. 
Além disso, foi mostrado que não existe nenhuma ocasião em que uma pessoa não tenha alguns motivos para promover a felicidade de uma outra, seja por motivos sociais ou motivos semi-sociais. Um bom motivo para agir de acordo com os interesses da comunidade, conforme expresso no capítulo terceiro, refere-se ao fato de que age mais de acordo com o princípio da utilidade aquele que leva em conta, em seus próprios interesses, os interesses de outros, uma vez que gera mais prazer, no cômputo geral, aquele que pratica a probidade ou beneficência para com os outros indivíduos.

Desta exposição conclui-se que o estabelecimento de limites entre a ética e a legislação ocorre por meio de um balanço entre prazer e dor das conseqüências das ações. É o próprio princípio de utilidade que determina quando a ética deve ser aplicada e quando a legislação deve ser empregada, para solucionar situações que ocasionam dor em uma comunidade.

Em outros termos, é possível concluir que não há diferença de natureza do conteúdo presente nas regras da ética e da legislação, pois os preceitos da ética devem estar de acordo com o princípio de utilidade, assim como as regras da legislação. Da mesma forma, os limites entre um campo e outro é estabelecido pelo princípio de utilidade ou cálculo de prazer e dor das conseqüências das ações.

Com o uso dos recursos metodológicos do autor, foi possível concluir que todos os campos em que o princípio de utilidade aponta para a não interferência da legislação correspondem ao ramo da ação que afeta apenas quem age, ao campo da ação que afeta positivamente outros indivíduos e ao ramo do agir negativo, nos casos em que a punição se torna não proveitosa. 


\section{Referências Bibliográficas}

Obras de Bentham em The Works of Jeremy Bentham ${ }^{226}$

A Fragment on Government. Edinburgh: Thomess Press, 1843.

A Table of the Springs of Action. Edinburgh: Thomess Press, 1843.

An Introduction to the Principles of Moral and Legislation. Edinburgh: Thomess Press, 1843.

Anarchical Fallacies. Edinburgh: Thomess Press, 1843

Constitutional Code. Edinburgh: Thomess Press, 1843

Defence of Usury. Edinburgh: Thomess Press, 1843.

Essay on Language. Edinburgh: Thomess Press, 1843

Essay on Logic. Edinburgh: Thomess Press, 1843

\footnotetext{
${ }^{226}$ Note que nas citações do corpo do texto tentei preservar a data da primeira publicação dos escritos do autor. Quando não tive acesso à data da primeira publicação, utilizei a data desta edição de 1843.
} 
On the Liberty of the Press, and Public Discussion. Edinburgh: Thomess Press, 1843

Plan of Parliamentary Reform Bill. Edinburgh: Thomess Press, 1843

Principles of Civil Code. Edinburgh: Thomess Press, 1843

Principles of Penal Law. Edinburgh: Thomess Press, 1843

Principles of the Civil Law. Edinburgh: Thomess Press, 1843

The Books offallacies, From Unfinished Papers. Edinburgh: Thomess Press, 1843

The Promulgation of Laws. Edinburgh: Thomess Press, 1843

The Rationale of Reward. Edinburgh: Thomess Press, 1843

Tracts on Poor Laws and Pauper Management. Edinburgh: Thomess Press, 1843

\section{Obras de Bentham em outras edições}

Bentham 's Theory of Fictions. In Ck Ogdeon. Londres: Routledge, 2000. 
Déontologie, ou Science de la morale, 1834. Disponível em: http://classiques.uqac.ca/classiques/bentham jeremy/deontologie tome 1/deontologie t1.ht $\underline{m l}$.

Uma Introdução aos Princípios da Moral e da Legislação. São Paulo: Abril Cultural, 1974.

\section{Comentadores}

Bendit M. T. - The Public Interest. In Philosophy and Public Affairs, Vol. 2, No 3. (Spring, 1973), 291-311.

Benn A. W. - The History of English Rationalism in The Nineteenth Century. Vol I. Longmans, Greeen, And Co., 1906.

Bhikhu Parekh - Critical Assesment. "Dinwiddy J.R." - Bentham on Private Ethics and the Principle of Utility, 1993.

Broome, J. - Utility, in Economics and Philosophy, 7, 1991.Deontology and Economics, in Economics and Philosophy, 8, 1992.

Burne P.- Bentham and The Utilitarian Principle. In Mind, New Series, Vol. 58, No. 231, (Jul., 1949), 367-368. 
Collard D. - Research on Well Being: Some Advice from Jeremy Bentham. In Wed Working 02.

Daves A. - Jeremy Bentham (1748-1832): The Utilitarian Foundations of Collectivism. Libertarian Heritage $n^{\circ}$ 15, 1995.

Drapne T. - An Introduction to Jeremy's Bentham Theory of Punishment. Journal of Bentham Studies, n5, 2002.

Fuller C. - Primeiro e mais Antigo Constitucional da Europa: Bentham's Contact with portuguese liberarls 1820-23. Journal of Bentham Studies, $\mathrm{n}^{\circ} 3$.

Goldworth A. - Bentham's Concept of Pleasure: Its Relation to Fictitious Terms. In Ethics, Vol. 82 No 4 (Jul., 1972), 334-343.

Guidi M. E. L. - Pain and Human Action: Locke to Bentham. Journal of Bentham Studies, $n^{\circ} 3$.

James M. - Public Interest and Majority Rule in Bentham's Democratic Theory. In Political Theory, Vol 9, No 1 (Feb., 1981), 49-64.

Hart H.L.A. -Essays on Bentham: Studies in Jurisprudence and Political Theory. Oxford University Press, 1982. 
Harworth L.- Autonomy and Utility. In Ethics, Vol. 95, No 1. (Oct., 1984), p. 5-19.

Hazlitt H. - The Foundations of Morality. Disponível em: e-text: www. hazlitt.org

Henry H. - Pleasure as the End. In The Foundations of Morality, 1964.

Hoogensen G. - Bentham's International Manuscripts Versus The Published "Works". In Journal of Bentham Studies, No 2 (2001).

McNaughton R. - A Metrical Concept of Happiness. In Philosophy and Phenomenological Research, Vol. 14, No 2. (Dec., 1953), 172-183.

Mill J. S. - Bentham. London and Westminster Review, Aug. 1838, revised in 1859.

Mill J. S. - Utilitarianism. London University Press, 1861.

Milo D. R. - Bentham's Principles. In Ethics Vol. 84. No 2. (Jan. 1974), 128-139.

Mogin P. \& Sigot N. - Halévy's Bentham is Bentham. In Philosophy , 74 (1999).

Sen, A. - Utility - Ideas and Terminology”, in Economics and Philosophy, 7, 1991.

Sidgwick H. - Bentham and Benthamism in Politics and Ethics. The Fortnightly Review, 21, January - June1877, p. 627-652. 
Singer G. M. - Actual Consequences of Utilitarianism. In Mind, New Series, Vol. 86, No. 341 (Jan., 1977), p. 67-77.

Skinner, A. - Adam Smith: Ethics and Self-Love, in Jones, P. e Skinner, A. (orgs.) Adam Smith Reviewed, Edinburgh University Press, 1992.

Smith, A. - The Theory of Moral Sentiments (1759). The Glasgow Edition of the Works and Correspondence of Adam Smith, Oxford University Press, 1976.

Wilson, T. - Sympathy and Self-interest, in Skinner \& Wilson (eds) The Market and the State, Oxford University Press, 1976.

Warke T. - A Reconstruction of Classical Utilitarianism. Journal of Bentham Studies, $\mathrm{n}^{\circ} 3$, 2000.

Watikin P. C. - Jeremy and Samuel Bentham - The Private and the Public. Journal of Bentham Studies, n5, 2002. 


\section{Bibliografia Geral}

Aristóteles - Ética a Nicômaco. São Paulo: Abril Cultural, 1974.

Chiappin J.R.N. - Racionalidade, Decisão, Solução de Problemas e o Programa de Pesquisa Racionalista. Ciência e Filosofia nº 5 p. 155-219, 1996.

Chiappin J.R.N. - Racionalidade, Decisão e Solução de Problemas e a Reconstrução Racional do Programa de Pesquisa sobre o Racionalismo Clássico, em Manuscritos, 2000.

Chiappin J.R.N. - Notas de Aula.

Descartes R. - Meditações. São Paulo: Abril Cultural, 1974.

Hume D. - Investigações sobre o conhecimento humano. São Paulo: Abril Cultural, 1974.

Johnson O. A. - Ethics. Harcourt Brace College Publishers. Orlando, 1986

Lakatos I. - Methodology of Scientific Research Programs. Criticism and the Growth of Knowledge. Edited by Imre Lakatos and Alan Musgrave. Cambridge University Press, 1970.

Lakatos I. - On Popperian Historyograph. Mathematics, science and epistemology Volume 2. Edited by Jonh Worral and Grgory Currie. Cambridge University Press, 1978. 
Lakatos I. - The Problem of Appraising Scientific Theories. Mathematics, science and epistemology Volume 2. Edited by Jonh Worral and Grgory Currie. Cambridge University Press, 1978.

Lakatos I. - The Social Responsibility of Science. Mathematics, science and epistemology Volume 2. Edited by Jonh Worral and Grgory Currie. Cambridge University Press, 1978.

Laranjeiras C. C. - O Programa de Pesquisa de Ludwig Boltzmanm para a Mecânica Estatística Uma Reconstrução Racional. Tese de Doutorado. São Paulo, 2002.

Leister A.C. - Social Choice vs Public Choice. Tese de Doutorado. São Paulo, 2005. 